Florida International University FIU Digital Commons

$11-26-2001$

\title{
Mountain lake colony pinewood estate garden historic preservation
}

Elisabeth Matthies Barón

Florida International University

DOI: $10.25148 /$ etd.FI14050448

Follow this and additional works at: https://digitalcommons.fiu.edu/etd

Part of the Landscape Architecture Commons

\section{Recommended Citation}

Barón, Elisabeth Matthies, "Mountain lake colony pinewood estate garden historic preservation" (2001). FIU Electronic Theses and Dissertations. 1427.

https://digitalcommons.fiu.edu/etd/1427

This work is brought to you for free and open access by the University Graduate School at FIU Digital Commons. It has been accepted for inclusion in FIU Electronic Theses and Dissertations by an authorized administrator of FIU Digital Commons. For more information, please contact dcc@fiu.edu. 
FLORIDA INTERNATIONAL UNIVERSITY

Miami, Florida

\author{
MOUNTAIN LAKE COLONY \\ PINEWOOD ESTATE GARDEN \\ HISTORIC PRESERVATION
}

A thesis submitted in partial fulfillment of the

requirements for the degree of

MASTER OF LANDSCAPE ARCHITECTURE

By

Elisabeth Matthies Barón

2001 
To: Dean Juan Antonio Bueno

School of Architecture

This thesis, written by Elisabeth Matthies Barón, and entitled Mountain Lake Colony Pinewood Garden Historic Preservation, having been approved in respect to style and intellectual content, is referred to you for judgment.

We have read this thesis and recommend that it be approved.
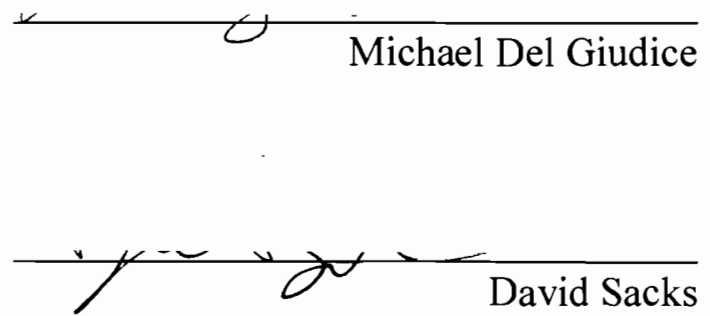

Dr. Esra O/denerol, Major Professor

Date of Defense: November 26, 2001

The thesis of Elisabeth Matthies Barón is approved.

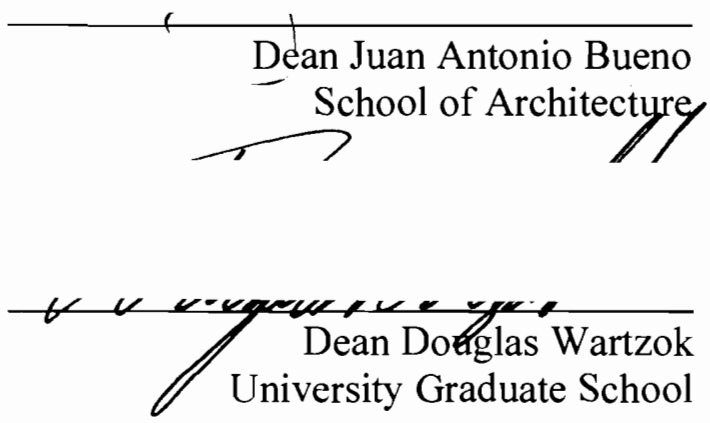

Florida International University, 2001 
(C) Copyright 2001 by Elisabeth Matthies Barón

All rights reserved.

iii 


\section{DEDICATION}

This thesis is dedicated to my loving husband, Luis Fernando, who has contributed much inspiration, thought and support in my writing this thesis, and to my children, Valentina, Diego and Adriana. 


\section{ACKNOWLEDGMENTS}

I wish to thank the members of my committee, Michael Del Giudice, David Sacks and Esra Ozdenerol, for their support, encouragement, and leadership. Their direction has been respected and appreciated. I wish to particularly thank Esra Ozdenerol. She has been involved with this project from day one. She has encouraged me to work harder than I ever thought I could, and all along has been extremely supportive. I appreciate her direction and, most of all, her enthusiasm. 


\title{
ABSTRACT OF THE THESIS \\ MOUNTAIN LAKE COLONY PINEWOOD ESTATE GARDEN \\ HISTORIC PRESERVATION
}

by

\author{
Elisabeth Matthies Barón \\ Florida International University, 2001 \\ Miami, Florida \\ Esra Ozdenerol, Major Professor
}

Pinewood Estate is a significant resource in the history of the theory and practice of landscape architecture. The purpose of this thesis is to provide a landscape plan to restore the Pinewood Estate to its historic integrity in order to retain and reflect its past.

In order to determine the criteria used to establish how and to what period the estate should be restored to, the Secretary of the Interior's Guidelines for the Treatment of Cultural Landscapes was followed. This process involved documenting the existing conditions of the estate. Site inventory and analysis and onsite interviews were conducted. Natural and cultural resources were evaluated.

As a case study, McKee Botanical Garden was analyzed and evaluated. The comparison of this case study served as a guideline to determine the best practice for the historical preservation of the estate.

Despite the changes in the landscape at Pinewood Estate over the past seventy years, the garden today still retains William Lyman Phillips design criteria. For the garden to continue to keep its historic fabric, rehabilitation was selected to allow for improvements that make possible efficient contemporary use of the estate. 
CHAPTER 1 1

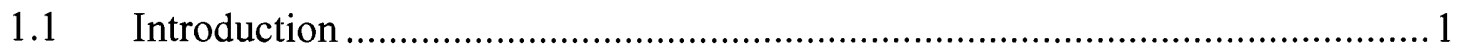

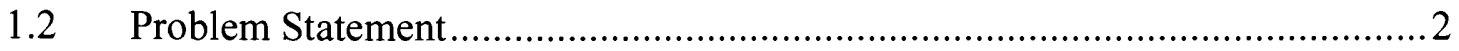

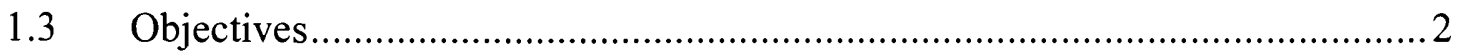

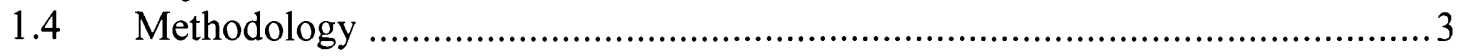

CHAPTER 2 5

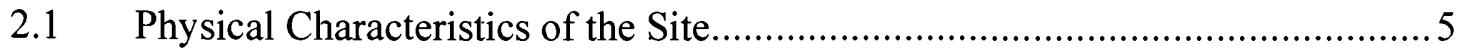

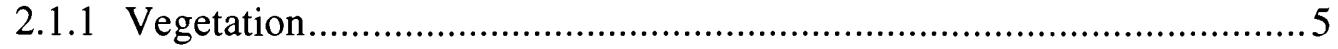

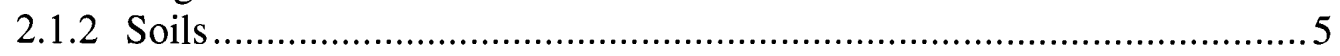

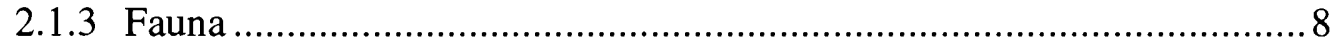

2.2 Overview of the Mountain Lake Development: Geographical Context, Social and Culture History ............................................................................... 10

2.2.1 Ownership, occupancy and development ..................................... 12

$\begin{array}{lr}\text { CHAPTER } 3 & 17\end{array}$

3.1 Olmsted Brothers Design Approach ....................................................... 17

3.2 William L. Phillips Design Approach........................................................ 18

3.2.1 Design criteria for Pinewood Estate ................................................ 18

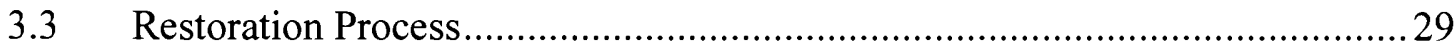

3.3.1 Rudy Favretti Master Restoration Plan ............................................. 33

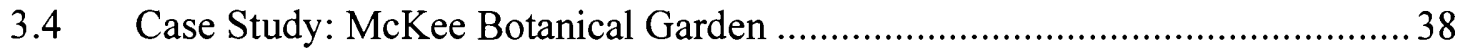

3.4.1 Site and Period of Significance ........................................................ 40

CHAPTER $4 \quad \mathbf{4 3}$

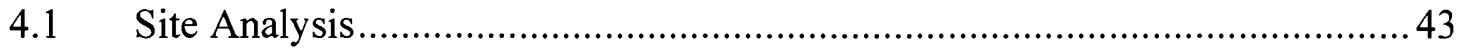

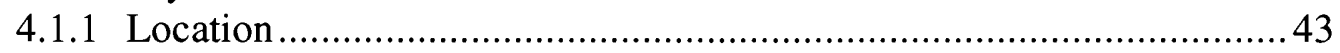

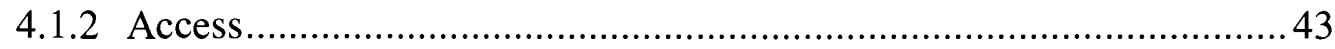

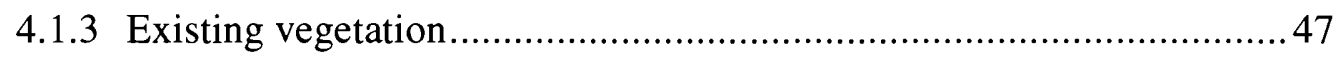

CHAPTER 5 51

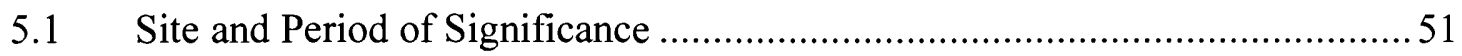

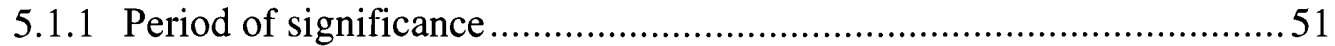

5.1.2 Recommended Treatment...................................................... 52

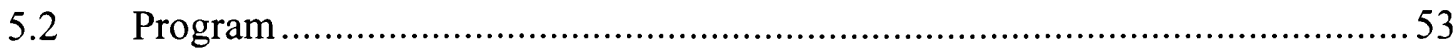

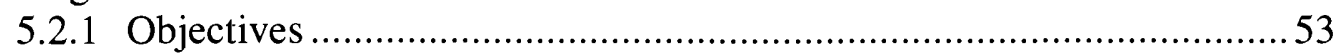

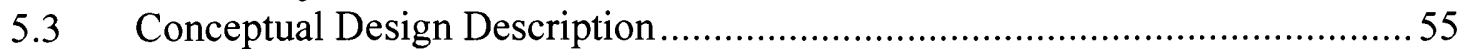

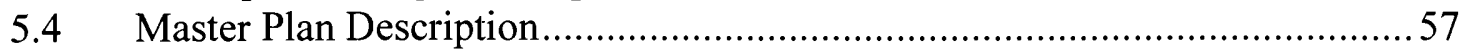

$\begin{array}{lr}\text { CONCLUSION } & 69\end{array}$

REFERENCES

$\begin{array}{lr}\text { APPENDICES } & \mathbf{7 5}\end{array}$ 


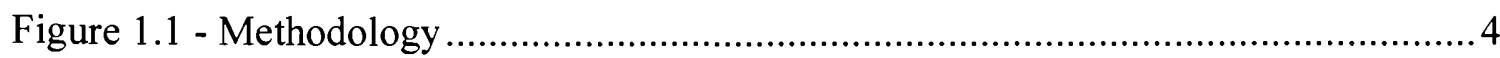

Figure 2.1 - Presettlement range of the long-leaf pine ecosystem ................................ 6

Figure 2.2 - Existing longleaf pines according to William L. Phillips Planting Plan \#523 7

Figure 2.3 - Distribution of high pine clayhill and sandhill in Florida ...........................

Figure 2.4 - Preliminary Plan Mountain Lake Colony, 1927 ...................................... 13

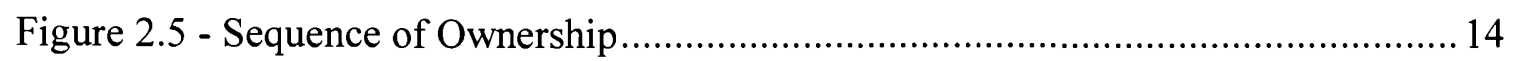

Figure 3.1 - William L. Phillips Conceptual Design Diagram .....................................20

Figure 3.2 - Historic Overview of William L. Phillips Design Ideas ............................22

Figure 3.3 - Comparison of past and present views of the west lawn ...........................24

Figure 3.4 - Site Analysis based on William L. Phillips Planting Plan \#523 .................. 25

Figure 3.5 - Comparison of past and present views from the pond .............................26

Figure 3.6 - Comparison of past and present views of the Frog fountain ......................2 27

Figure 3.7 - Comparison of past and present views of the Moongate garden ................. 28

Figure 3.8 - William L. Phillips Planting Plan \# 523 …............................................ 30

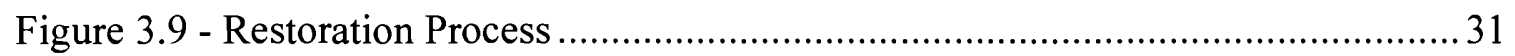

Figure 3.10 - Rudy Favretti's Essence of Olmsted Plan................................................ 34

Figure 3.11 - Rudy Favretti's Restoration Plan........................................................ 35

Figure 3.12 - Connection to Bok Tower Gardens Designed by Rudy Favretti ................ 37

Figure 3.13 - MacKee Botanical Garden Master Plan ............................................... 42

Figure 4.1 - Florida Location Map...................................................................... 44

Figure 4.2 - Access Map to Bok Tower Gardens and Pinewood Estate ......................... 45 


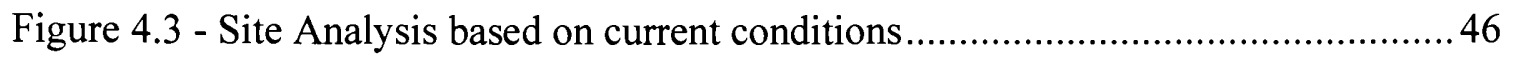

Figure 4.4 - Comparison of past and present views on the east side of the house ............48

Figure 4.5 - Overlay of current conditions compared to 1931 Plan................................50

Figure 5.1 - Conceptual Design Diagram .............................................................. 56

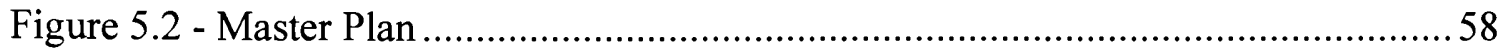

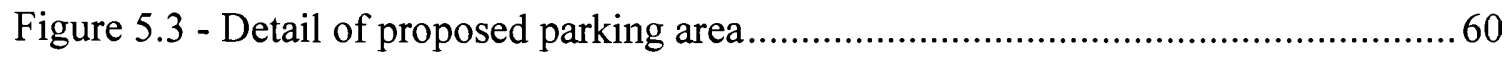

Figure 5.4 - Service entrance with handicapped parking area....................................62

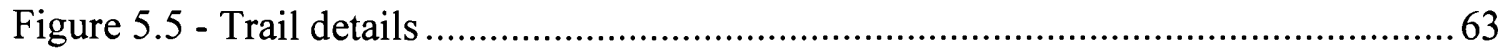

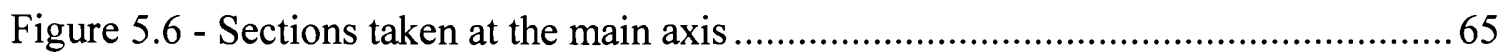

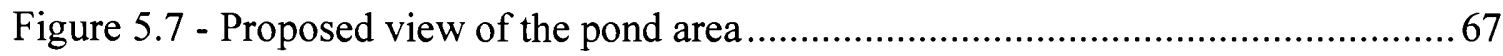

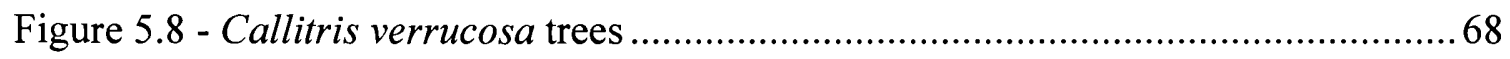




\section{CHAPTER 1}

\section{I.1 Introduction}

The purpose of this thesis is to design Pinewood Estate's garden referring to its history. This research will evaluate the integrity and the current conditions, and select a treatment restoration or rehabilitation that best serves to protect the estate's cultural landscapes. The ultimate goal is to ensure that visitors connect to its past and educate them with its history.

Significant with its history and landscape design, Pinewood Estate is the only remaining William L. Phillips garden open to the public (Favretti 1990). Pinewood Estate is part of Bok Tower Gardens Foundation, Inc., located in Mountain Lake Colony, Polk County, Florida. Charles Austin Buck, vice president of Bethlehem Iron Company, purchased the property in 1929 from the Mountain Lake Colony (Caldwell 1984).

In 1929, Charles Austin Buck hired William Lyman Phillips, who was the local representative in Lake Wales for the landscape architectural firm of Frederick Law Olmsted Jr., to work on the Pinewood property. Phillips, who designed many gardens for winter estates in Mountain Lake Colony, Florida, was involved from the beginning in site planning, designing, building, and planting of the garden (Spain 1991). On December 12, 1985, the estate was listed, under the name of "El Retiro," in the National Register of Historic Places, the official list of culturally significant historic resources in the United States (Spain 1991). 


\subsection{Problem Statement}

When the Bok Tower Foundation acquired the estate in the seventies, much of the original vegetation was no longer there. The last two owners had much less interest in the garden than Charles A. Buck, who was a knowledgeable and a dedicated horticulturist (Wallace 1991). Although the estate's garden has been partially restored, there are still many features missing from William Lyman Phillips' design.

The garden has evolved over time from a sunny landscape of native longleaf pines to an environment of mature oaks trees, which changes its character to largely a shade garden. In addition, the function of the estate has changed, from a private residence to a public garden. It was a winter playground for a very limited number of people with unlimited budget. Today a limited number of people visit the garden. The grounds can only be visited as part of a tour and are closed during the summer time. Maintenance and the change in use play a crucial role in the design decision Therefore, this thesis addresses new design criteria necessary to adapt to those changes and preserve its history.

\subsection{Objectives}

The purpose of this research is to provide a landscape plan to restore the Pinewood Estate to its historic integrity to retain and reflect its past.

1. The primary goal of this restoration is to retain and preserve the Mediterranean Revival style composed of Moorish, English, and Italian Renaissance features used in the design of the garden. Each style is significant to a particular period and is still present in the garden today. Guidelines are proposed to determine how and to what period the estate should be restored. 
2. Improvements for efficient contemporary use of the estate are established in this restoration, which will increase the probability of the garden's continued maintenance.

3. This thesis utilized William L. Phillips' design as a basis for evaluating all inventory and analysis. Although previous efforts have been undertaken, the estate has been only partially restored. As a result, to accomplish a successful restoration plan that reflects William Lyman Phillips' design, there has to be a balance between historic continuity and adaptations to meet current needs for the property to survive. In addition, any element that is not part of the Phillips design, or an adaptation to facilitate contemporary use, should be removed.

\subsection{Methodology}

The methodology used in this thesis followed three steps, as seen in Figure 1.1, in order to come up with a criterion in how and what period the garden such be restored to.

First, extensive site related research was conducted. Existing conditions of the estate were documented in the process of site inventory and analysis. Onsite interviews were conducted and relevant natural and cultural resources were evaluated.

Previous restoration efforts were examined. Finally, the treatment to be used was established by following the Secretary of the Interior's Guidelines for the Treatment of Cultural Landscapes (National Park Service 1996) complemented with a case study. The recently restored McKee Botanical Garden in Vero Beach, Florida, designed by William L. Phillips and Winton H. Reinsmith, was analyzed and evaluated to establish design guidelines and determine the best practice for the historical preservation of the estate. 


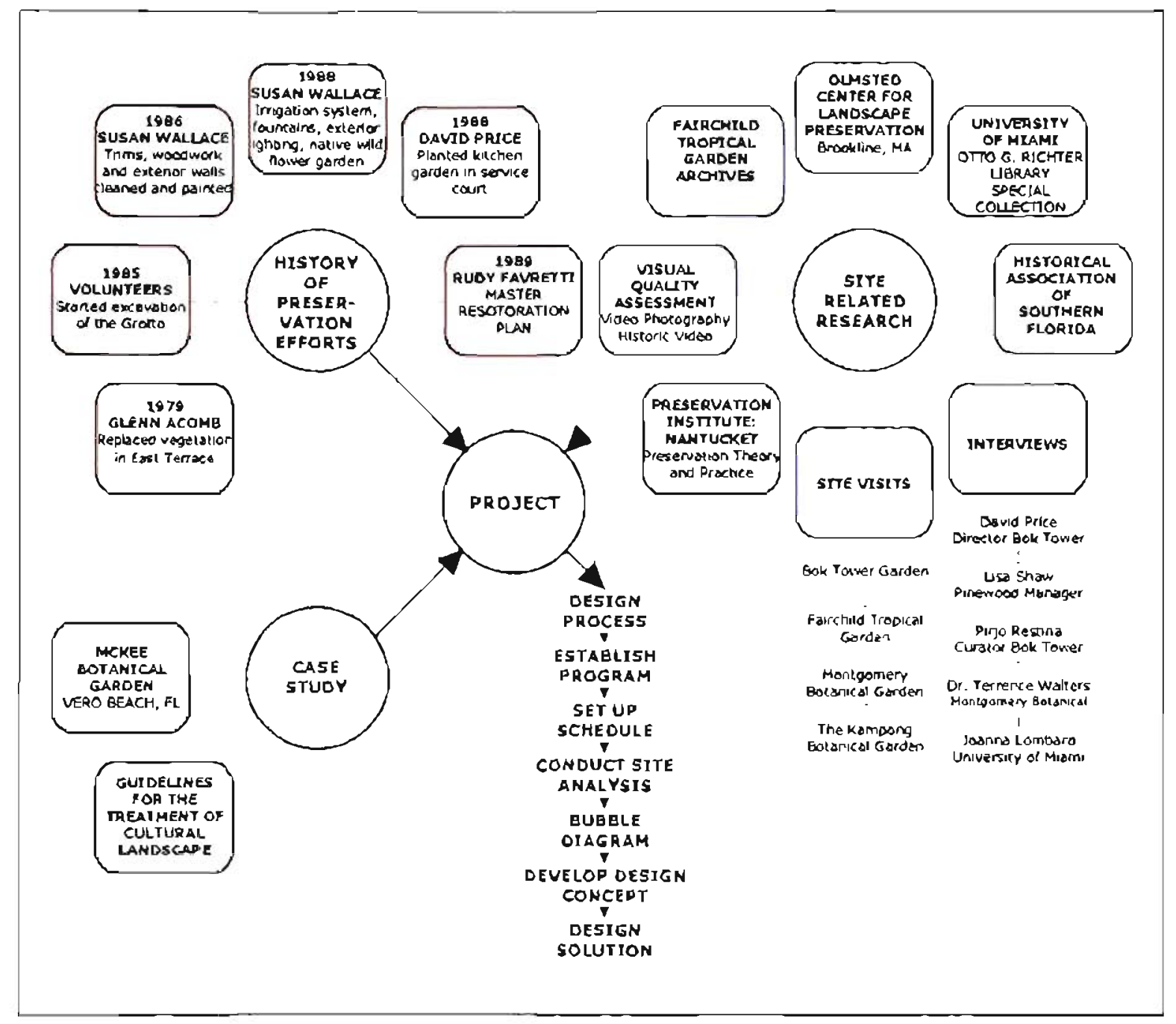

Figure 1,1 - Methodology 


\section{CHAPTER 2}

\subsection{Physical Characteristics of the Site}

\subsubsection{Vegetation}

The Mountain Lake Colony occupies an area of Central Florida that was a longleaf pine/sand hill forest community. The open overstory was formed by longleaf pine and turkey oak, with a dense ground cover of wildflowers, perennial grasses such as wiregrass, and a sparse understory of woody shrubs (Myers and Ewel 1990).

Longleaf pines (Pinus palustris) can live for 500 years. They are fire tolerant. Their existence depends on fire every 3 to 5 years. Historically, the longleaf pine was one of the most important tree species in the Southeastern U.S. forest community, as indicated in Figure 2.1. Unfortunately, only three percent of the longleaf pines remain today as a result of timbering practices (Myers and Ewel 1990).

The creation of Mountain Lake Colony resulted in further modification to the longleaf pine ecosystem with the development of citrus grove private estates, and a golf course. Today, only a few longleaf pines remain within the Colony limits. Most of the existing longleaf pines found on Pinewood were incorporated in the planting plan of William L. Phillips, as seen in Figure 2.2.

\subsubsection{Soils}

The soils of the longleaf pine ecosystem are mostly droughty, coarse drained sands, fertile, calcareous, phosphatic sandy clays, and loamy sands underlain by clays. 


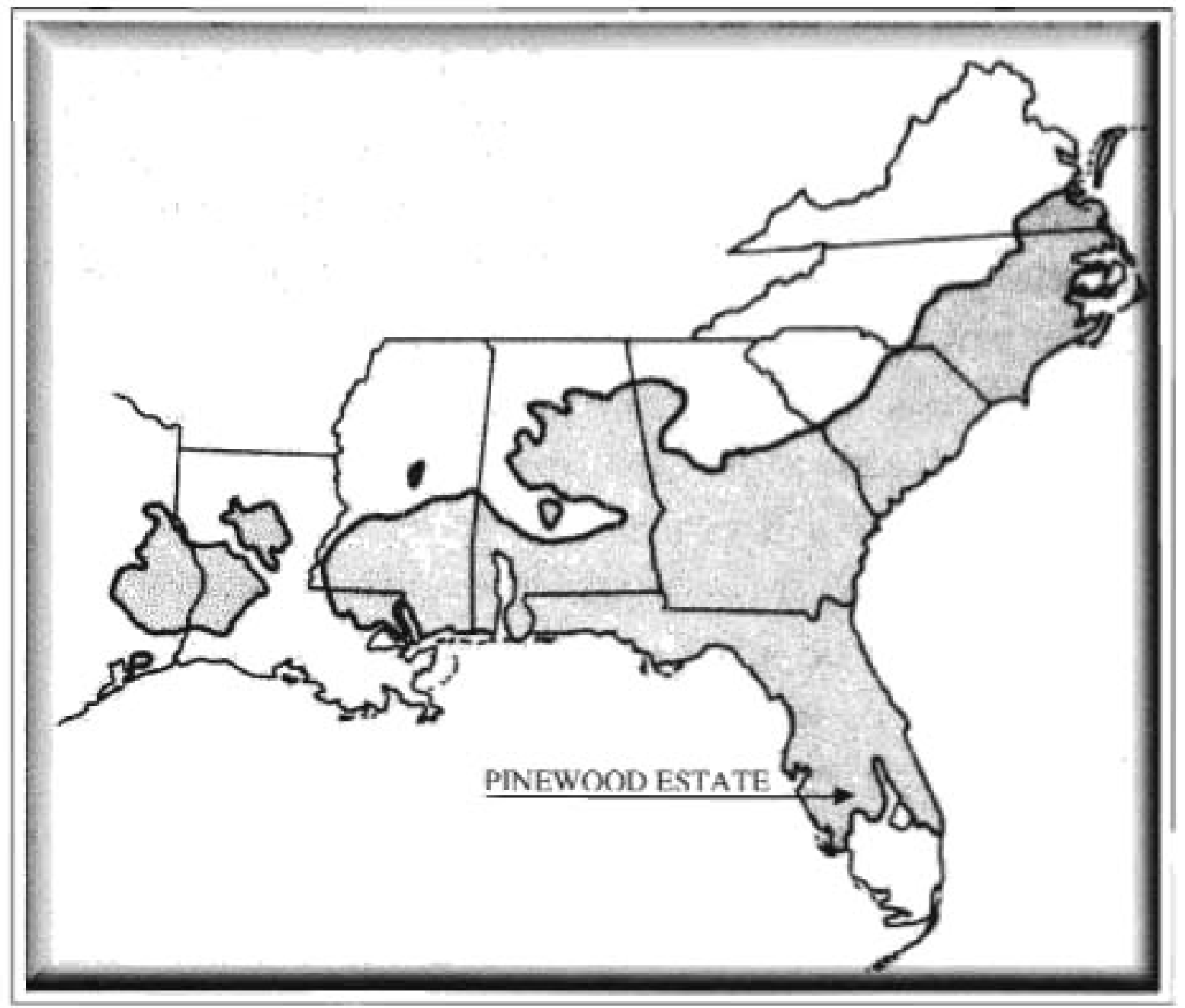

Figure 2.1 - Presettlement range of the long-leaf pine ecosystem Source: Ecosystems of Florida. Meyer and Ewel. 1990 


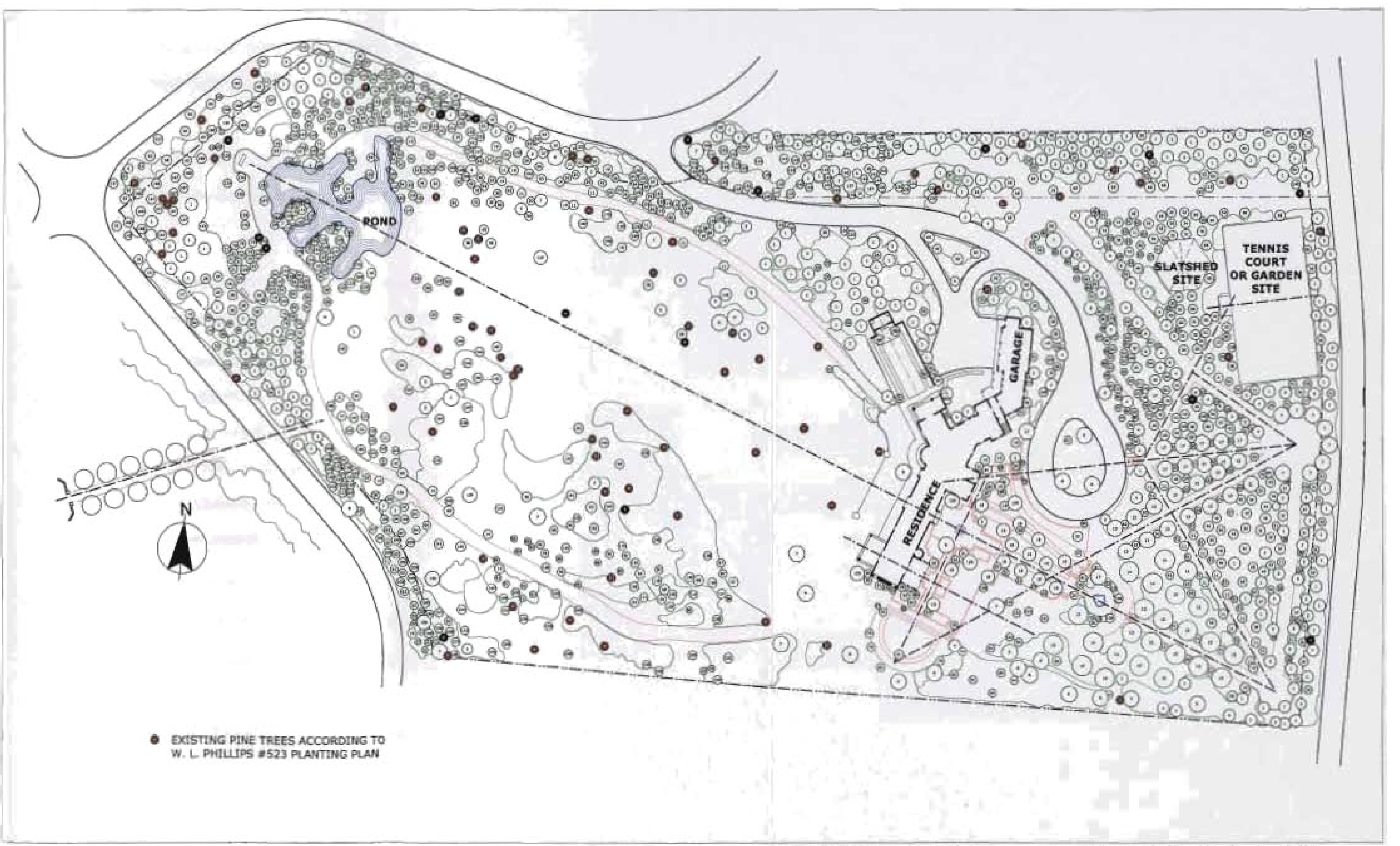

Figure 2.2 - Existing longleaf pines according to William L. Phillips Planting Plun \# 523 Source: Drawing by the author 
The effect of fire in longleaf pine soils creates different types in texture, drainage, and fertility. The Lake Wales Ridge, located on a sandhill, (Myers and Ewel 1990) is shown in Figure 2.3.

Soils found within Pinewood Estate have been modified, over time, to accommodate the more horticultural plant species used within the garden.

\subsubsection{Fauna}

The longleaf pine openstory plant community attracts many species of birds, although no particular type of bird is restricted to this ecosystem (Engstromet 1984).

Most commonly, bird species observed in the old-growth stands are the redcockaded woodpecker, the brown-headed nuthatch, and the yellow-breasted chat. Other species found in open pine-land habitats, but to a lesser extent, are the red-headed, and red-cockaded woodpecker, common ground dove, loggerhead shrike, eastern king bird and Bachman's sparrow (Myers and Ewel 1990). Since so much of the longleaf pine ecosystem is gone, most associated bird species have lost their habitat.

Other animal species that frequent this ecosystem are the Florida mouse, Sherman's fox squirrel, pocket gopher, and the gopher tortoise (Myers and Ewel 1990).

The Pinewood House Manager, Lisa Shaw, stated that some wildlife still frequent the estate, such as gray foxes, gopher tortoise, wood stork, birds, and butterflies. A species of snake, the indigo, inhabit the rock walls of the grotto and the west lawn pond. 


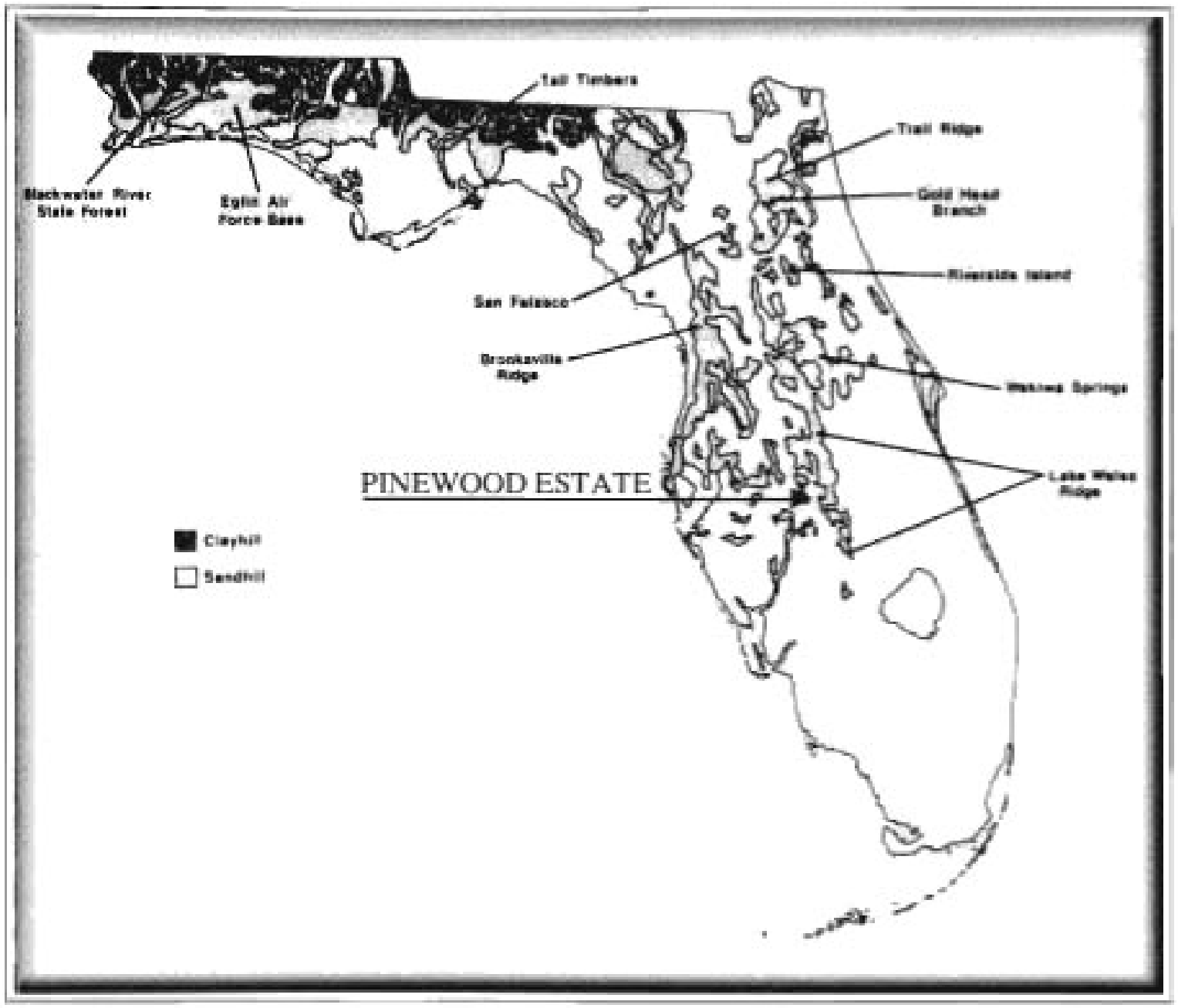

Figure 2.3 - Distribution of high pine clayhill and sandhill in Florida Source: Ecosystems of Florida. Meyer and Ewel. 1990 


\subsection{Overview of the Mountain Lake Development: Geographical Context, Social and Culture History}

Since the beginning of history, man has altered the land to ensure his survival. The $19^{\text {th }}$-century German geographer Alexander von Humboldt wrote:

"The earth and its inhabitants stand in the closest reciprocal relations, and one cannot be truly presented... without the other. Hence, history and geography must always remain inseparable. Land affects the inhabitants and the inhabitants the land." (Norton 1989)

In Florida, human settlements have existed for over 10,000 years. Before human occupation, it is understood that the area from southeastern Virginia to east Texas, as shown in Figure 2.3, was predominantly a longleaf pine/sand hill plant community (Myers and Ewel 1990).

The landscape started to change when Florida's aborigines began agricultural activities about 800 years ago. The European colonization, which started in 1565, caused gradual deforestation with the clearing of woodlands for agriculture, commerce (lumber and fuel), and for phosphate processing (Myers and Ewel 1990).

The early nineteen hundreds saw Florida become the new winter capital of the United States. Located in the subtropical region, it was very attractive for northern dwellers to come south and enjoy the warm winters.

During this time, Florida benefited greatly from the well-advertised climate and the high-powered promotion of tourism. In general, the country was going through a period of great prosperity. In Florida the absence of income and inheritance taxes promoted real estate investments (Caldwell 1984). 
The construction of railroads and their connecting roadways played a major role in the early development of Florida cities, such as Lake Wales. Founded in 1911 by the Lake Wales Land Company, the city is located in central Florida, removed from the State's most populated coastal regions. Once connected to the railroad in 1915, Lake Wales, with its citrus and phosphate industries, started to expand. New developments and the influx of tourists added to the city's expansion.

The Lake Wales Land Company used the pine forests to extract turpentine, and to supply the lumber industry. The Company also took advantage of the sandy soil to establish a vibrant grapefruit and orange citrus industry (www.cityoflakewales.com).

In 1914, Frederick Ruth, a young attorney from Queen Anne's County, Maryland, visited the family's property in Iron Mountain, Polk County, Florida. The family's undeveloped property was adjacent to the Lake Wales Land Co. where planting of citrus groves was already underway. Ruth envisioned the transformation of his property into a "City Beautiful” residential development, similar to Baltimore's Roland Park, where he grew up, complete with spacious residential properties on winding roadways, surrounded by woodland parks and a golf course. To accomplish this vision he purchased, in 1918, Iron Mountain itself and the land surrounding Buck Lake, which totaled more than 2,800 acres.

Since Frederick Law Olmsted Jr. was involved in the design of Roland Park, Ruth selected him and his firm as landscape architects of record for the design of his dream development. Olmsted first visited the Colony in 1914, and by mid-may of 1915, he submitted the first preliminary development plan, which took advantage of the dramatic 
topography and vistas of the environment. A second preliminary development plan (Figure 2.4) was presented in December 1916, with the block, lot and grove descriptions as described in the plan (Spain 1991). In addition to these substantial elements, the cultivation of citrus groves became a strong selling point for the Mountain Lake Corporation. Ten-acre lots where sold to the stockholders, and the remaining 500 acres were set aside for the country club, golf course, tourist hotel and winter homes along the shoreline of Lake Buck.

Unfortunately, the real estate boom in Florida started to fade by 1925 . Unscrupulous investors and real estate fraud became rampant throughout the state. Two hurricanes devastated Miami, West Palm Beach, and lake Okeechobee in 1926 and 1928.

Finally, in 1929, came the Mediterranean fruit fly infested the region, destroying seventy percent of the state's citrus trees; and in October, the U.S. experience the stock market crash that precipitated the historic depression of the 1930s.

Despite these unfortunate events, the Mountain Lake Corporation remained economically viable throughout this period of economic hardships. Despite all the bad publicity about Florida, residential lot sales and construction continued throughout the decades of the twenties and thirties (Caldwell 1984). It was at this time that Charles A. Buck first purchased and developed the property.

\subsubsection{Ownership, occupancy and development}

Throughout the seventy-year history of the Pinewood property, there has been a sequence of six owners as shown in Figure 2.5. 


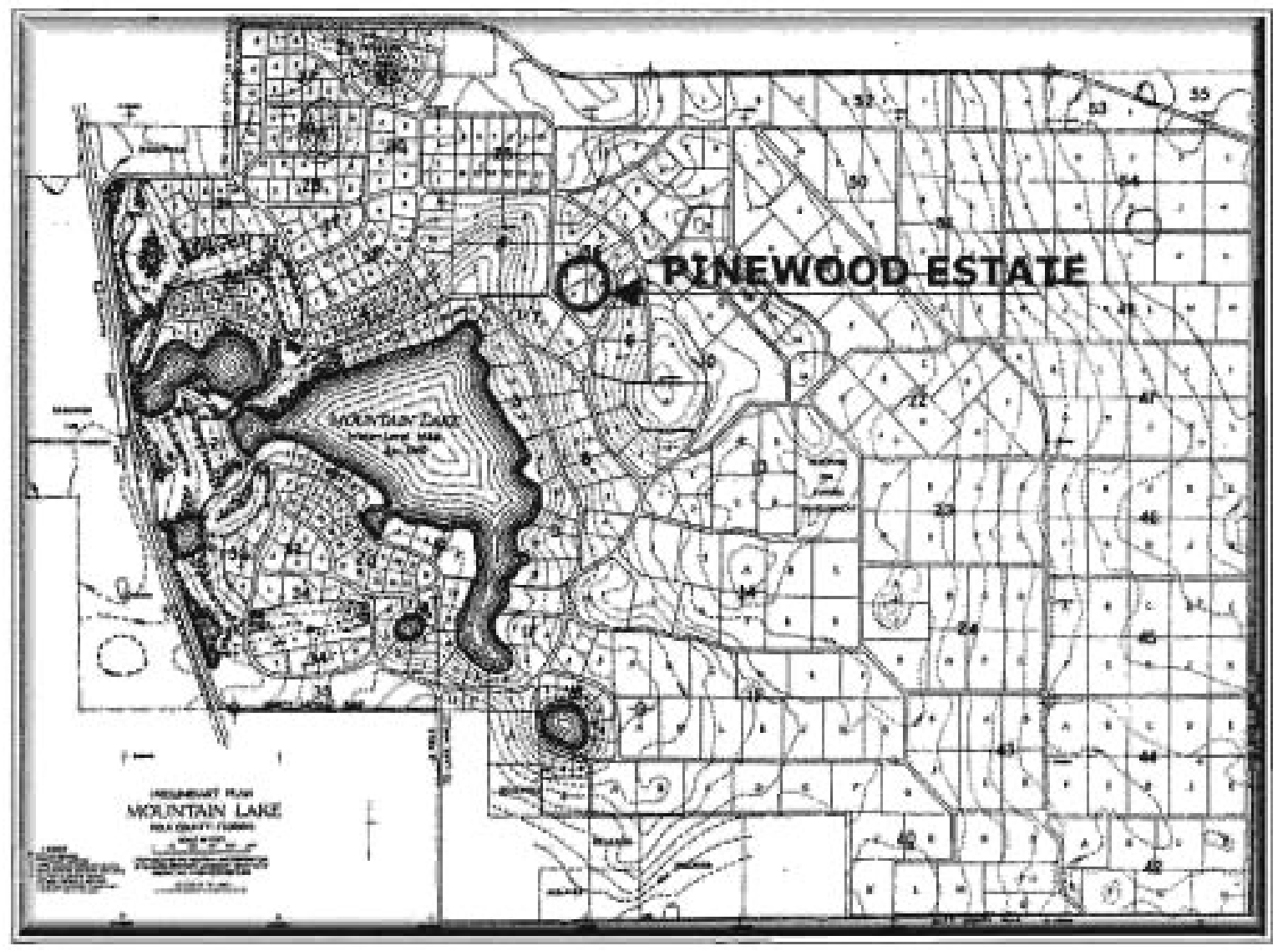

Figure 2.4 - Preliminary Plan Mountain Lake Colony, 1927

Prepared for Mountain Lake Corporation by Olmsted Brothers, Landscape Architects, Brookline, MA - December 1916

Source; Historical Association of South Florida, Miami Florida 


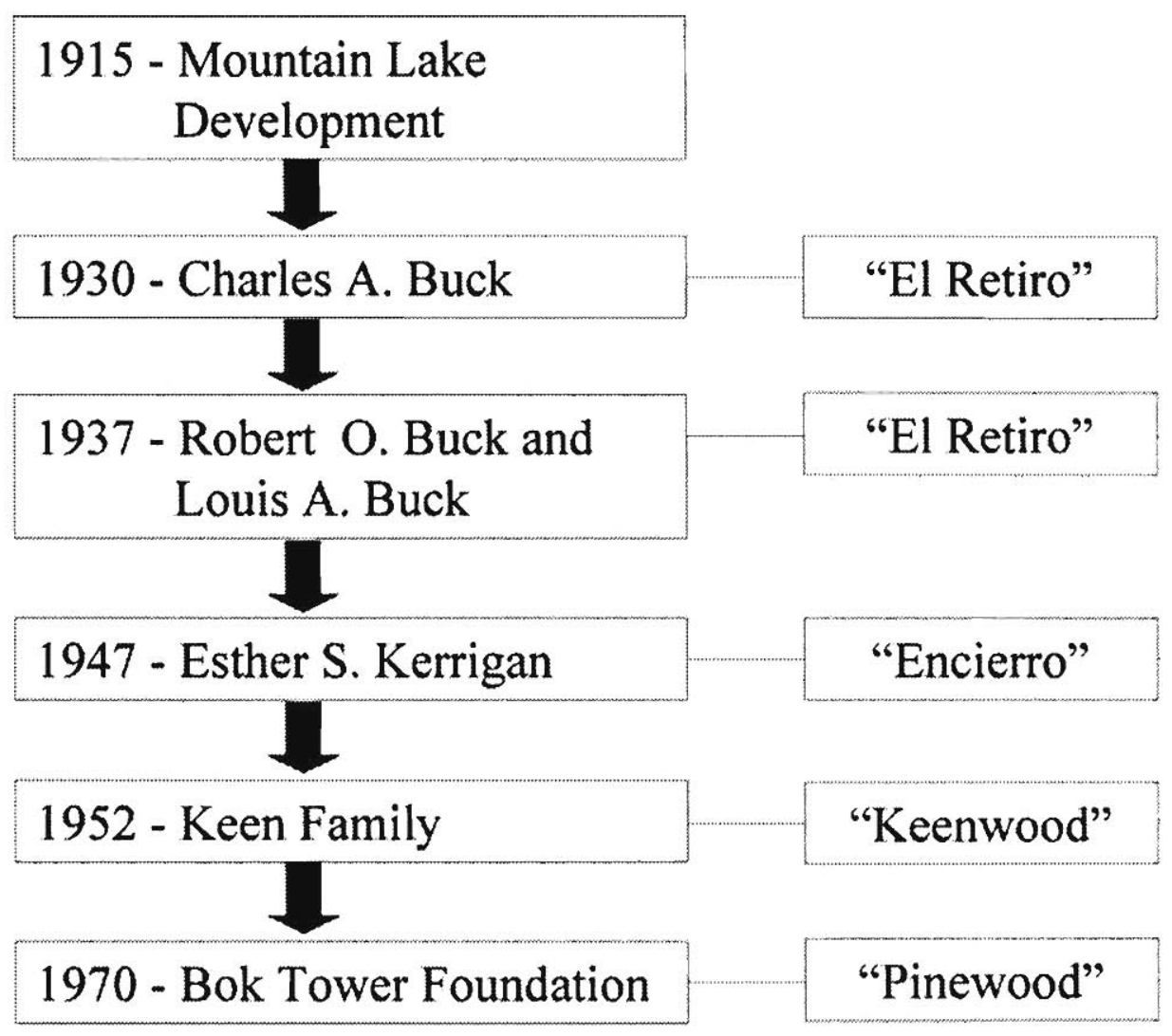

Figure 2.5 - Sequence of Ownership

Source: Compiled by author 
Charles A. Buck was born in 1867 in Bucksville, Bucks County, Pennsylvania. In 1887 after graduating from Lehigh University with a Bachelor of Science degree in Chemistry, he started to work for Bethlehem Iron Company. Bethlehem Iron sent Mr. Buck to Cuba for two years, to serve as a chemist for the Jugara Iron Company, where he was exposed to Spanish architecture and garden design. Upon his return to Bethlehem Iron in 1913, he became the third vice-president of the company. Later in his career, as president of Bethlehem Iron Mines in South America, he was again exposed to Spanish style design (Spain 1991).

Charles A. Buck's relationship with Mountain Lake began in 1925, when he visited the Colony after his wife Josephine passed away. During his visit, he stayed with his sister Gertrude G. Starkey. Later in February 1930, Mr. Buck purchased the property across the street form his sister's home (Spain 1991).

This transaction was registered in the Warranty Deed as Conveys Lot 5, Block 6, Revised plat of 'Mountain Lake' containing 7.59 acres, subject to the restriction that a residence must be built within three years or the first party may repurchase the property (Spain 1991).

At the time Charles A. Buck purchased the property, he was over 60 years old. Fittingly, he named the property "El Retiro" which translates from Spanish as "retreat or retirement." El Retiro was deeded to his sons Robert O. Buck, and Louis A. Buck, on April 15, 1937. Charles Buck died on July 13, 1945 in Bethlehem, Pennsylvania. 
In 1947, Esther Slater Kerrigan purchased the estate from the Buck sons and changed the name from "El Retiro" to "Encierro," another Spanish word that translates roughly as "seclusion or quiet life." She spent four winters at El Encierro through 1951.

The next ownership change occurred in 1952, the Keen family purchased the property The Keen family maintained ownership until 1967 when Mrs. Ruth Keen died. During this ownership period, the property was named "Keenwood."

The current owners, the Bok Tower Foundation (formerly The American Foundation) purchased the property in 1970 from the Keen Family (Spain 1991). The main reason for acquiring the estate was clearly expressed in a letter from Nellie Le Bok to the Board Members, where she expresses her concerns for the future, if the property is purchased for other uses such as a nightclub or shooting ring, which would be contrary to the mission of the Bok Towers Sanctuary. Mrs. Bok was also very fond of the property's design, and considered it important to preserve it for future generations (Spain 1991). The Foundation changed the name to "Pinewood" to reflect the longleaf pine habitat original to the site, prior to any intervention by man. 


\section{CHAPTER 3}

\subsection{Olmsted Brothers Design Approach}

The Olmsted Brothers was the leading landscape architecture firm during the period Fred Ruth developed the Mountain Lake Colony. Mr. Ruth wanted to apply the distinctive planning principles used by Frederick L. Olmsted Sr. in the design of Roland Park into his Florida development. His planning was comprehensive. Olmsted Sr. used the unique site characteristics of the Roland Park area in his comprehensive planning and design, such as streets, property parcels, and open spaces that reflected topography, vistas, and significant natural features. This was in marked contrast to the rigid orthogonal grid imposed on the land in cities throughout the country.

The planning principles used in Roland Park strongly influenced the practice of community and town planning throughout the $20^{\text {th }}$ century.

When Frederick L. Olmsted Jr. designed Plat 2 in 1901, he followed the natural contours of the land; preserving and heightening the picturesque succession of hill and valley, open space and forest (www.livebaltimore.com/history/roland_park.htm).

Olmsted Jr. came to Lake Wales in December 1914, where he visited the site. Mr. Olmsted sketched out natural pathways established by the rise and fall of the land and which were proved by animals and the occasional hunter and fisherman (Caldwell 1984). As in Roland Park, the Mountain Lake design was based on embracing and enhancing the natural features of the site. 


\subsection{William L. Phillips Design Approach}

William Lyman Phillips was born in Somerville, Massachusetts in 1885 . He attended Harvard University, where he received his Master degree with honors, in Landscape Architecture in 1910. As one of the best students of Frederick Law Olmsted Jr., he started to work with the Olmsted firm in Brookline, Massachusetts after graduation.

In 1913, the Olmsted firm put Phillips in charge of the site design and construction of the town of Balboa, located at the Panama Canal (Jackson 1997).

After the Balboa project, Phillips spent a year in France. He then returned to the Olmsted Brothers firm and, in 1923, he became the firm's local landscape architect representative at Mountain Lake. He remained involved in the Colony until 1932, supervising construction and designing many of the community's residential gardens (Frederick L. Olmsted National Historic Site Archives). As more residences were built, Phillips received many request from clients to design gardens for them independent from Olmsted Brothers firm (Jackson 1997). One of those requests was from Charles A. Buck.

\subsubsection{Design criteria for Pinewood Estate}

Charles A. Buck hired William Lyman Phillips based on his experience in residential landscape designs. Since Buck and Phillips had each lived in Latin countries, they shared a knowledge and love for the tropics, Spanish influence designs, and a passion for horticulture. As a component of the landscape design, new plant species were continuously experimented with. The Latin American influence is clearly seen in the estate's architecture and gardens (Jackson 1997). 
Phillips was involved from the beginning in the site design process, which gave him the opportunity to make the gardens an extension of the house. The house was sited by Phillips to obtain the most favorable views, breezes, and accessibility. Charles R. Wait designed the house in a classical Mediterranean style, which was very popular in Florida during this period.

As in an Italian Renaissance villa, the house is located on the higher point of the site, captivating the long views over the land (Jellicoe 1995). For the garden's design, Phillips primarily makes use of the Mediterranean Revival style. As the name indicates, the style is a combination of two different architectural expressions along the Mediterranean coast, Moorish-influenced Spanish, and Italian Renaissance. He achieved in this garden an important synthesis of his own eclectic style, incorporating diverse stylistic elements such as the Chinese moongate, and the English picturesque garden.

The formal garden of the east terrace is a Moorish style courtyard with the frog fountain arranged on the intersection of two important axes. The main axis runs east-west through the whole property as shown in Figure 3.1. Formal features such as a citrus grove defined by straight avenues ending in circles, and the English picturesque concept is used in the west lawn (Jackson 1990).

In a letter sent on June 5, 1929 to Mr. Charles A. Buck (Appendix A), Phillips proposed his design criteria. The criteria were based on a central long axis that runs from the southeast corner of the property with a roundel (a circular planting) of cypress pines (Callitris verrucosa) through the house and ends with a free form pond on the west edge of the site. 


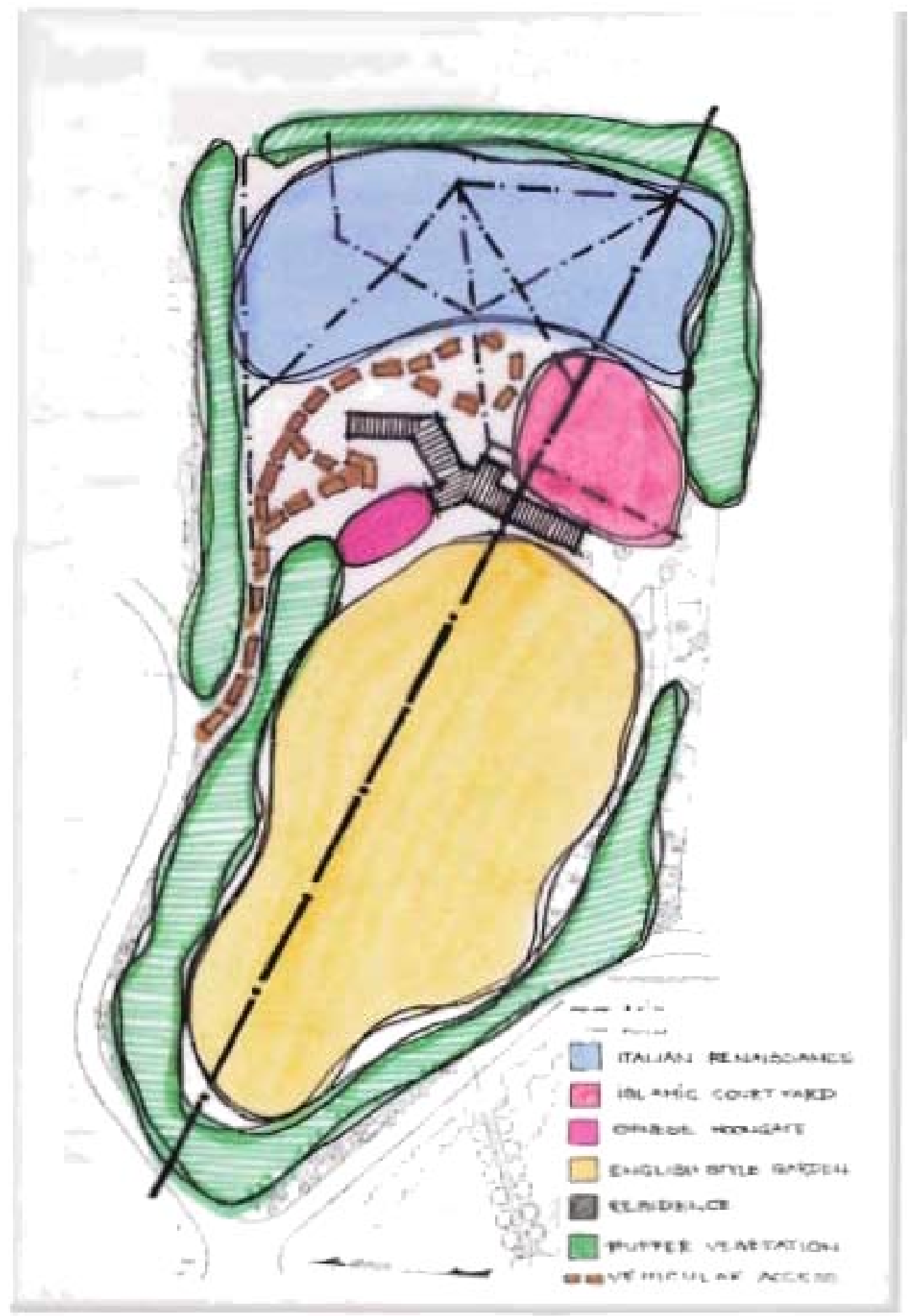

Fugure 3.1 - William L. Phillips Conceptual Design Diagram Source: Compiled by the author 
He makes a clear distinction in the views along the axis with:

- Long views to the free form pond or Bok Tower

- Short views to the formal cypress pines roundel or frog fountain

Having distinct vistas and spaces, makes the garden look much bigger then its 7.59 acres.

In his memoirs Phillips described his design criteria as a balance between "void and masses," "light and shadow." In some instances, he describes the open spaces as comparable to rooms and corridors in a picture gallery, in which the plants are "pictures" adorning the walls (Jackson 1997). This design approach was apparent in the original designs for Pinewood, and can be glimpsed even today.

The existing pine trees played an important role in locating the house. The contours were carefully studied so the top of the pine trees would not interfere with the views from the house (Figure 2.2). To achieve this, the westerly side of the house set to an elevation of about 250 feet, well below the height of the pine trees (Spain 1991).

Phillips suggested two ways to approach the house: either from the northern point of the lot, which would not interfere with the existing vegetation, or from the lowest point of the relocated Colony road, as close as possible to the edge of the property on the northerly boundary (Spain 1991). The curved entrance drive was laid out moving up towards the house-while the vegetation surrounding it was densely planted to prevent a view of the house. In his plan, as shown in Figure 3.2, Phillips designed the formal areas on the entrance side of the house, as a way to welcome visitors, while keeping the informal areas, on the west side of the house, for casual gatherings 


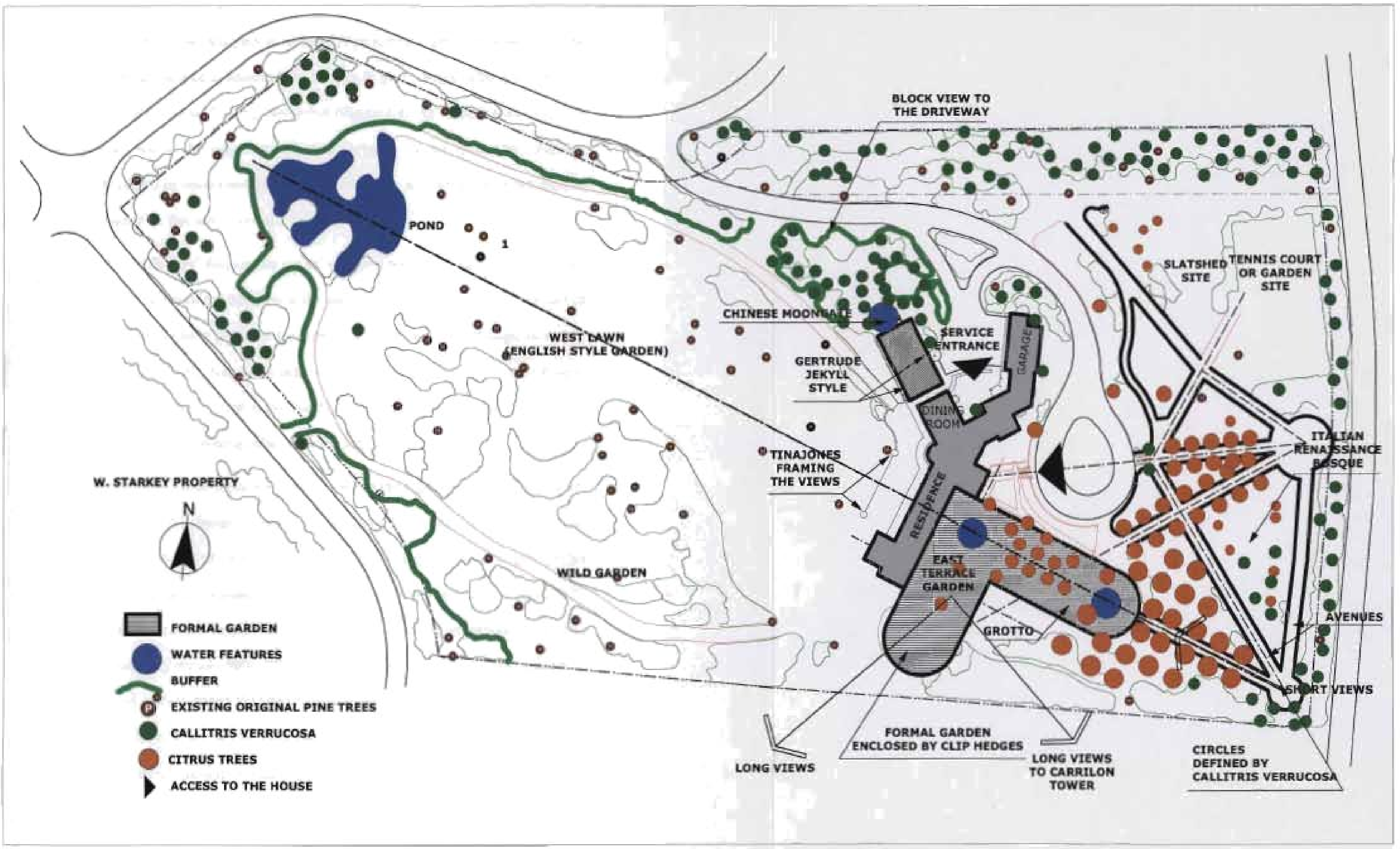

Figure 3.2 - Historic overview of William L. Phillips design ideas Source: Drawing by the author 
The west lawn was designed as an English picturesque garden (Figure 3.3). The boundaries were given special attention, in an effort to gain privacy, with mass planting of palms and cypress pines (Callitris verrucosa) (Figure 3.4). An exception was made on the east side, where the adjoining property belongs to the Sanctuary. Phillips recommended that it be maintained in a park-like condition, so it would seem that the two properties merged on that side (Favretti 1990).

In most of Phillips' designs, the use of water is a prominent feature. He proposed a free form pond, to create a focal point at the end of the main axis, on the lower part of the site. He used the water to play with the reflection of light and surroundings, as seen in Figure 3.5 (Jackson 1990). Natural sounds were also taken into account in his designs (Figure 3.6). Dripping water, such as the frog fountain and the grotto on the south side of the main axis, produced a calming effect (Jackson 1997).

The formal entrance to the house is located on the higher side facing southeast. Perhaps because of the change in grade, the entrance is off the main axis that runs through the house. As part of his eclectic scheme, Phillips included the moongate garden on the northwest corner, a popular feature in the first half of last century (Figure 3.7). This is an extension of the dining room porch, which was used as an outdoor dining area in special occasions (Favrreti 1990). This area has a small patch of lawn, surrounded by a blue, white, and yellow annual flowerbed, influenced by the Gertrude Jekyll's garden style (Favrreti 1990). Walls on two sides enclose this garden. The one facing the dining room has an octagonal opening, as seen in Figure 3.7, which exposes the fountain and its water jet. 

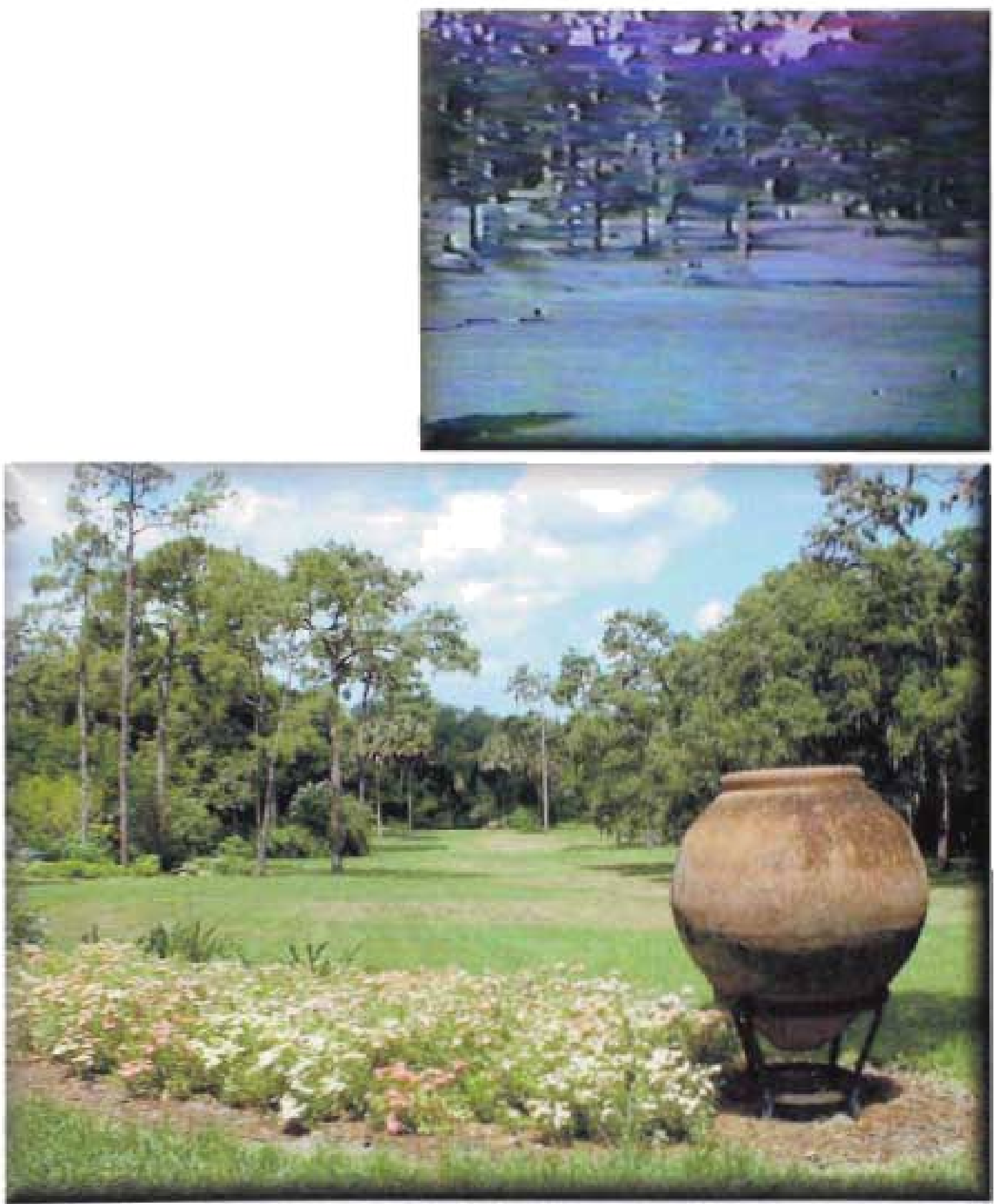

Figure 3.3 - Comparison of past and present views of the west lawn

The above figure is a view of the west lawn circa 1993, taken from the Buck family videos provided by Bok Tower Gatdens. The figure below is the view of the west lawn today taken by the author 


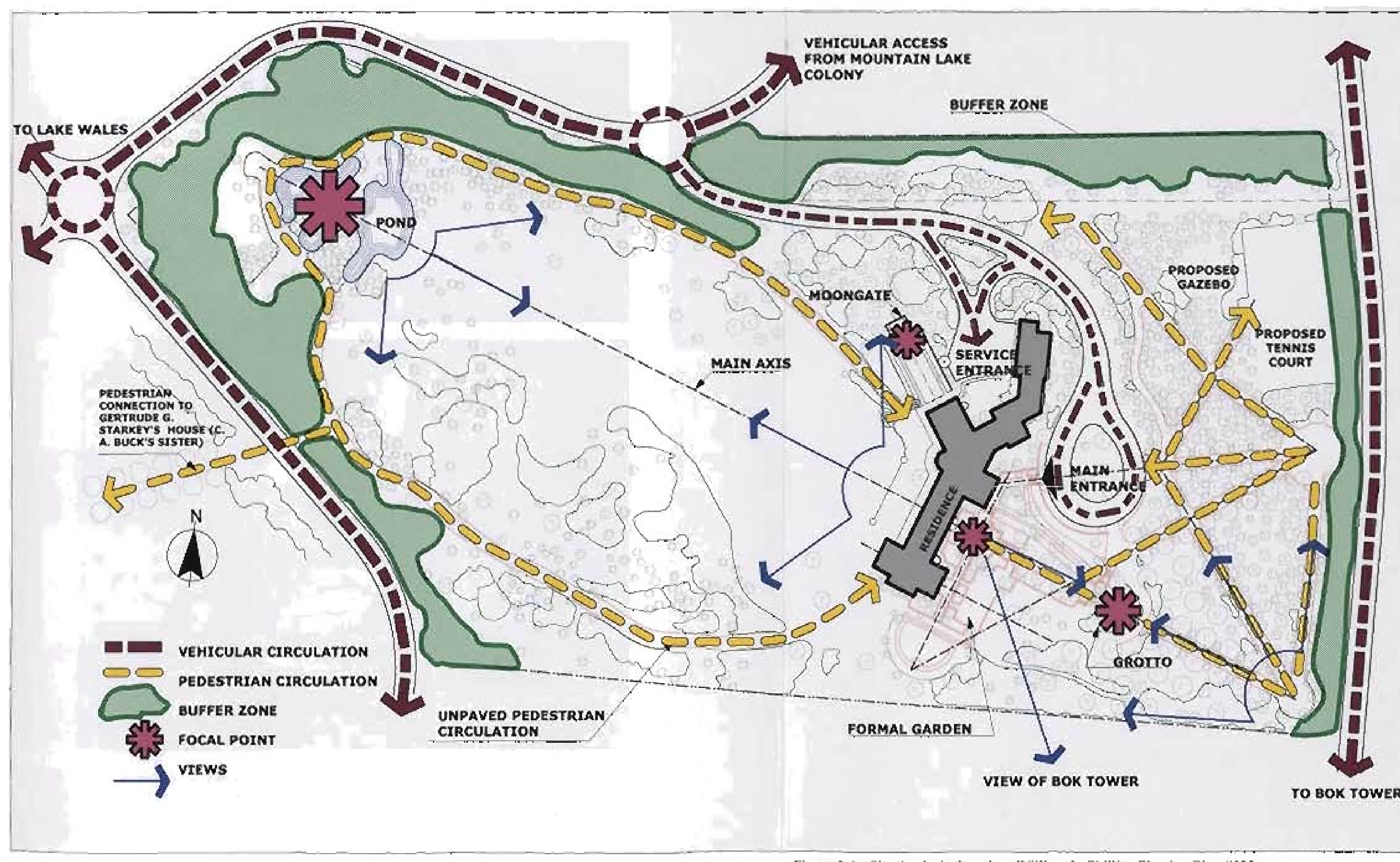

Figure 3,4 - Site Analysis based on William L. Phillips Planting Plan $\$$ \$523 Source: Drawing by the author 

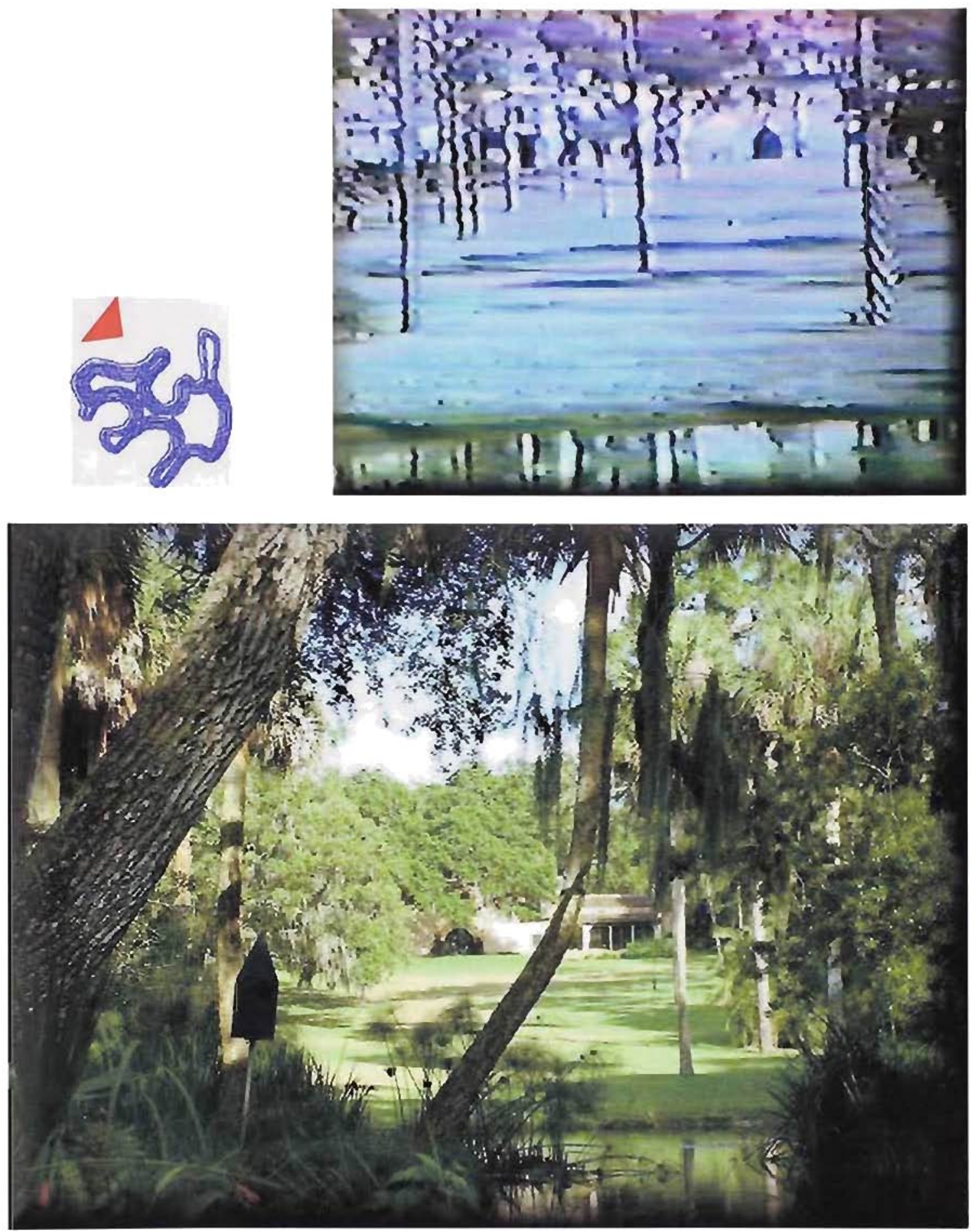

Figure 3.5 - Comparison of past and present views from the pond

The above figure is a view from the pond circa 1993, taken from the Buck family videos provided by Bok Tower Gardens. The figure below is the view from the pond today taken by the author 

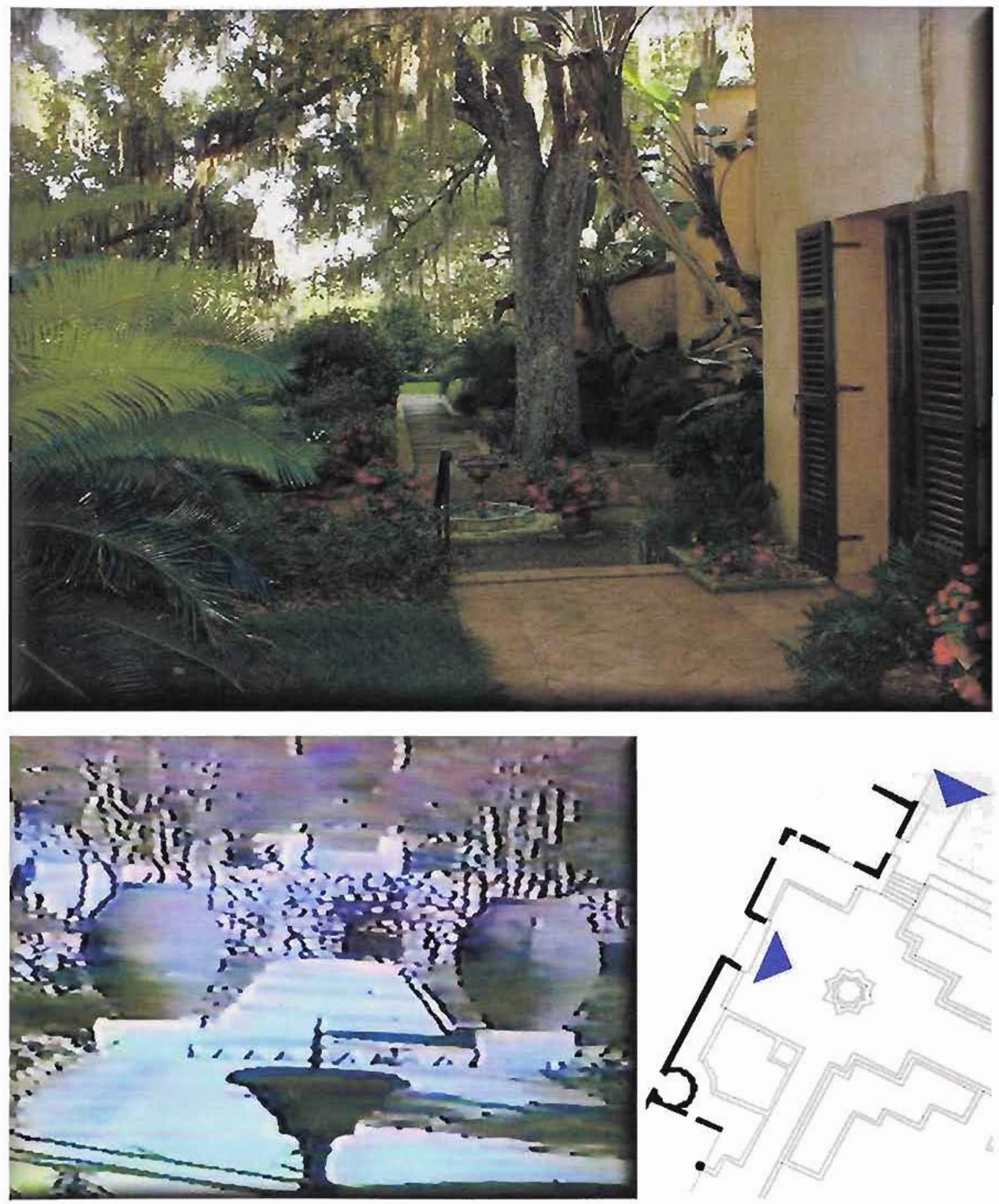

Figure 3.6 - Comparison of past and present views of the Frog fountain The above figure is the view of the Frog fountain today taken by the author. The figure below is a view of the Frog Fountain circa 1993, taken from the Buck family videos provided by Bok Tower Gardens. 

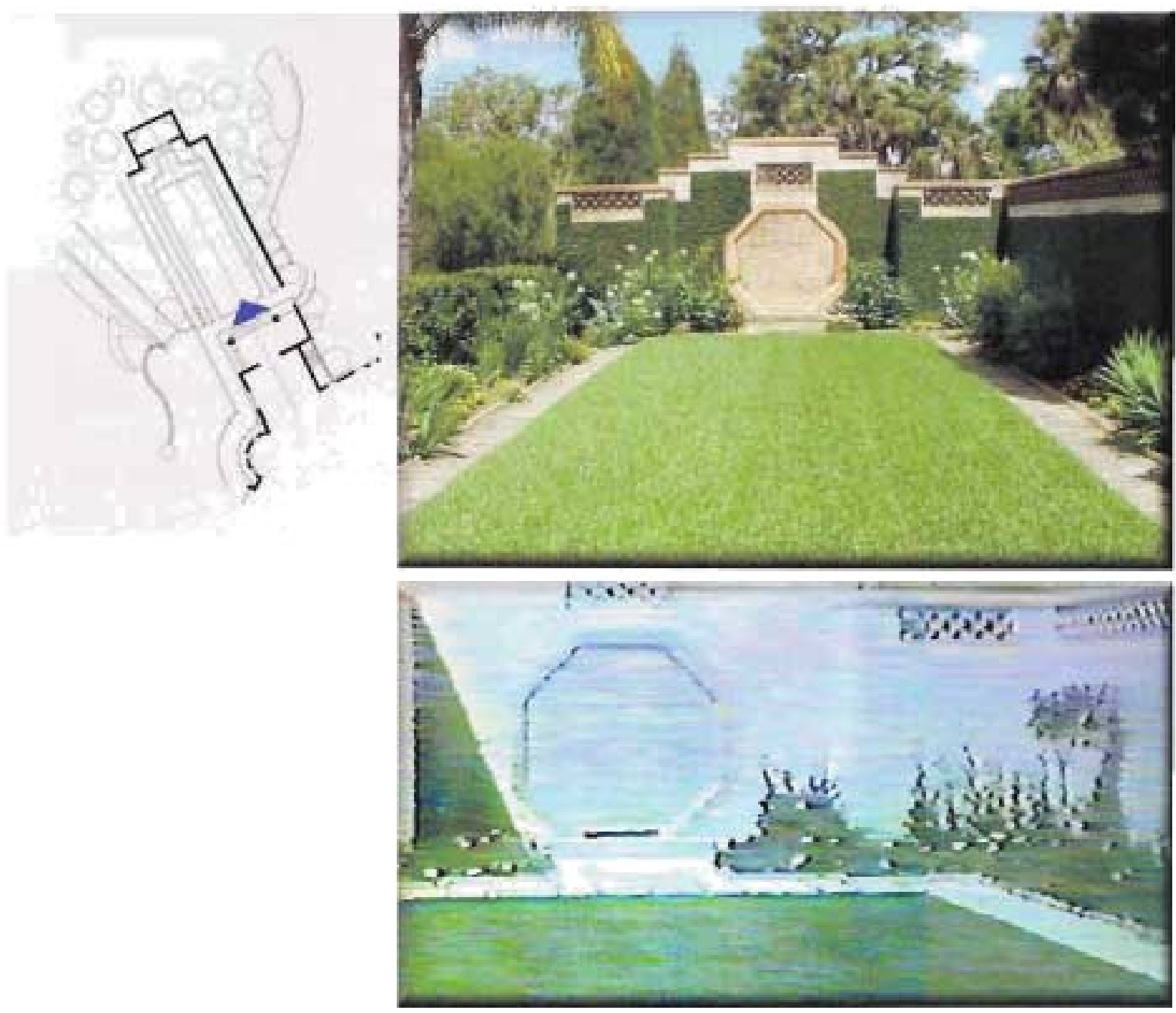

Figure 3.7 - Comparison of past and present views of the Moongate garden The above figure is the view of the Moongate garden and fountain today taken by the author. The figure below is a view of the Moongate garden and fountain circa 1993, taken from the Buck family videos provided by Bok Tower Gardens. 
Phillips wrote, "The Chinese placed a decorated gate screen behind the opening to keep out evil spirits, who can only travel in a straight line"(Spain 1991).

To create a view on the southeast side, Phillips located the bosque using the basic geometric layout of the Italian Renaissance. The grove is laid out as straight-line avenues finishing in circles (Favretti 1990).

The last planting plan in file \#6023, according to the Olmsted Brothers archives, is Plan 523 (Figure 3.8), which has a detailed planting list on the side (Appendix B). It also shows a tennis court that was never built. Instead, this space was used as a vegetable garden, supplying all the vegetables and salads fixing for the household (Spain 1991). On October 1, 1929, C.A. Buck responded in a letter to W.L. Phillips indicating his approval of that scheme for his site at Mountain Lake (Spain 1991).

In September of 1930, the Mountain Lake Corporation had completed the clay drive, a large portion of the rough grading, concreting the pond, most of the irrigation, and the majority of the lower lot plantings (letter from Phillips to C.A. Buck, September 8, 1930 in Appendix A).

\subsection{Restoration Process}

The gardens had been neglected since Charles A Buck's death the mid forties. Because of the many years of neglect and hard freezes, much of the original planting material from Buck's time was no longer there when the American foundation acquired the property from the Keenwood family in 1970. Several restoration efforts have been undertaken and are summarized in Figure 3.9. 


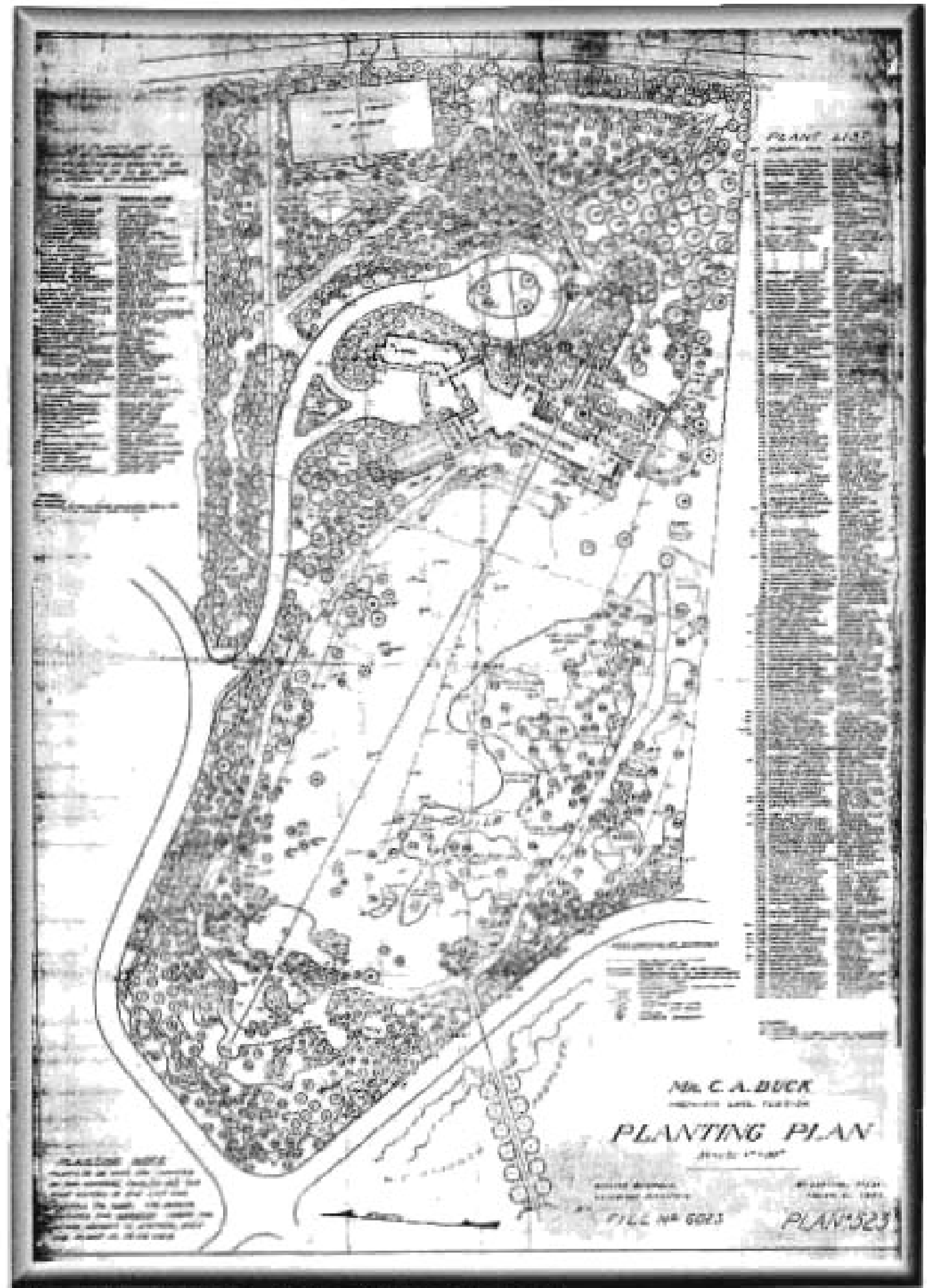

Figure 3.8 - William L. Phillips Planting Plan \# 523

Source: Bok Tower Gardens Archives 


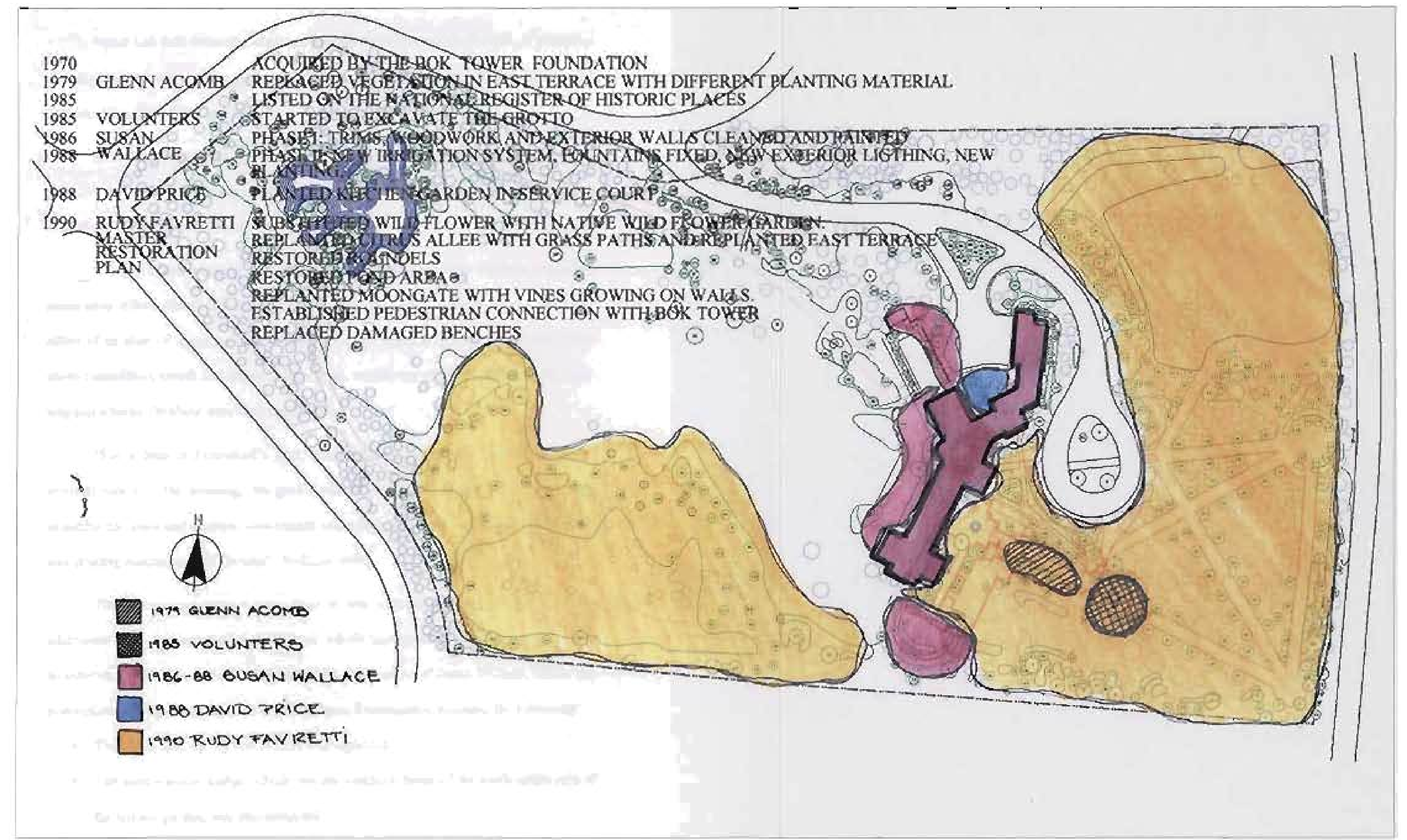

Figure 3,9- Restoration Process Source: Drawing by the author 
Nellie Lee Bok retained Landscape Architect Glenn Acomb, in 1979, to prepare a plan for the restoration of the garden. He re-planted the east terrace, using plant material different from that of Phillips' original design (Spain 1991).

Volunteers started the excavation of the grotto in 1985. This revealed the coquina rock along with the main water jet, and the four fine jets on the perimeter became visible once three-and-a-half feet of sand were removed.

In 1986, Susan Wallace, assistant horticulturist at Bok Tower Gardens, began her restoration effort. She disagreed with Glenn Acomb's plant material substitution. The effect of an allee of upright seedling citrus trees was changed into a mass of dark green blobs (camellias), awash in a sea of mondo grass, which was very different from Phillips' original scheme (Wallace interview June 1989).

"For a time in Pinewood's past, benign neglect allowed a seedling forest to overrun much of the planting, the grotto was filled in with sand and trash, and the beautiful tile steps and benches were hidden under dirt and leaves. Only minimal mowing and pruning maintained the gardens" (Wallace 1988).

The restoration process was done in two phases. Phase I, begun in 1986, addressed only the exterior of the house, which was painted and trimmed, and the woodwork was redone. Phase II, done under the supervision of Susan Wallace, started the restoration of the garden (Spain 1991). The Phase II restoration included the following:

- The citrus allee by the east terrace was replanted

- The semi-circular hedge, which was the southern focus of the north-south axis of the terrace garden, was reconstructed 
- The hedges around the flowered parterres in the east terrace were replaced with boxwood

- The vines (ficus pumila) covering the house and garden walls were removed because of termites eating the wood eaves

- Two large eucalyptus trees by the service entrance in the southeast corner of the house were removed (Spain, 1991)

- The wildflower garden was removed because it requires a lot of maintenance

Following the completion of Phase II, Rudy Favretti was hired in 1990 to create a Master Landscape Restoration Plan: Pinewood (Spain, 1991).

\subsubsection{Rudy Favretti Master Restoration Plan}

In his analysis, Rudy Favretti feels very strongly about maintaining the overall essence of Phillips' design, which he captured in his plan shown in Figure 3.10. In Favretti's master plan, as seen in Figure 3.11, he categorizes the following three features:

1. The central visual axis and the belt of trees as being the primary features to preserve. These are the elements found in the west lawn and show the influence of the English garden style used in the $18^{\text {th }}$ century.

The belt planting is much deteriorated along the property line. The cypress pines (Callitris verrucosa) in this area should be replaced according to the original plan. These are important elements, because they inspire the Mediterranean look.

Since the light condition in the pond area has changed, from a sunny to a shady area, the plant material needs to be modified according to these conditions. Favretti proposes the use of similar shrubs such as azalea cultivars. 


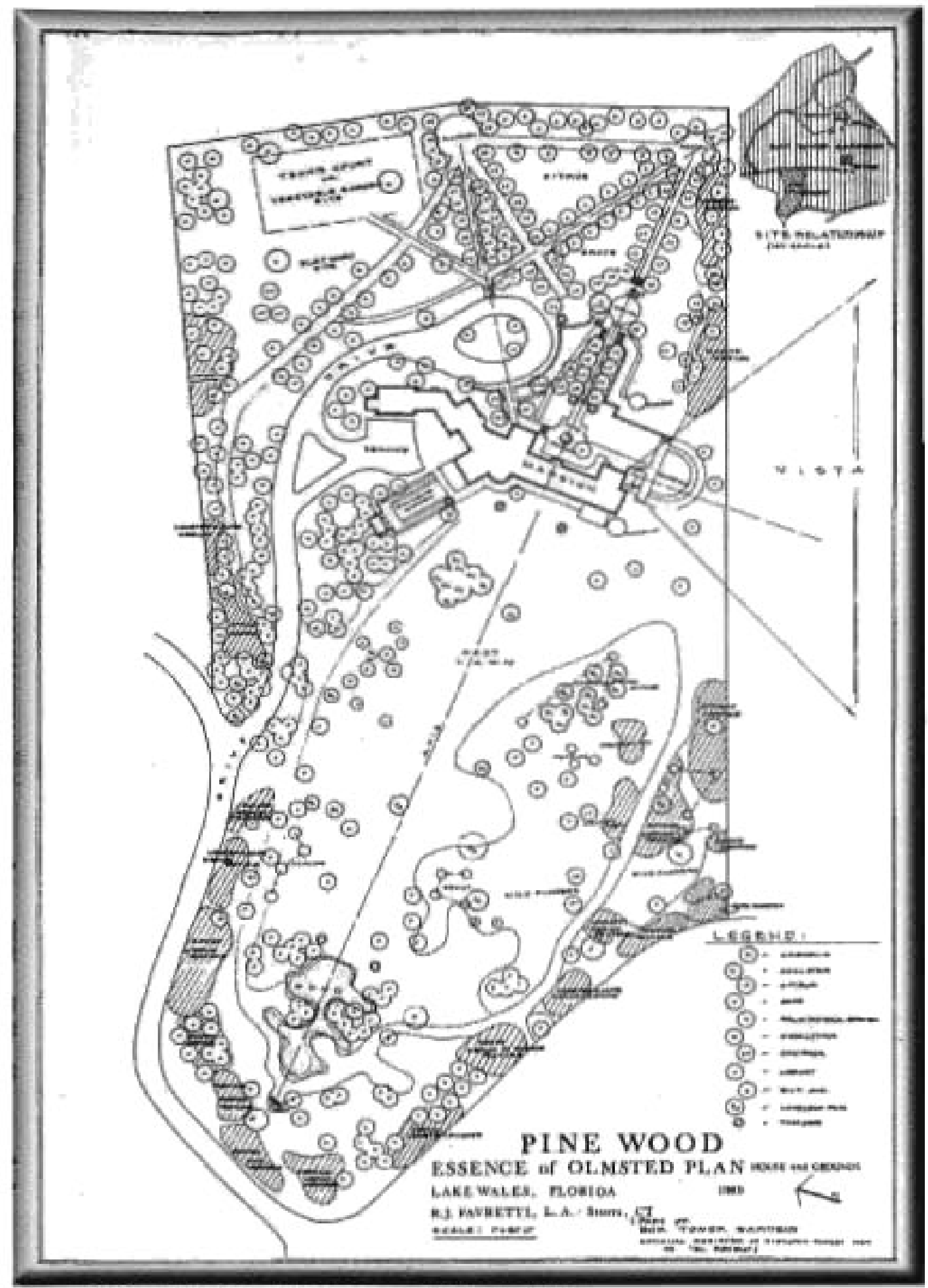

Figure 3.10 - Rudy Favretti's Essence of Olmsted Plan Source: Bok Tower Gardens Archives 


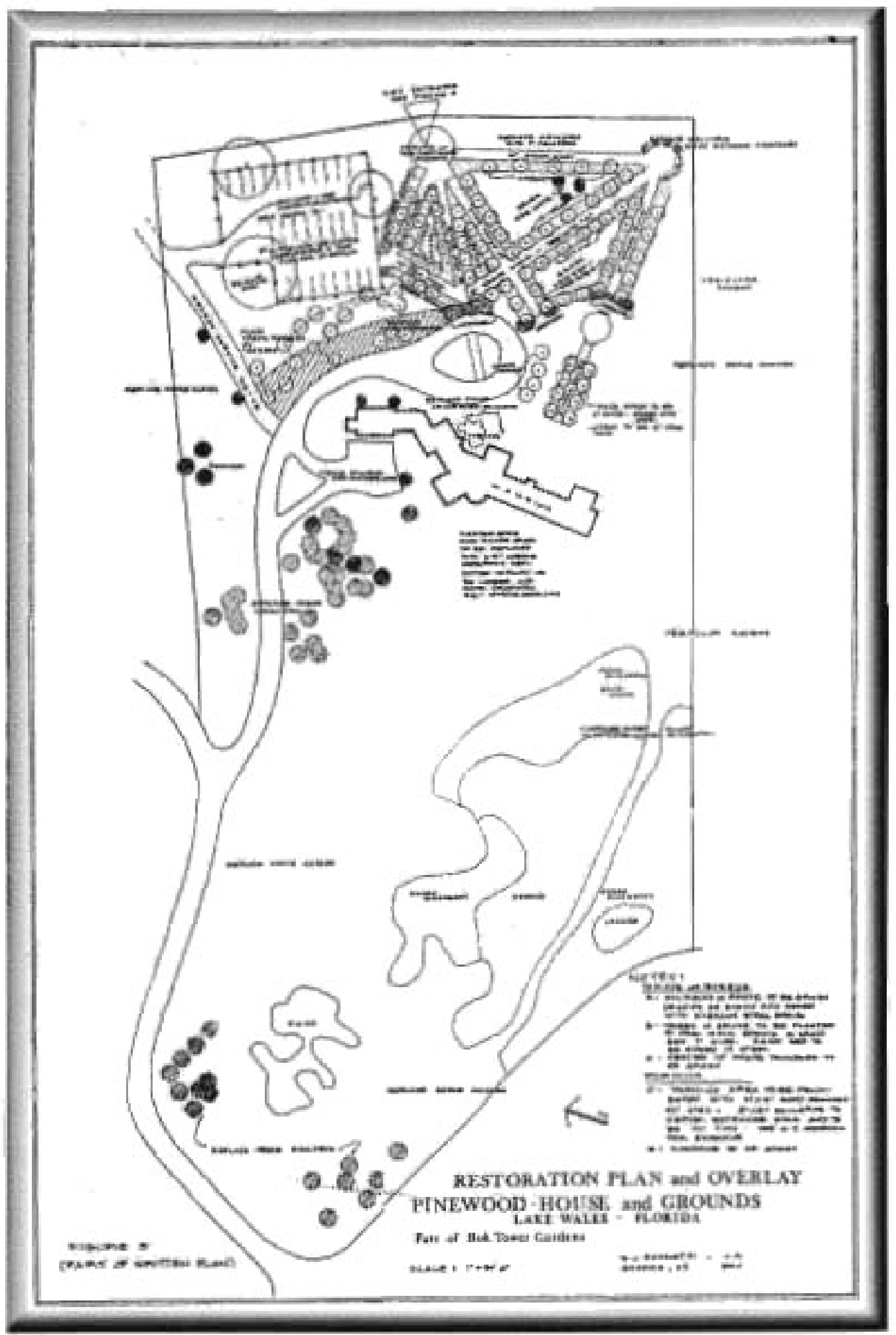

Figure 3.11 - Rudy Favretti's Restoration Plan Source: Bok Tower Gardens Archives 
The wild flower garden should be substituted by Florida's native wildflowers.

2. The essence of the original design is still clearly visible today. The two formal gardens, the moongate, and the east terrace define outdoor spaces by using welldefined clip hedges.

3. The last items addressed in his restoration plan analysis, are the vegetable garden and the wildflower area.

Others details to be preserved, according to Favretti's plan, and which are important in defining the character of the site are:

- The large oak trees used to create spatial canopy and to accentuate vistas surrounding the mansion

- The citrus grove within the bosque in the southeast corner of the site

- Mass planting of plants such as: magnolias, jacarandas, azaleas, and several others add interest in the landscape

- The moongate fountain, the frog fountain, the pond, and the grotto, as well as the "tinajones," all of which are critical as accents, termini, or mood "setters" (Favretti Master landscape restoration plan 1990)

His recommendations are based on a change of use of the garden, from a private residence, to a garden open for public access. That implies a maintenance plan and budget substantially different than at the time when Charles A. Buck owned the estate.

Elements in the restoration plan that were implemented were the following:

- The pedestrian conection between Bok Towers and Pinewood Estate, as shown in Figure 3.12, was established 


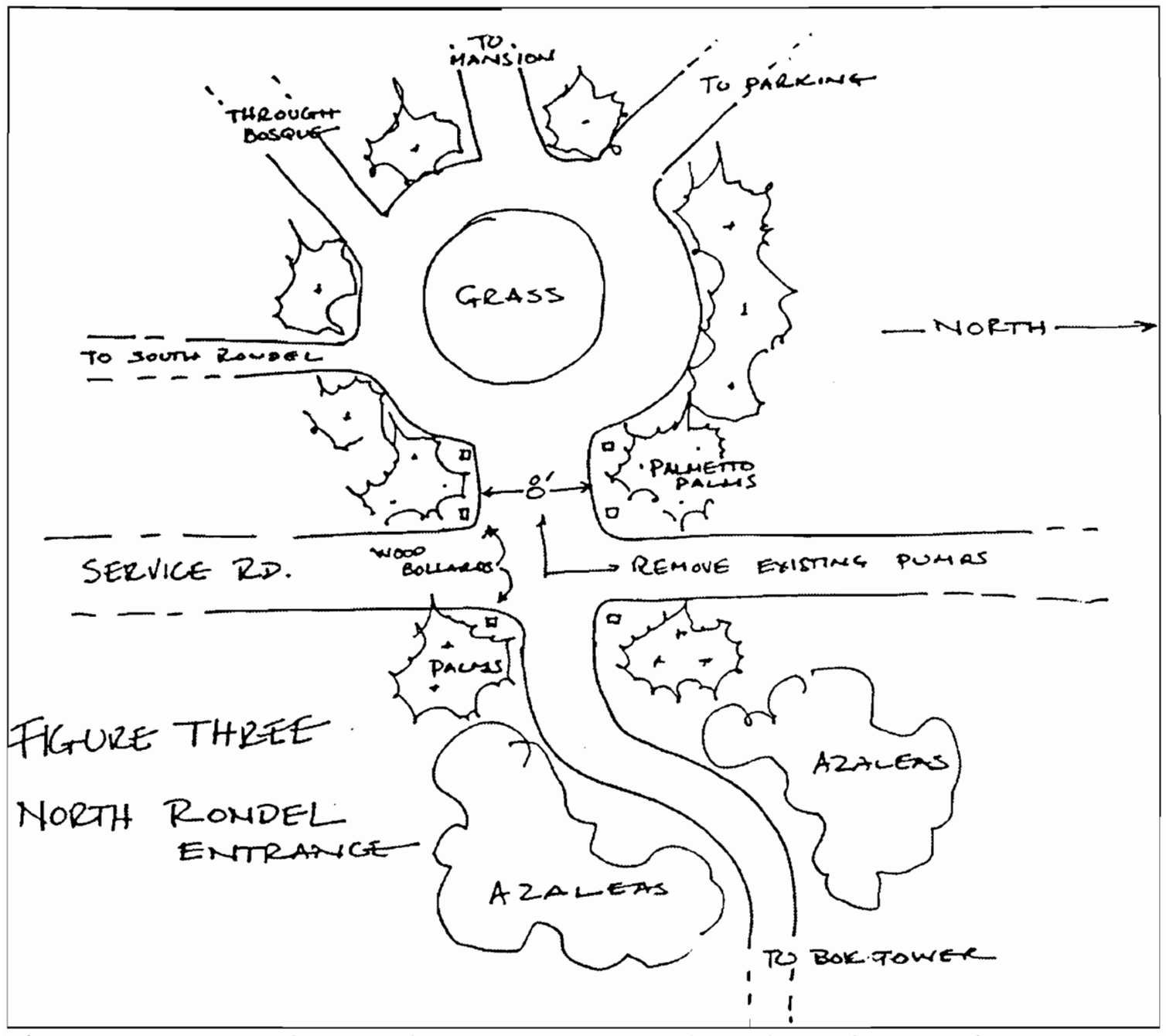

Figure 3.12 - Connection to Bok Tower Gardens Designed by Rudy Favretti Source: Rudy Favretti Restoration Master Plan 
- The citrus grove was restored with grass in the center in order to reduce the number of citrus and other plants

- The roundels, as critical elements in the design because they conect the avenues and are the termini to the main axis, were restored

- The wild flower garden was substituted with Florida's native wildflowers

- The pond curbs, edges and floor were repaired

- The vines (ficus pumila) on the moongate walls were re-planted

- The fountains were repaired

- Damaged benches were replaced

\subsection{Case Study: McKee Botanical Garden}

McKee Botanical Garden is an excellent case study, since it has been recently rehabilitated under the Guidelines for Treatment of Cultural Landscapes from the Secretary of the Interior's Standards for Treatment of Historic Properties.

William Lyman Phillips designed this garden in a very similar period as Pinewood, and many of his criteria are visible in both sites, such as the use of an axis as the backbone for vistas and spatial organization. Both properties are listed in the National Historic Register, because of their historic integrity.

The original owner's intended use for these two properties was very different when they were acquired. However, as both properties' use has changed over time, today they share a similar purpose. Pinewood Estate is now part of Bok Tower Gardens, a place 
for reflection, and a place that grants visitors an opportunity to connect back to nature, as is the McKee Botanical Garden.

McKee Botanical Garden is located on U.S. Route 1, three miles south of Vero Beach, Florida. By 1919, this area had become a major citrus fruit-shipping center and was experiencing a real estate boom, like the rest of the State of Florida.

Arthur G. McKee and Waldo Sexton established the McKee-Sexton Land Company in 1922 with the purpose of buying 80 acres of a 2,000-year-old oak hammock in order to preserve it from future development by the growing citrus grove industry. McKee and Sexton had a special interest in horticulture, and used the site for personal retreat and enjoyment of the natural landscape.

As times changed, in 1931, the owners decided to create a profitable garden open to the public. They engaged William Lyman Phillips and his assistant Winton $\mathrm{H}$. Reinsmith, to design a botanical garden that would combine existing features into one harmonious setting. This project marked a new trend for Phillips in his work, because he was no longer working as the Olmsted Brothers representative in Mountain Lake Colony. Because of the depression, he had to start to move away from expensive residential work into public work (McKee Botanical Garden Master Plan).

By January 1, 1932, the garden was officially open under the name "McKee Jungle Gardens." Over the years, many features were added, such as animals and bird displays, as well as a nationally recognized orchid and water lily collection.

The garden's operation suffered through many financial difficulties, and finally closed in 1976. The property was subsequently sold, and the Vista Gardens 
condominiums, together with a golf course, were built on the site. Only 18 acres, the heart of the garden, were spared from development. The Indian River Land Trust acquired this remaining parcel in 1995 to prevent its conversion into a shopping center.

\subsubsection{Site and Period of Significance}

Under the Guidelines for the Treatment of Cultural Landscape, the site is a historic designed landscape since it meets the following criteria:

- Consciously designed by a landscape architect: William Lyman Phillips, who was influenced by Olmsted Brothers criteria and assisted by Winton H. Reinsmith

- Associated with significant persons: Arthur G. McKee, a wealthy and innovative industrialist and Waldo E. Sexton, a trained agriculturist and successful entrepreneur in the Vero Beach area

- Reflects a cultural/historical trend in landscape architecture: The McKee family's initial interest in the site, and later the McKee and Sexton's action to preserve it as a natural area, and protect it from the developing citrus industry, reflected the emerging theories and beliefs about preservation of natural areas, natural study and sciences (McKee Botanical Garden Master Plan 1997)

\subsubsection{Period of significance}

Phillips started the landscape design for the McKee Botanical Garden in 1931, and revised the plan in 1938. According to photographs and other documents, the period that best reflects the founder's vision of a "designed jungle" is around 1931-1946.

McKee bought out his partner's interest in the garden in 1946, and was active until 1955, a year before he died. His grandson, Arthur M. Latta, became director of the 
gardens in 1960 (McKee Botanical Garden Master Plan 1997).

\subsubsection{Recommended Treatment}

According to the Guidelines for Treatment of Cultural Landscapes, four treatments can be used. They are as follows:

- Preservation: defined as "the act or process of applying measures necessary to sustain the existing form, integrity, and materials of an historic property. It requires retention of a significant amount of historic fabric, including the landscape historic form, features, and details as they have evolved over time"

- Rehabilitation: defined as "the act or process of making possible a compatible use for a property through repair, alterations or additions while preserving those portions or features which convey its historical, cultural or architectural values"

- Restoration: this standard allows for the depiction of a landscape at a particular time in US history, by preserving materials from the period of significance and removing materials from other periods

- Reconstruction: this treatment establishes a framework for recreating a vanished or non-surviving landscape with new materials, primarily for interpretive purposes

In the preparation of the Master Plan, done by Wallace, Roberts \& Todd, rehabilitation was used since the significant historic features being in poor condition, they could be protected while repairs and replacements could be done for a compatible new use of the property (Figure 3.13). 


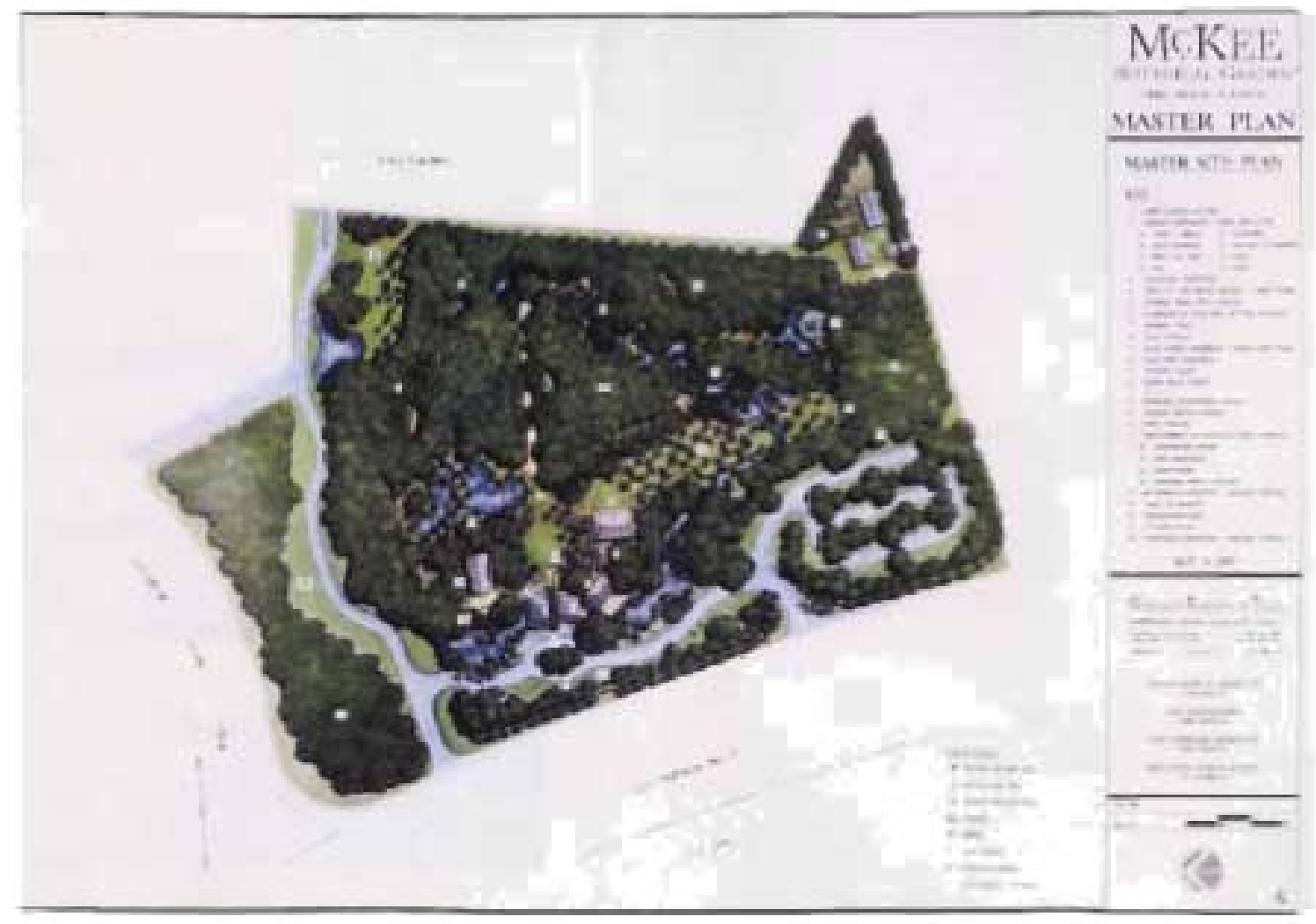

Figure 3.13 - MacKee Botanical Garden Master Plan

Source Wallace, Roberts and Todd 


\section{CHAPTER 4}

\subsection{Site Analysis}

\subsubsection{Location}

The Pinewood Estate is part of the Bok Tower Gardens, in Mountain Lake Colony, Polk County, and lies among the rolling hills of Iron Mountain, the highest ground in peninsular Florida (Figure 4.1).

Orlando is a city with many tourist attractions, only one hour away from the estate. U.S. Hwy 27 connects the site with Orlando and Miami as well. Tampa and Vero Beach are close by, as shown in Figure 4.2 (www.boktower.org).

\subsubsection{Access}

The access to Bok Tower Gardens is well signalized from U.S. Hwy. 27 (north/south) and State Hwy 60 (east/west). Interstate 4 crosses the state 25 miles north of Lake Wales, and both the Tampa and Orlando International Airports are approximately one hour's drive away (www.maptech.com).

The Site Analysis shown in Figure 4.3 indicates the access form Bok Towers to the entrance to Pinewood Estate. This is a small-unpaved red clay road with only one sign. The other vehicular entrance to the estate is through the winding roads of Mountain Lake Colony and has only a small sign by the entrance of the driveway.

On the east side of the property, by the red clay road, there is a pedestrian access to Bok Towers. This entrance is very discreet and connects with a curved path into Bok Towers Garden. It is not handicap accessible. 


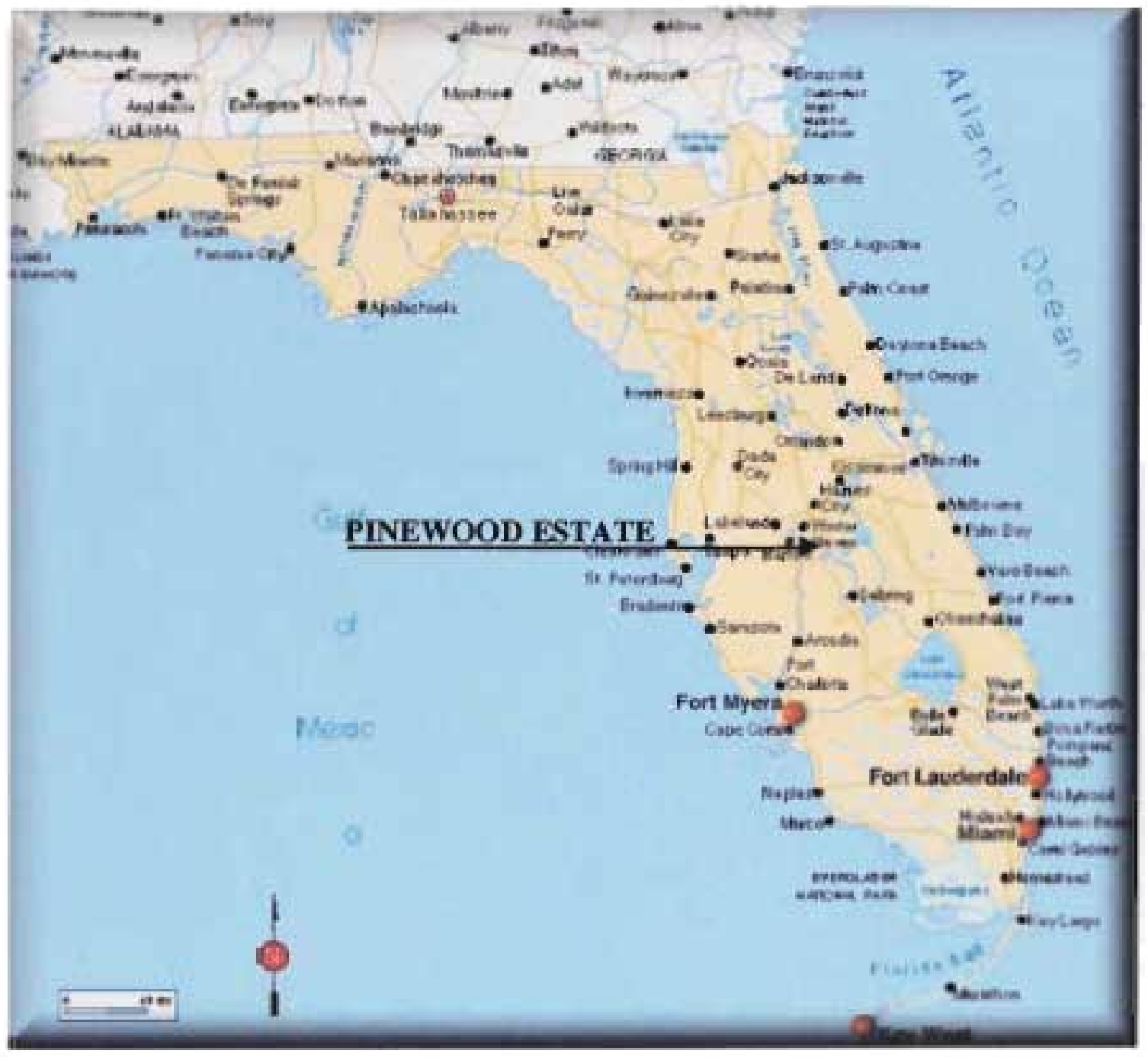

Figure 4.1 - Florida Location Map

Source: www.maptech.com 


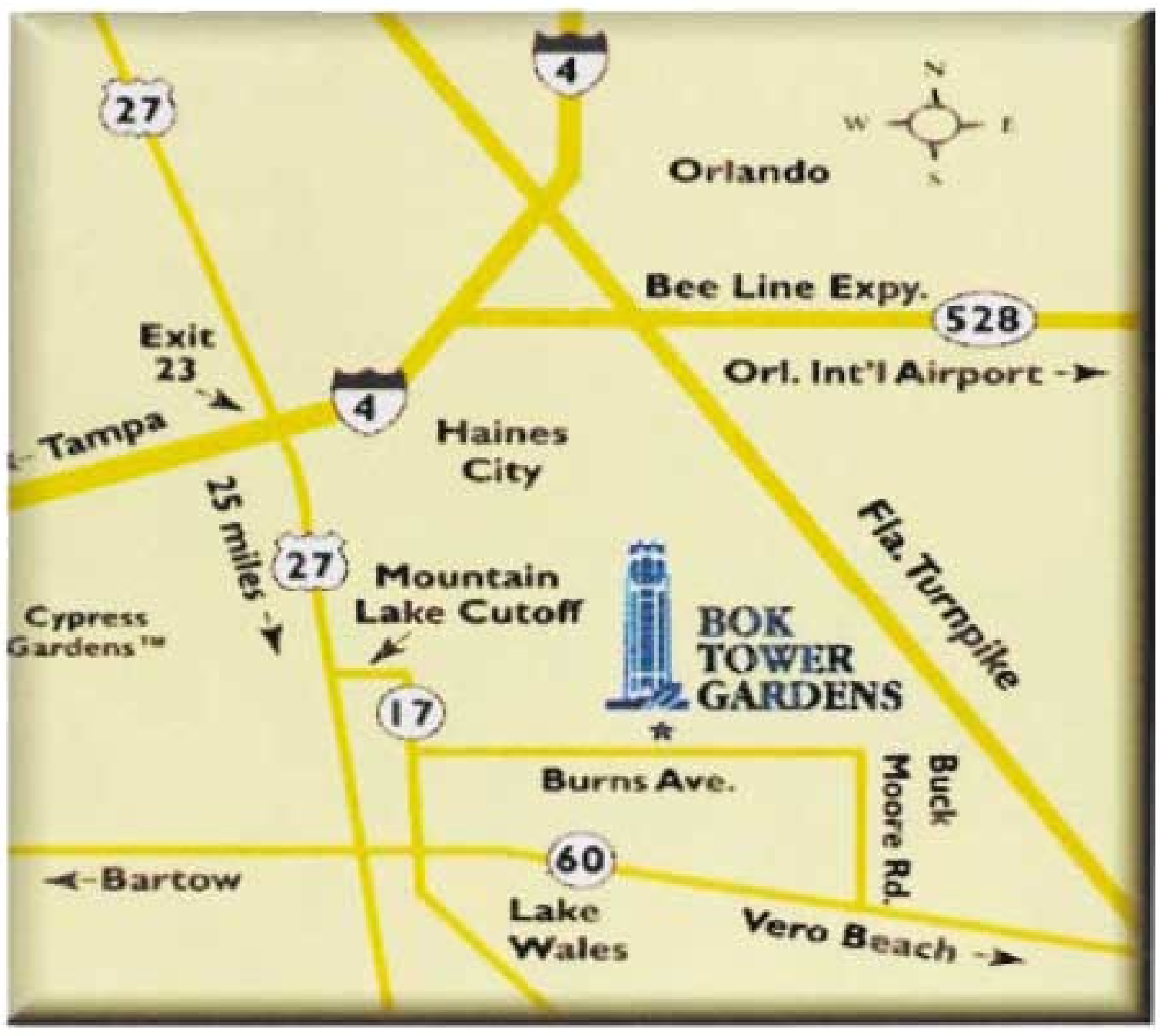

Figure 4.2 - Access Map to Bok Tower Gardens and Pinewood Estate Source: www boktower org 


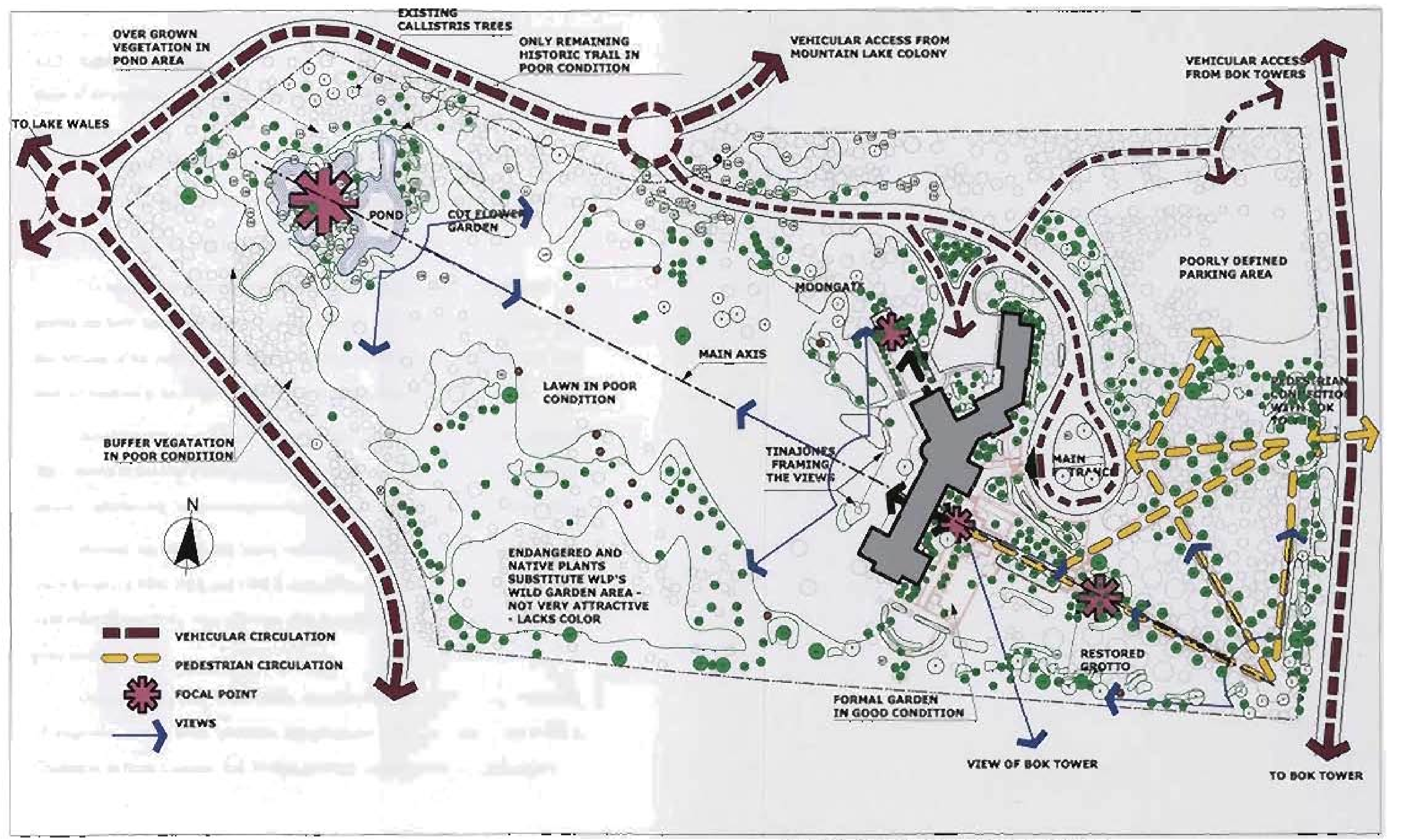

Figure 4,3- Site Analyxis based on current conditions Source: Drawing by the authot 


\subsubsection{Existing vegetation}

Some of the prominent design criteria found in Phillips' planting plan \#523, are still present today, such as:

- The Italian Renaissance citrus grove

- The Moorish style east terrace enclosed by formal clipped hedges

- The English style west lawn surrounded with buffer vegetation

As described by Rudy Favretti in his Master Restoration Plan, over time, the garden has been modified and only partially restored. Trees lined along the paths is all that remains of the citrus grove, with lawn covering the rest of the area (Figure 4.4). This does not conform to the original planting plan, nor reflect the designer's intention.

Susan Gammons, working as Horticulture intern at Pinewood during the spring of 2001, started to develop a plan with a detailed inventory of the current plantings in the garden. Unfortunately, her internship was cut short, and the plant inventory is incomplete.

Because the garden was barely maintained from 1945 to 1985 , as well as the many freezes in 1940, 1958, and 1980's, many plants from Phillips' planting plan do not exist today (Spain 1990). Only a few oak trees, palmetto palms, cypress pine and longleaf pines remain.

Gammons, in a letter to the author, described the current landscape as composed of magnolias, mondo grass, camellias, sagos, yaupon holly and azaleas, that evoke a Charleston, in South Carolina, feel. Phillips and Buck shared a passion for using plant 

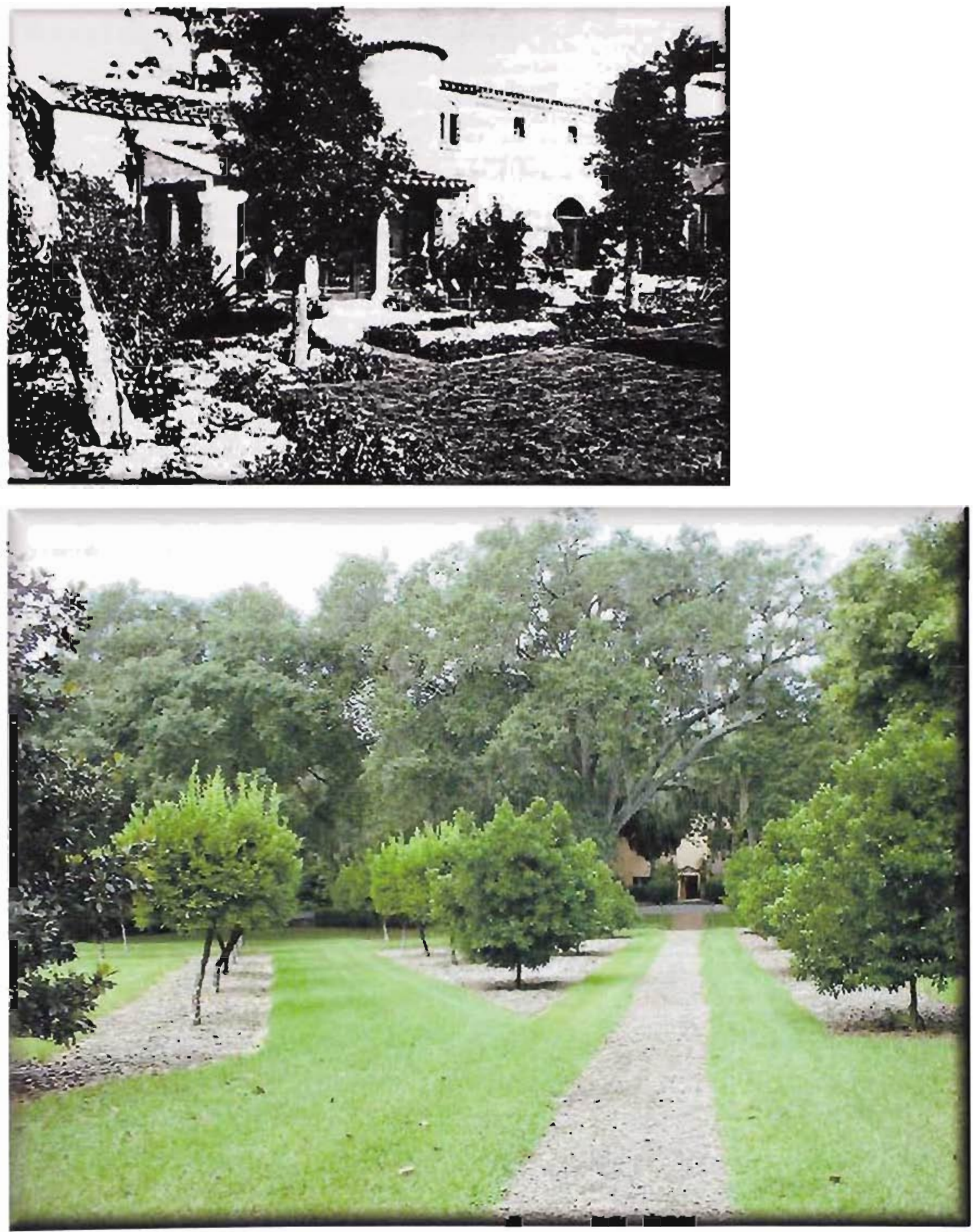

Figure 4.4 - Comparison of past and present views on the east side of the house The above figure is a view of the East Terrace circa 1993, taken from the Buck family videos provided by Bok Tower Gardens. The figure below is the view of the citrus grove today taken by the author. 
material that exhibits more color, like hibiscus, poinsettias, oleanders, amaryllis, agaves, yuccas, roses, bougainvillea, petunias, ornamental bananas, and silk oak.

The overlay shown in Figure 4.5 compares the current vegetation, as inventoried by Gammons, with Phillips' planting plan from 1931. This shows how different the plant material is today, and how little of the original planting still remains. Many of the fruit trees, such as avocados, pomegranates, dwarf blueberries, wild lime, pitcher plant, tree ferns, jacaranda, palm grass, bamboo, and cotoneasters no longer exist.

Today, the garden is more formal around the house. The original vines that covered some of the walls are no longer there. The original color scheme that included shades of red, pink, and white is not longer present (Gammons 2001).

The current conditions of the west lawn are:

- The vegetation in the buffer zone around the west lawn is overgrown and needs to be cleaned out

- The woodland path, as shown on the original plan, is mostly gone, and only a small portion remains around the pond

- The pond vegetation is over grown and needs to be replaced

- The wildflower garden no longer exists. In its place, there is the so-called native garden, which is not very attractive 


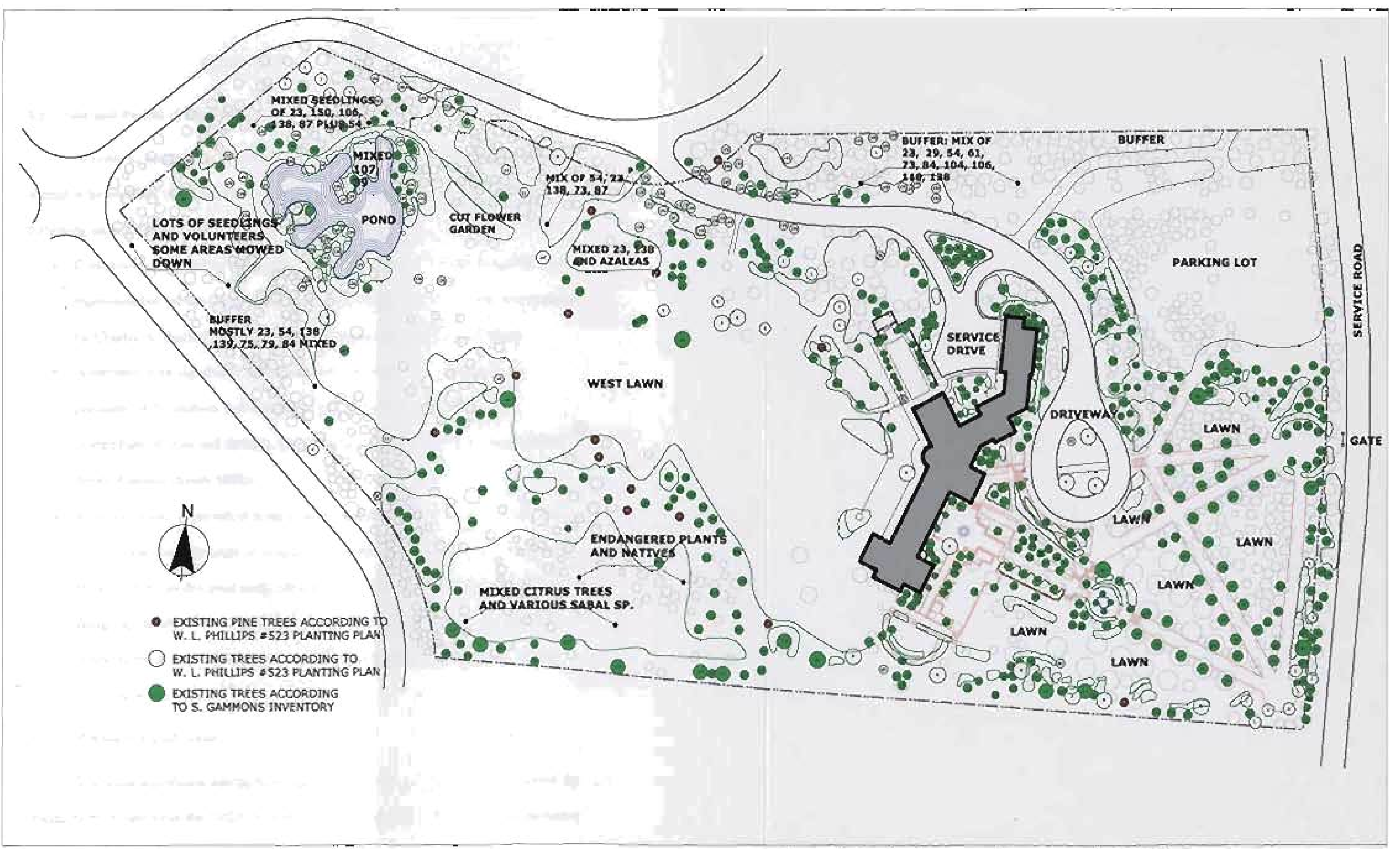




\section{CHAPTER 5}

\subsection{Site and Period of Significance}

In order to establish a criterion for the restoration of the estate and what period should it be restored to, Guidelines for Treatment of Culture Landscape was used. The following aspects of the site were taken into consideration:

- Consciously designed by a landscape architect: William L. Phillips was the local representative for the Olmsted Brothers firm in Lake Wales, when he was retained by Charles A. Buck to prepare the landscape plan for the Pinewood Estate.

- Associated with significant persons: Charles A. Buck was, at the time, the president of Bethlehem Iron Company, and had a special interest in the horticulture of trees and flowers. He also collected exotic seeds and plants from South America (Spain 1991).

- Reflects a cultural/historical trend in landscape architecture: In 1930, while the country was going through an economic depression, Mountain Lake Colony was thriving. Phillips designed many gardens in the Colony during this period. His design approach at Pinewood was to preserve as much of the existing longleaf pines, native to the site, while experimenting with exotic plant material, as was the trend at the time.

\subsubsection{Period of significance}

The most significant period in the garden was when Charles A. Buck visited the estate every winter from the 1930's to mid 1940's. Being a knowledgeable and dedicated 
plants man, he was more interested in horticulture than were the subsequent owners. From 1945 to 1985 , the later owners provided minimal attention and only basic maintenance to the garden (Wallace 1991).

Based on the information from the planting plan \#523 submitted by Phillips in 1931, correspondence between Buck and Phillips about the landscaping plans (Appendix A), and the Buck family movies taken at Pinewood, the period that best reflects the design intentions and the owner's dedication, is around 1935-1940 (Wallace 1991).

\subsubsection{Recommended Treatment}

As in McKee Botanical Garden, many of the historic features are no longer there. Almost none of the original plant material is left today. What was once a garden with masses of flowers, such as amaryllis, petunias, snapdragons, azaleas, bignonia vines, jacaranda, is no longer there (Wallace 1991).

The change in use of the property will have great influence in the treatment that best focuses on preserving the original fabric. Since the property was acquired by the Bok Tower Foundation, its purpose changed from a private garden, used only for a very limited time every winter, into a place open to the public for seasonal tours that run from October to mid-May, as well as meetings, lectures, chamber concerts, and other special events.

Since the property has a new use, of the four treatments under The Guidelines, as outlined in the Case Study, only rehabilitation gives the opportunity to conduct minimal changes in the space, its features and spatial relationships to make possible an efficient contemporary use without destroying the historic fabric. In such focus, the garden can be 
transformed into an educational tool for visitors to be able to establish a connection to the past.

The garden has evolved from a sunny garden into a shady garden with beautiful oak trees (Quercus virginiana) acquiring historic significance of its own, and shall be retained and preserved. By using rehabilitation, this treatment allows to replace shadedout under story with more shade-tolerant species.

\title{
5.2 Program
}

The program describes how the physical facilities of the Pinewood Estate should serve. The mission statement of Bok Tower Foundation serves as guideline to arrive at a program that fulfills the garden's intended purpose and functions.

\begin{abstract}
Mission Statement
"The mission of Bok Tower Gardens, which is incorporated as The Bok Tower Gardens Foundation, Inc., a non profit operating foundation for 'educational, charitable, literary and scientific activities' is to perpetuate the dream of its founder and friends, to present mankind with 'a spot which would reach out in its beauty to the people, and fill their souls with the quiet, the repose, the influence of the beautiful,' and through tree, shrub, flowers, birds, superb architecture, the music of the bells, and the sylvan setting" provide for visitors a retreat of natural beauty, a refuge for the bird, and a place for the student of Southern plant and bird life." (Bok Tower Gardens)
\end{abstract}

\subsubsection{Objectives}

As a result of the previous research and analysis, the history of the property, and the existing conditions, the following specific aims were developed:

- Protect and preserve this historically significant design as an educational tool for future generations 
- Reinforce the original intent of the designer

- Create new uses compatible with the preservation of the historic character to attract more people to the garden, and establish a better connection with the community

- Design a small picnic area by the pond that can also be used for educational purposes, such as poetry classes or watercolor painting

- Minimize the impact of new plant material on the existing ground

- Use the site as an endangered plant species laboratory

- Create a potential venue for special events, such as writers retreats

- Offer educational opportunities in garden programming such as botany, horticulture, garden design, environmental issues and local and Florida history

\subsubsection{Landscape Objectives}

- Restore missing features from the selected period of significance, like the woodland path in the west lawn

- Recreate buffer zones around the property lines according to the original planting plan, to visually isolate it from the adjoining roads

- Replace longleaf pines according to Phillips' planting plan

- Develop a landscape design that is reasonable to maintain, but compatible with the historic landscape design

- Follow the design intent of Phillips, but adapting it to current day practices by:

$\circ$ Using non-invasive planting

- Using more shade-tolerant planting

- Using plants that do not require excessive maintenance 
- As in Bok Tower, provide a habitat for birds and butterflies

- Enhance the existing pond by:

- Adding visually attractive planting materials

- Adding water lilies to improve water quality and add color

- Thinning out existing trees to allow more light into the pond

- Eliminating invasive and overgrown vegetation

\subsubsection{Access and Circulation Objectives}

- Improve the pedestrian linkage from Bok Towers Gardens to Pinewood Estate

- Develop a handicap accessible woodland path around the west lawn, allowing access similar to Phillips' plan

- Create interpretive walk with different points of interest around the trail

- Create different points of interest along the path

- Design a parking area for special events, with capacity for 30 vehicles

- Create a buffer zone around the parking area, so it is not visible from the house

- Provide a fully accessible path from the parking area to the entrance to the house

- Create a new discreet service entrance in the south side through the buffer zone for easy access for trucks and trash pick-up

\subsection{Conceptual Design Description}

Figure 5.1 illustrates the proposed conceptual design for the Pinewood Estate gardens. Because rehabilitation was selected as a treatment, the main features that define the spatial organization are maintained and complemented with elements that respect the overall pattern in the cultural landscape. 


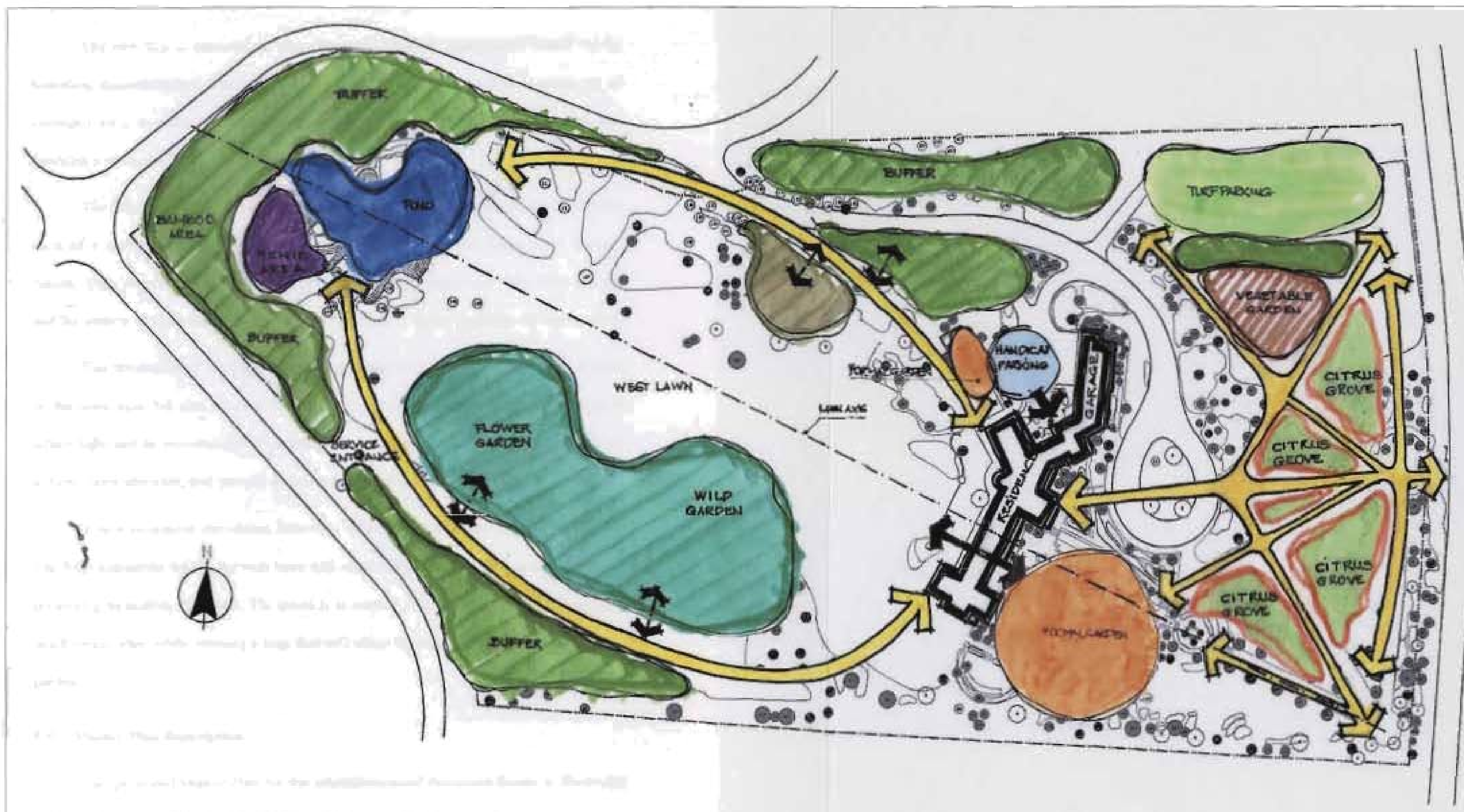


The new use is intended to complement the spatial organization based on the historical documentation. The Italian Renaissance style citrus grove is designed on an extended axis, in order to tie in the proposed parking lot and vegetable garden, and establish a connection with the house.

The vegetation in the buffer zones and the citrus grove should be restored since most of it is missing. These should be compatible with the habit, form, color, texture, bloom, fruit, fragrance, scale, and context of the historic vegetation. The color scheme and the variety of plant material should reflect Charles A. Buck's passion for horticulture.

The restoration of the pond is very important, not only because it is a focal point on the main axis, but also because in Phillips' designs water was a prominent feature to reflect light and its surroundings (Jackson 1990). Creating an area of activity is important to both, draw attention, and provide a reason for maintaining it.

A new pedestrian circulation following Phillips' design intent will be established. The fully accessible trail in the west lawn will adapt to the new requirements while preserving its historic character. The intent is to connect the house with the pond and a small picnic area, while forming a loop that will allow the visitor to enjoy the entire garden.

\subsection{Master Plan Description}

The proposed Master Plan for the rehabilitation of Pinewood Estate is illustrated in Figure 5.2, and can be described in terms of three basic components: 


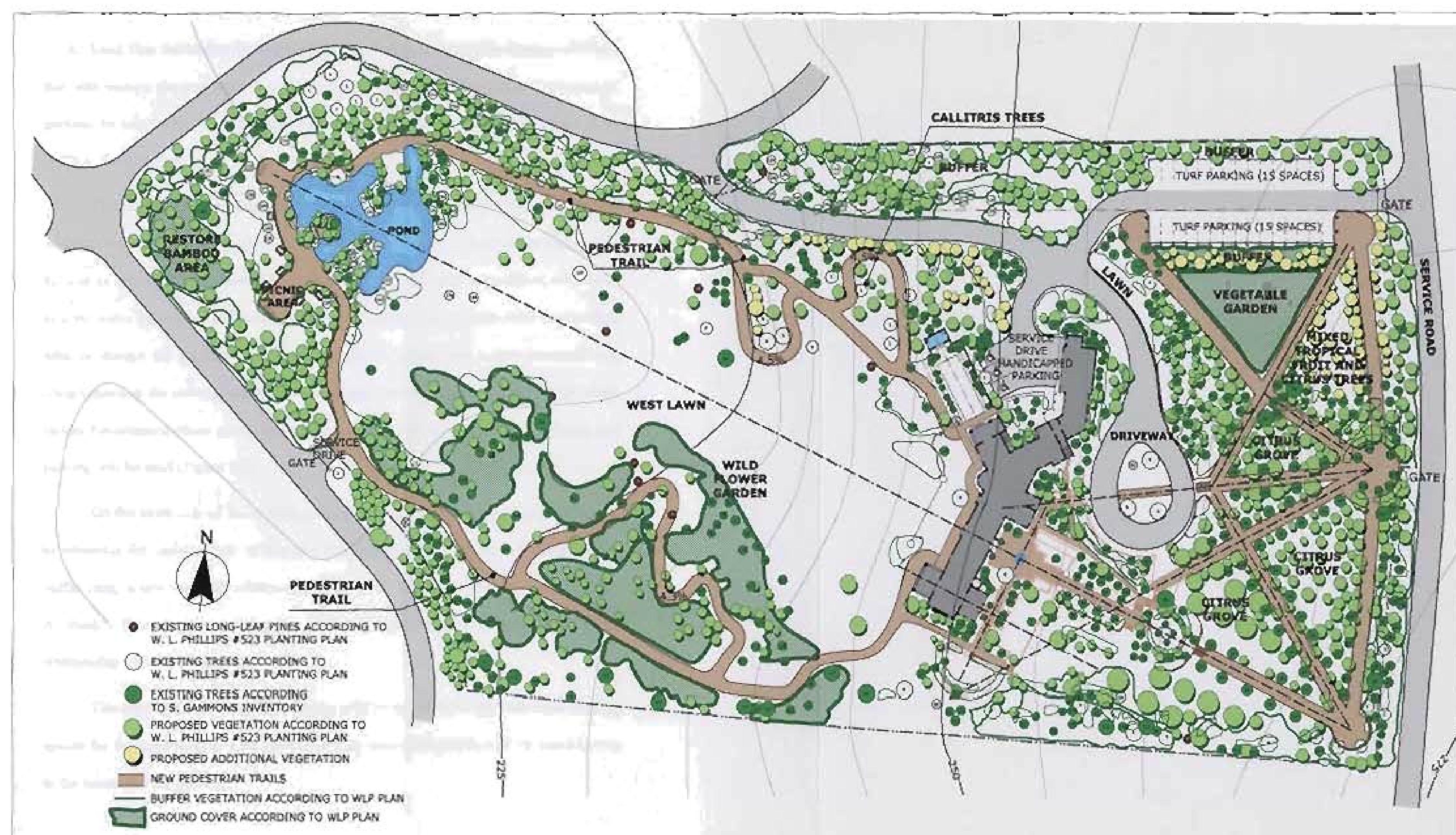


A. Land Use: establishes the location, size, and relationships of the various activities that will occupy the property. The master plan proposes that the existing structure of gardens be continued and expanded. The new use of the property is integrated with Phillips' design criteria.

The proposed parking area for 30 vehicles is located on the northeast corner of the property, with its main access from the service road adjacent to Bok Tower Gardens. It follows an axis already established in Phillips' plan as a secondary circulation, and serves as a vehicular connection to the existing main driveway. This location does not interfere with or disrupt the gardens. It is connected to the house with a new extended axis complementing the existing pattern of avenues and roundels, as in Phillips' design of the Italian Renaissance citrus grove. In order to minimize the amount of hard surfaces, turf parking will be used (Figure 5.3).

On the south side of the parking area, new dense buffer vegetation will be created to minimize the visual impact of this area from the house and gardens. Adjacent to this buffer zone, a new vegetable community garden that reflects the same use as in Charles A. Buck's time is proposed, but has a new purpose, that is to establish a closer relationship with the community.

The service drive west of the garage will be modified to provide three parking spaces for the handicapped. This location is very convenient because of its direct access to the house and the gardens. 


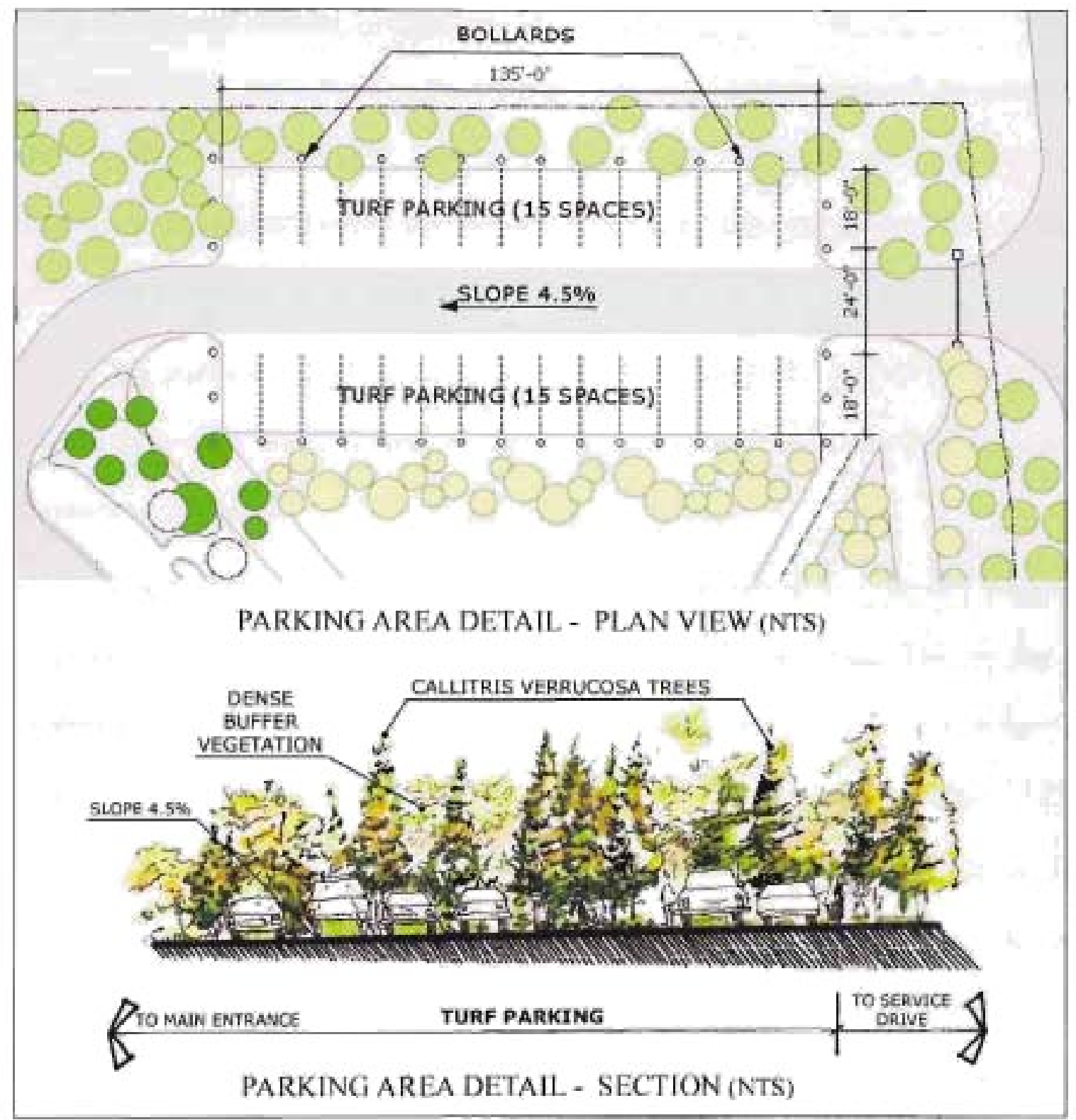

Figure 5.3 - Detail of proposed parking area

Source: Drawings by the author 
B. Access and circulation: The main vehicular access from Mountain Lake Colony to the house will be retained. From the driveway, leading north, the access to the parking area is improved, maintaining the character and scale of the property. The service entrance on the east side of the driveway will be enclosed with vegetation to prevent the view when the visitors come in the driveway (Figure 5.4).

The pedestrian circulation from Bok Towers Gardens is through the citrus grove located on the east side of the property. The avenues connect to the circles or to the main entrance of the house.

Since the house is located on the same level as the garden, there is a close connection of the east terrace with the frog fountain and the grotto. The proposed woodland path starts from the east terrace and leads the visitor around the west lawn. This path is built on a stabilized crushed stone surface for ease of circulation (Figure 5.5).

The trails, as included in Phillips' original design, have certain areas that would not meet the minimum requirements for handicap access, due to the substantial change in elevation of the existing garden. The proposed trails address this issue, in addition to retaining Phillips' design intent, by following a main path substantially similar to the original, but adapting to some of the existing vegetation, complemented by secondary trails that stem from the main one to allow for a longer development and therefore a handicap accessible slope of $4.5 \%$ or less. The secondary trails will also give the visitor the opportunity to enjoy more varied and densely vegetated areas of the garden. The trail on the south side of the property will be extended from the original design towards the house, to complete the loop and allow for a connection to the east terrace garden. 

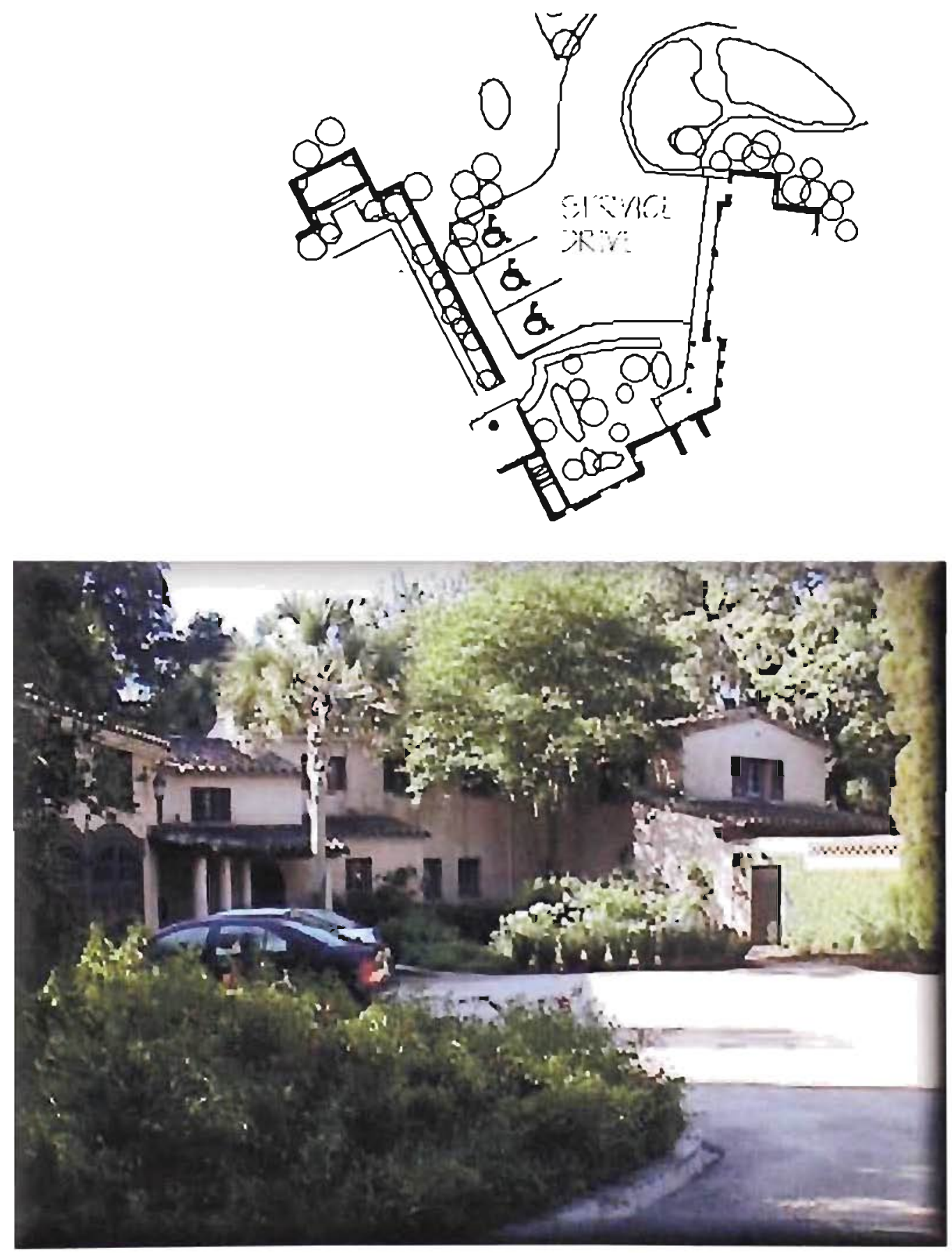

Figure 5.4- Service entrance with handicapped parking area Source: Photograph by the author 


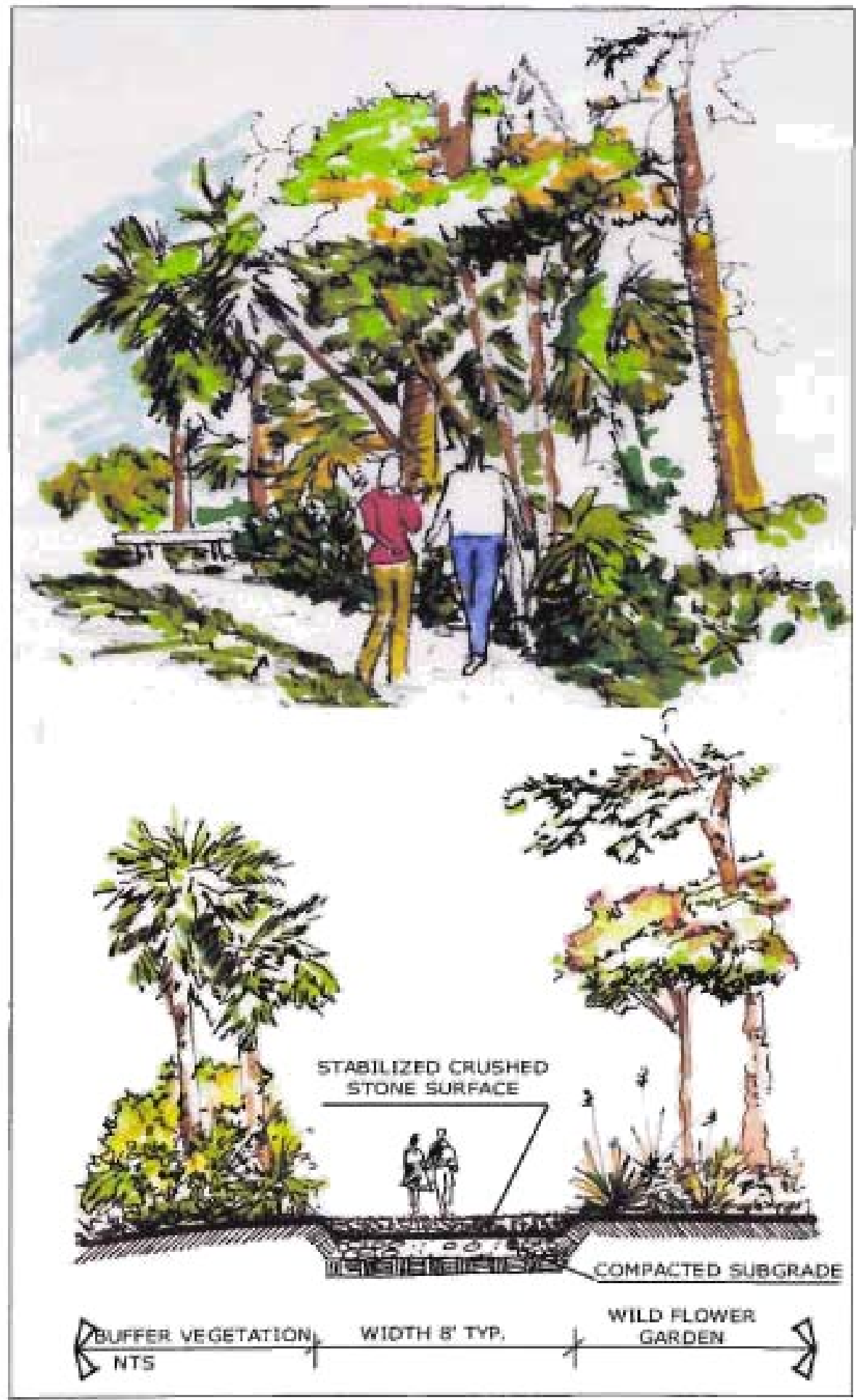

Figure 5.5-Tral details

Source: Drawing by the author 
C. Landscape Form: the landscape proposed for the garden can be defined in different zones:

- The citrus grove and tropical fruit trees: The existing citrus trees on the southeast side will be preserved and complemented, according to Phillips planting plan \#523, with different variety of citrus such as orange, grapefruit, lemon, tangelo and fruit trees such as loquat, as shown in Figure 5.6.

The citrus grove on the northeast side has a different variety of citruses combined with very different trees such as eucalyptus, acacias, litchi, and jacaranda.

- The vegetable garden: The vegetable garden shall be planted especially for children to create awareness of the environment.

- The buffer vegetation on the north and east boundaries: This area should be restored with cypress pines, carolina cherry, and silk oak according to Phillips' planting plan.

- The west lawn: In this area the existing landscape is preserved and enhanced with different points of interest compatible historic landscape design composed of:

○ The wild flower garden: this is a very important element to restore the color missing in the garden. The agaves and the ground cover are elements that should be restored. Some of the flowering trees such as the silk oak, bottlebrush, acacias, and camphor would add color to this area. The existing native longleaf pines are preserved and the missing according to Phillips' planting plan should be added. 


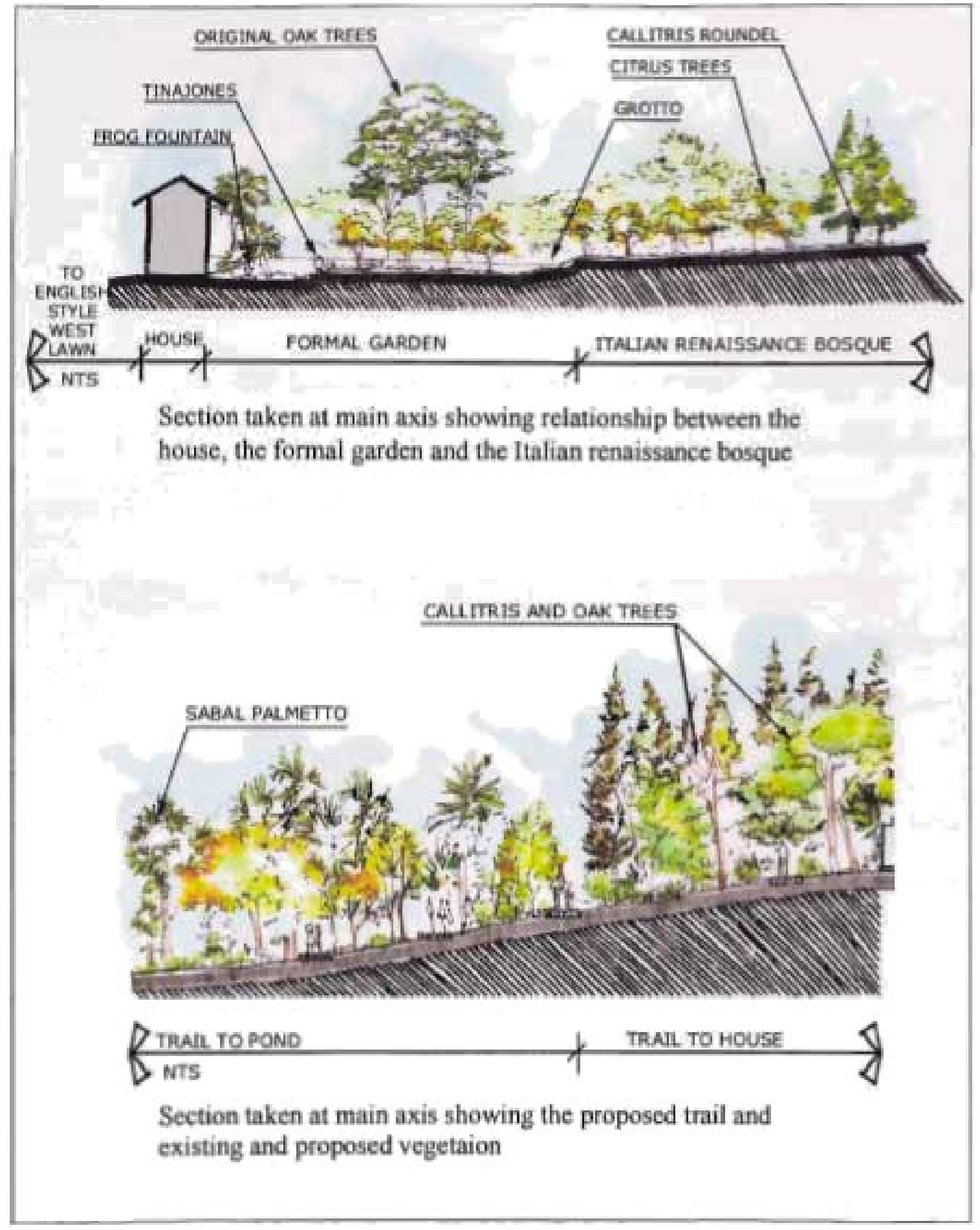

Figure 56 - Sections taken at the main axis Source: Drawing by the author 
- The pond: Cabbage palms, wax myrtle, oak trees and yaupon holy are predominant trees around the pond area. As shown in Figure 5.7, the existing vegetation will be thinned out to allow more light in this area and water lilies will be planted in the pond to add more color and reinforce the pond as focal point attracting visitors down to this area.

- The bamboo area: Since this area is right behind the pond, the restoration of the bamboo area is important, since its add the tropical look Buck was so fond off. It is very attractive and a good buffer vegetation.

- The Callitris verrucosa trees on the north side of the trail: as the trail takes the visitor around the garden, the callitris verrucosa trees are an important element in Phillips' design, since it reflects the Mediterranean look, so popular during that time, and therefore should be restored (Figure 5.8). 


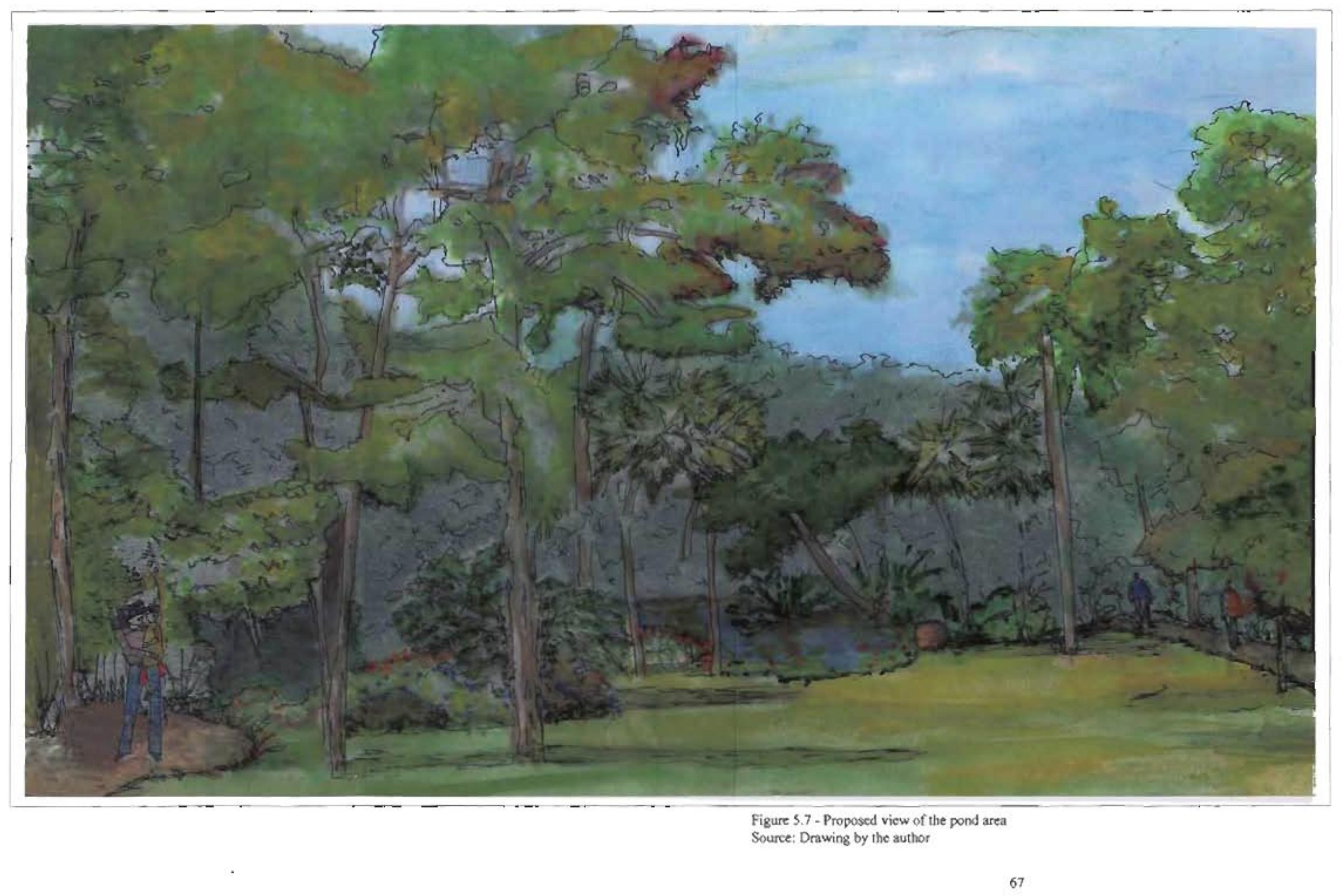




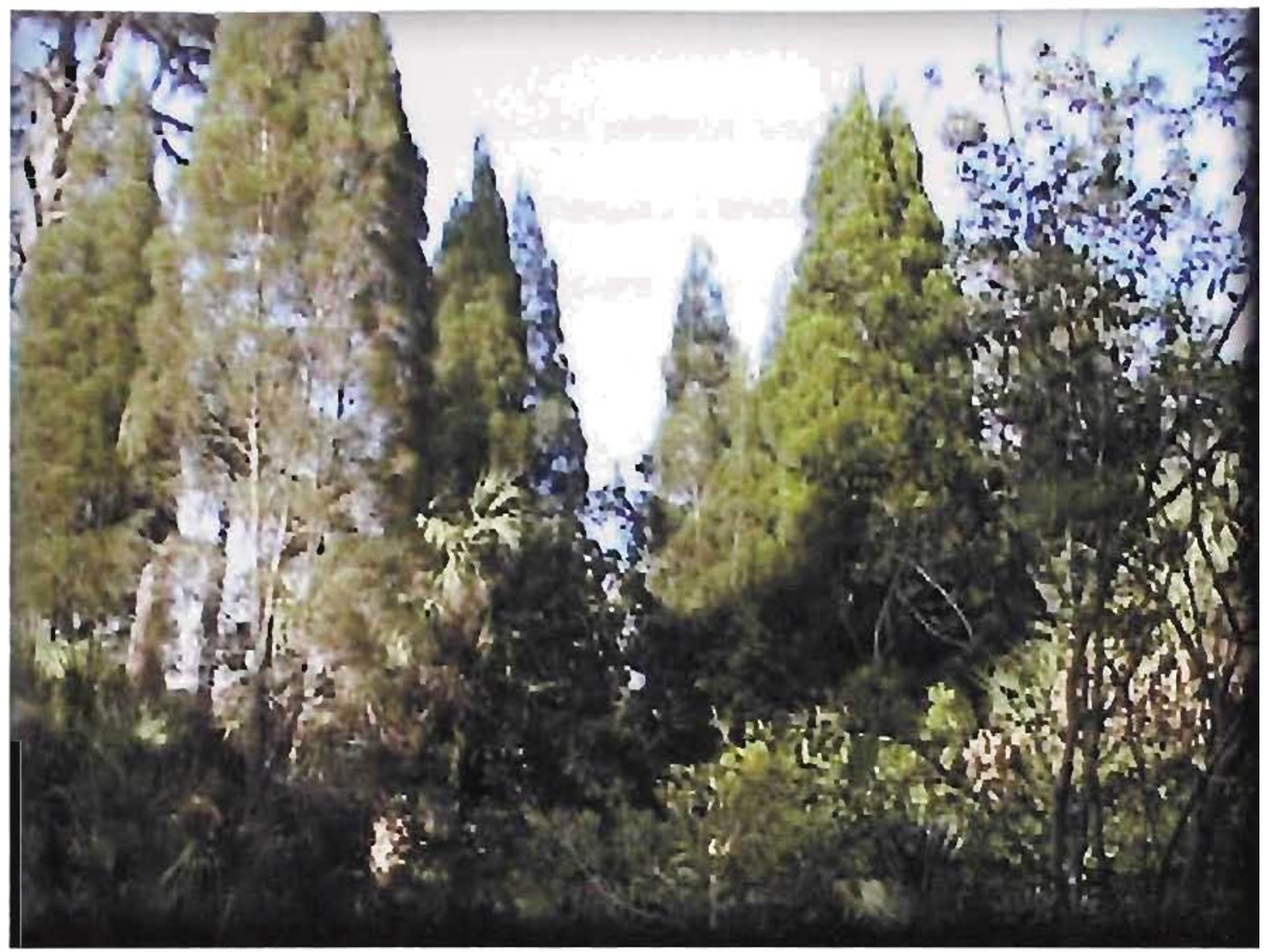

Figure 5.8 - Callitris verrucosa trees

Source: Photograph by the author 


\section{CONCLUSION}

Historic landscapes are cultural resources as important as historic buildings and districts; they are an expression of a particular timeframe, cultural richness, and a changing relationship with the environment. Unfortunately, historic buildings have a greater survival rate than cultural landscapes since nature is ephemeral and constantly changing.

This thesis provided a landscape plan that will rehabilitate the Pinewood Estate to its historic integrity in order to retain and reflect its past. Of the four preservation strategies established in the Guidelines for Treatment of Culture Landscapes, rehabilitation was determined the most appropriate for this thesis project. The period chosen to rehabilitate the garden that best reflects Phillips' design criteria, was when Charles A. Buck visited the estate every winter from the 1930's to mid 1940's. Through this rehabilitation process, all significant features were retained and preserved while permitting improvements that allowed for contemporary use of the garden, such as handicap access and additional parking. The physical change will help the potential growth and preservation of the estate in the future.

Retaining and preserving the Mediterranean Revival style accomplished the primary goal of rehabilitation. William Lyman Phillips achieved in this garden an important synthesis of his own eclectic style, incorporating diverse stylistic elements such as the Chinese moongate, and the English picturesque with follies that frame the vistas, construed with Moorish and Italian Renaissance garden elements. In order to bring back 
the Mediterranean look, the Callitris verrucosa trees and tropical vegetation is restored according to his planting plan.

Being involved from the beginning in the site planning of the estate gave him the opportunity to take into consideration the existing vegetation and the best views from the house. He enhanced vistas so that the estate seems more expansive than the actual 7.59 acres. The backbone of his design is the use of the axial vistas defined by focal points such as the pond. Through this research, this area is redesigned with new uses and interest points inviting the visitors to connect with nature.

This rehabilitation attempt through this thesis recognized William L. Phillips' inspirational, peaceful, inviting garden as complement to the activities normally carried out at Bok Tower Garden, but within a more intimate environment.

The garden of Pinewood Estate combined with the numerous other Phillips work throughout Florida, constitutes an important body of work in the history of American landscape architecture.

\section{FUTURE RESEARCH}

Continued research should be undertaken to help maintain Pinewood's estate as sustainable despite the vagaries of the economy.

The documents of Olmsted Job \#6023 are located in the Library of Congress in Washington; D.C. (Appendix E) should be electronically accessible. This file contains besides the plans and drawings, the correspondences between the Olmsted firm and the client. This is valuable information since they explain the design intent and details used in the project. 
Since Phillips and Buck were so involved in horticulture and introduced exotic plant material from different countries, more research should be done on plant material and horticulture practices during that period, to avoid invasive species such as cherry laurel or brazilian pepper to take over. This information should be used to decide what plant material should be restored according to the planting plan \#523.

People involved in the maintenance of the garden during Charles A. Buck times, such as friends or descendents that frequented the estate, family members, former horticulturist Susan Wallace and David Price, director of Bok Tower Gardens should be contacted. 


\section{REFERENCES}

Birnbaum, Charles A. 1996

Guidelines for treatment of Cultural Landscapes.

Washington, D.C. Library of Congress.

Birnbaum, Charles A. 36 Preservation Briefs

http://www2.cr.nps.gov/tps/briefs

Birnbaum, Charles A. 1992

Focus on Landscape Landscape Preservation

Preservation Forum, Volume 7, No. 3

Washington, D.C. National Trust for Historic Preservation.

Beveridge, Charles E.,and Rocheleau, Paul. 1998

Frederick Law Olmsted

Italy, Universe Publishing.

Caldwell, John W. 1984

Mountain Lake: A History.

Lake Wales, Fl.,Mountain Lake Corporation.

Eliot, Charles. 1971

Charles Eliot, Landscape Architect

New York: Books for Libraries Press.

Favretti, Rudy J. 1990

For every House a Garden:a guide for reproducing period garden.

Hanover, $\mathrm{NH}$ :University press of New England.

Favretti, Rudy J. 1978

Landscapes and gardens for historic buildings

Nashville, Tenn.: American Association for State and Local History.

Favretti, Rudy J. 1991

Master Plan Restoration Plan: Pinewood.

Storrs, Connecticut.

Gunn, Fenja. 1991

Lost gardens of Gertrude Jekyll

New York : Macmillan : Maxwell Macmillan International.

Goulty, Sheena Mackellar. 1993

Heritage gardens: care, conservation, and management

New York, Routledge. 
New York, Routledge.

Hudak, Joseph. April 1955

Nine Decades of Landscape Design 1857, F.L. Olmsted Sr. Olmsted Brothers, 1955. Landscape Architecture (45:120-33)

Jackson, Faith R. 1997

Pioneer of Tropical Landscape Architecture.

University Press of Florida.

Jackson, Faith R. 1990

An eclectic American classic is being called out of retirement

American Horticulturist Society.

Jellicoe, Geoffrey and Susan. 1995.

The Landscape of Man

New York: Thames and Hudson,

Kirk, John. C 1925

The Vinoy Park Hotel: History of its Building and Furnishing.

St. Petersburg, Fl : Press of Cashwell-Cooke and their partners.

Lombard, Joanna

The Memorable Landscapes of William Lyman Phillips

Historical Museum of South Florida

Myers, Ronald, and John J. Ewel. 1990.

Ecosystems of Florida

Gainesville, Fl. University of Central Florida Press.

Newton T., Norton. 1971

Design on the Land.

Harvard Univ. Press, Cambridge, Mass.

O'Connell, Kim A. June 2001

"From Myth to Reality."

Landscape Architecture (88-89)

O'Connell, Kim June. 2000

"Care of Character."

Landscape Architecture (28-35)

O’Connell, Kim. 2000

"Just Rewards."

Landscape Architecture (35-37,82-84) December 
O’Donnell, Patricia M. 1993

The Treatment of Historic Landscape

Washington D.C. The Journal of the National Trust for Historic Preservation.

Phillips, W.L. and E.C. Whiting, April 1958

"Frederick Law Olmsted- 1870-1957: An Appreciation of the Man and his achievements."

Landscape Architecture (48:144-57)

Reyburn, Susan. 1999

Garden and Landscapes

Washington D.C. National Trust for Historic Preservation

Scofield, Julie Adams and Thomas W. Scofield. 1984

Pinewood: Architectural and Historical Significance.

Spain Schwarz, Rebecca. 1991

Pinewood House and Garden

St. Petersburg, Fl

Tankard, Judith B. 1989

Gertrude Jekyll : a vision of garden and wood

New York: H.N. Abrams/Sagapress

Wallace, Susan. 1988

Pinewood's Historic Gardens

Lake Wales, Fl: Bok Tower Gardens,

Wallace, Susan. 1991

Notes of the restoration of Pinewood Gardens.

Zaitzevsky, Cynthia. 1997

Fairsted : A Cultural Landscape Report for the Frederick Law Olmsted National

Historic site

Boston Mass, National Park Service and Arnold Arboretum,

The National Register of Historic Places

www.nps.cr.gov/nr

National Trust for Historic Preservation

www.nationaltrust.org

National Park Services

www.nps.gov 


\section{APPENDIX A}

Letters from William Lyman Phillips to Charles A. Buck. 1929-1932 


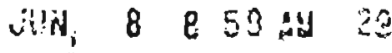

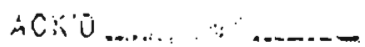

$$
\begin{aligned}
& \text { a! }
\end{aligned}
$$

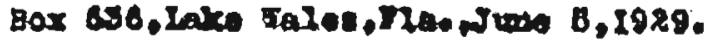

:tr.0.4. trook.

Bothlohon 8toul Compang.

Eatblahan, Ha. $_{0}$

voar 36" Bwok,

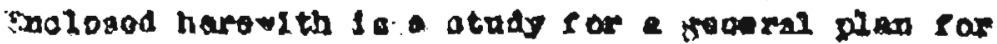

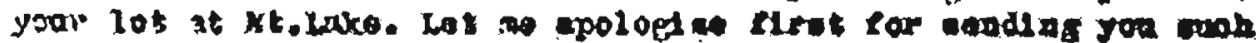

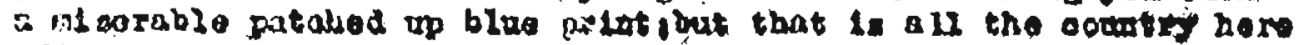

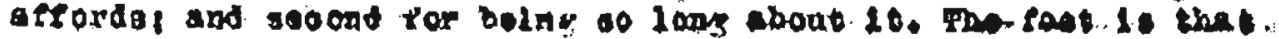

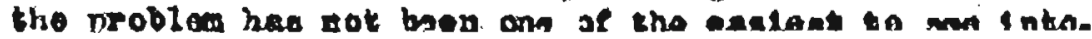

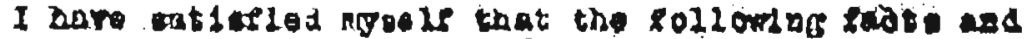

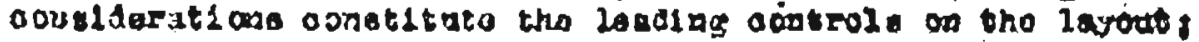

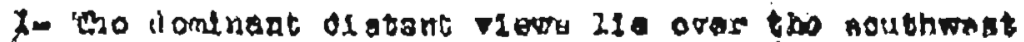

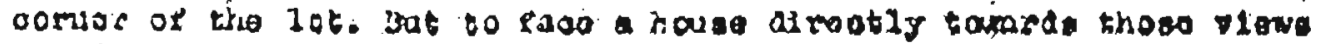

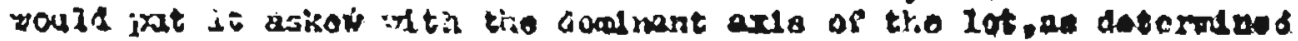

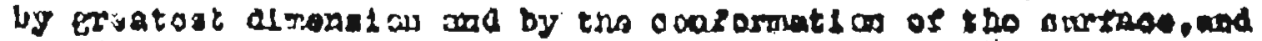

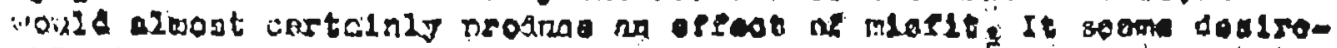

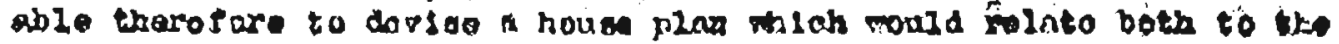

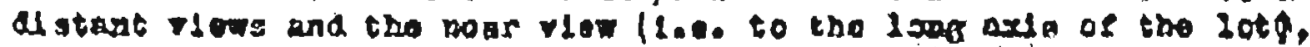
bat hasiag ita cond noxt mas solated to the zaties:

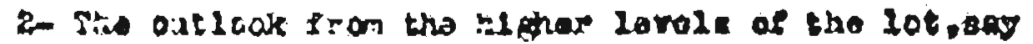

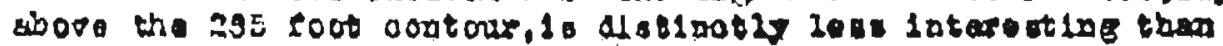
at lomer levelo oulag to the sast that at tho hldper levols the vlews both of the distant landesupe and of tho lower parts of the lot 1ta01:1 ary blooked off by tho tope of the plno teoes.

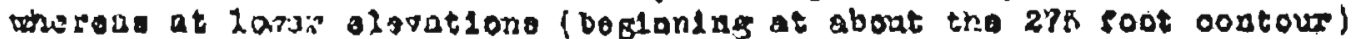
gou lowk out ander the troo tone betwoea the trunice of the plaes, Th1. Eoj81durats on loade no to thlne that tho ronterly side of the

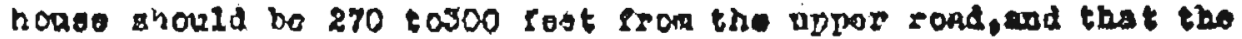
houso floor la that looation olwoild bo alose to the oxdeting oursace as osarablent.

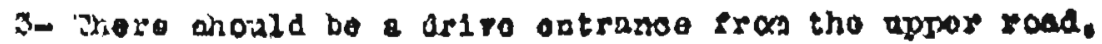
taxloz off it at as low a polat (an fai to tho narth) eo the oxistIng troes 11 l parmit. A second drite ptoring from the peloosted copportition road and mualug olose to your northorly boundary aysoste

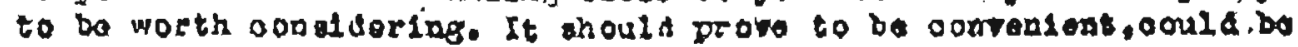

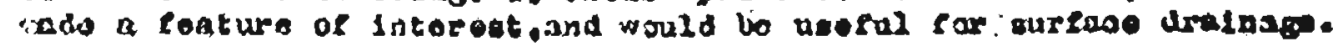


4- The best ponoral sahom sor tho pluce appeara to bo to troat the area bolow the house as a broed laformal lowa, kgoplags all

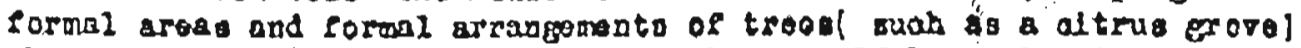
abore the houdo tersace. T:e laformal lars oould bo onolosod by planted

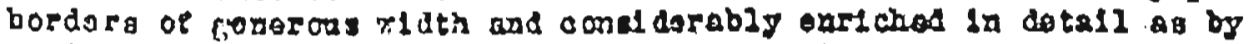

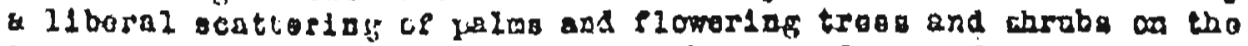
incor olde,tho mass of tho plantlags belag us of native planto. on tho northerly and scruthorly aldos those borders may for tho woot part bo dense enouph to prepont paogerg-by from looxdng in, con the southerly oldo, liowever, there tho adjolnges property bolamge to tho Semotuary ond

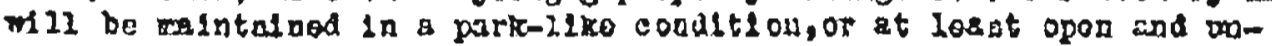
busit on, it wozld locloal aot to express ang defind to boundarg brat

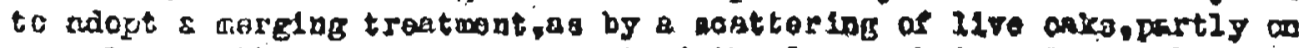
your lot, partiy ou tho Swactuary land, tho latter bolog planted by tho sancturiy as ocule divibtless be arrenged for.

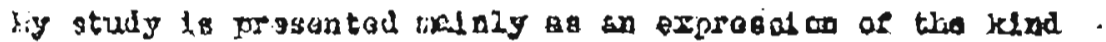

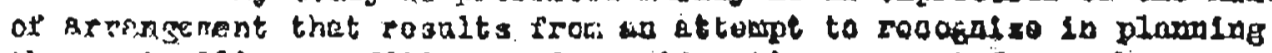
the ontrolleg condsticas and conolderstions 28 set forth abover in wo far 2 a tho trontment of the lyoer part of tho lot to oonoorned

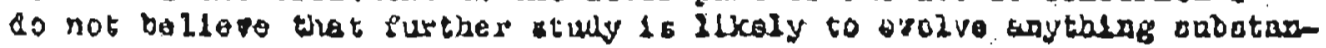

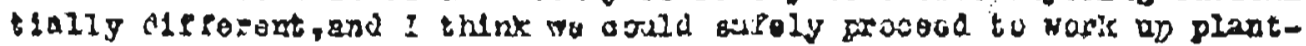
InE plans and do soke planting thl sumer. Wo conld oven astabliah a oent lgodo grags lawp,por on the larer part os tho lot thore appoars to Do vo grade chaman in grouject otiar bua tio oblitorutios or tho

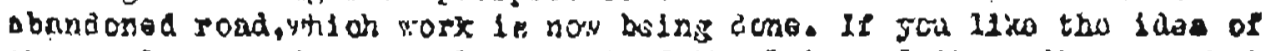

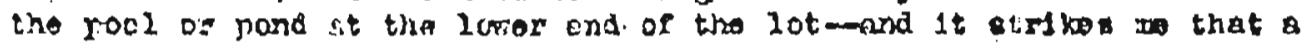

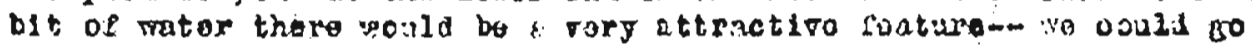
aroad -1 th that.

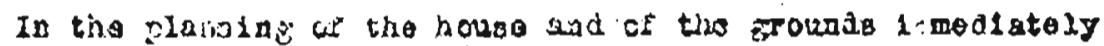

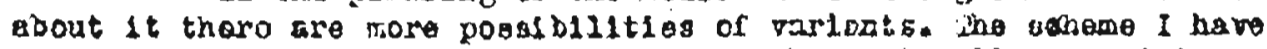

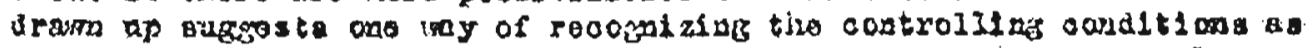

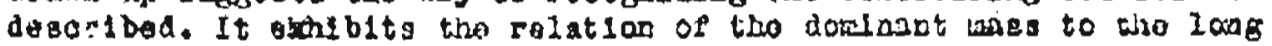
axis of the lot, the bringlap of uho totel hoase rass into rolation to

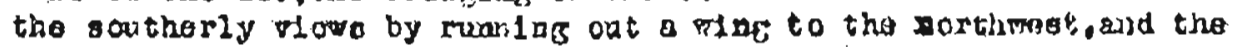
rooonclilation of tho obliquity of the bouse to the boudardos of the

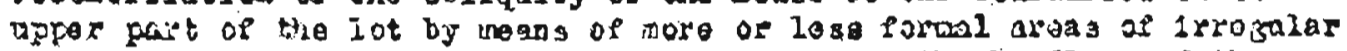

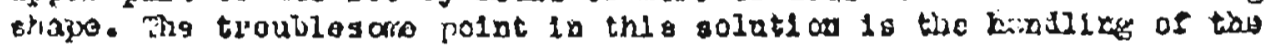

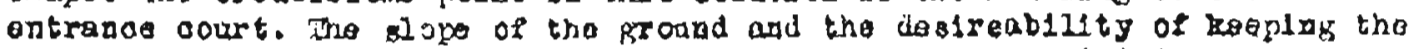

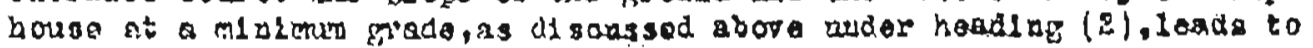

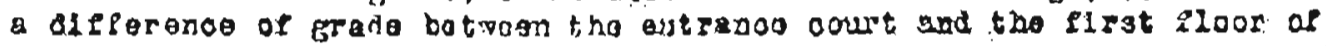
the house, a difsarence of 6 loot in tho prosent gotiaxo. 'Ho drito and the back aldo of the forocourt woald bo out into tho sarfaco, the aldee of the

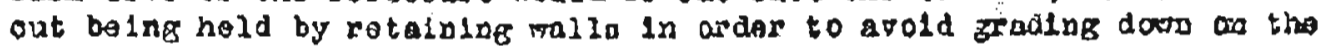
plae troog. i'y thought is to oarry thl walling around the south ead rest alde of the ocart.tgling it on to the house by the roofol entranco

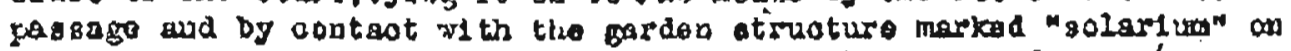

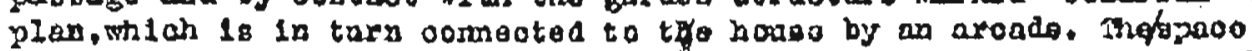
botwoon the ocurtyard rall and the llfing room, baolosed an tho south by the alcado and oolarian,oould bo troated an ands patto. tho rean

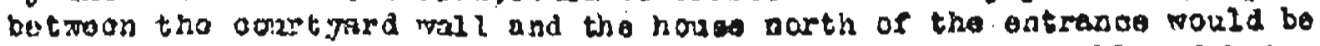

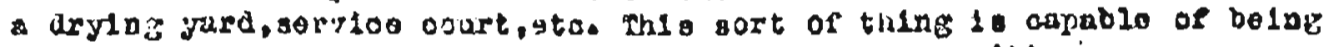

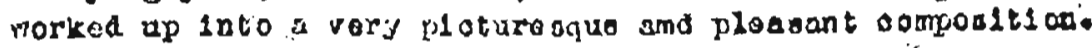




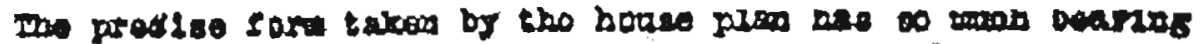

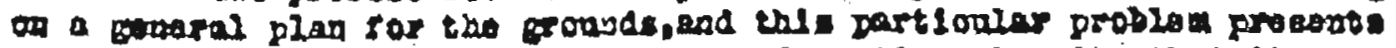

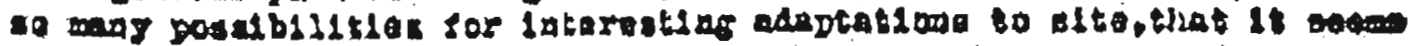

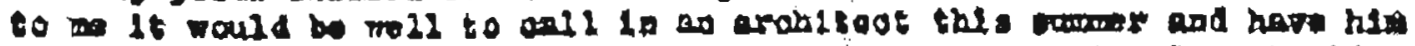

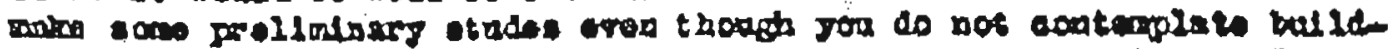

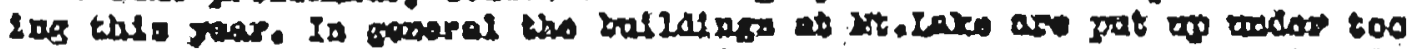

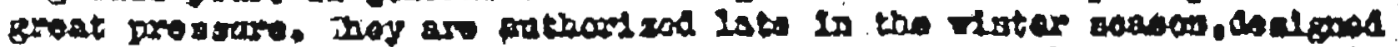

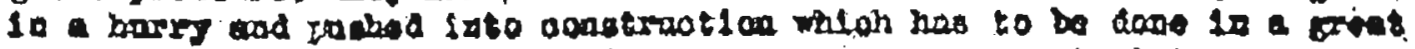

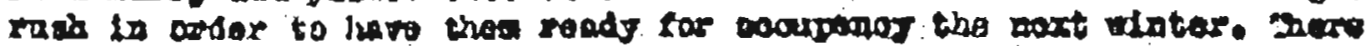

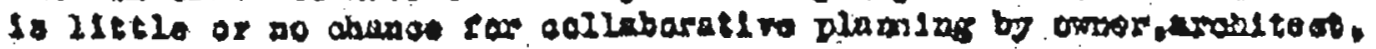

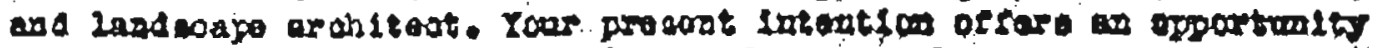

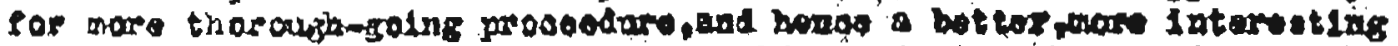

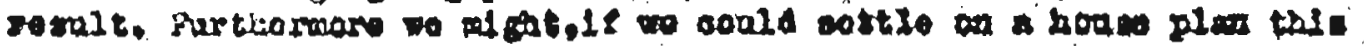

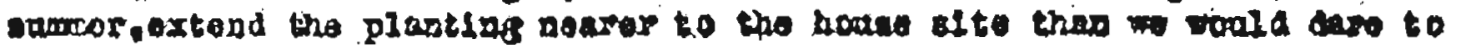

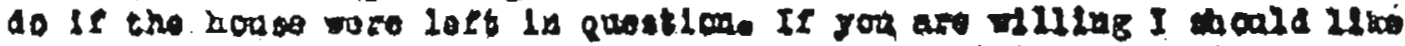

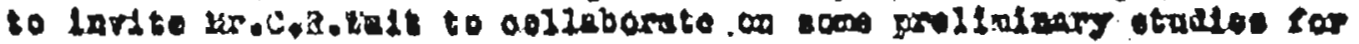

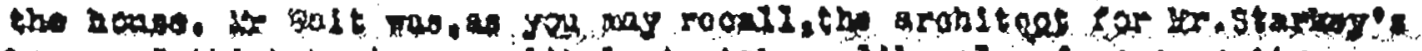

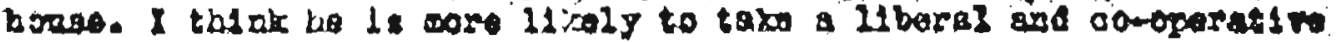

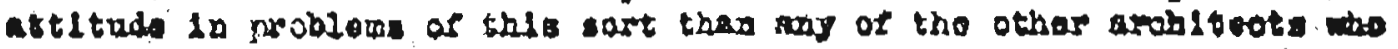

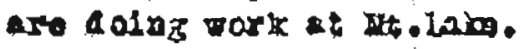

1 whoald of ospres arpreclato eng oxpresal on of soor rom

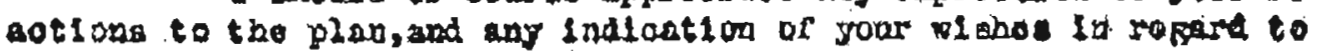
pea ulatapy doreliprootate.

Sincbre Iy yaur.

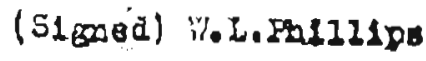

copg to Brooklino

cal1f. 


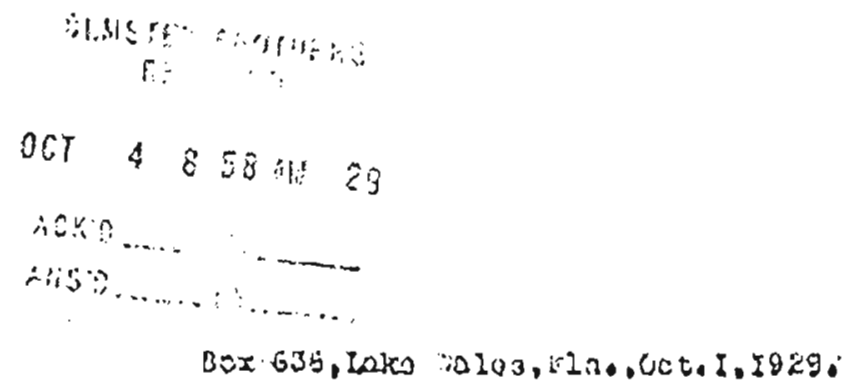

Sring Bnoks

Bechial:on, Po.

iun: j:o . Blacic,

I wa ploased to 20a:n that you 11 iod tho whosin. ror your plito at hit. Loke and aro es erobol to conoldor it fur-

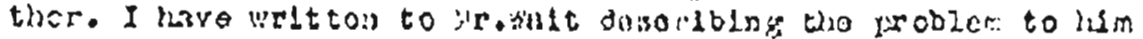
asi) nsklng nlm to sond yout diract tise latonnatlonryou deslre reigl =Uluse hlo POOD.

cup onl chargeo aro not ugunliy tado ord a $f$ lxod cos or forcentane baule, but ano dotormina acconll $n_{i}$ to tho coat

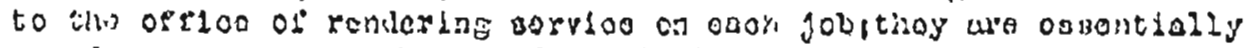

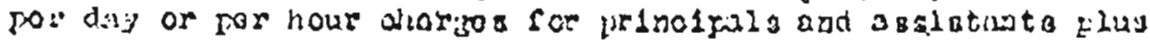

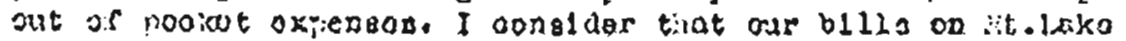
woric sizn'lnir tho construstion perlod vill not normaliy axcoud

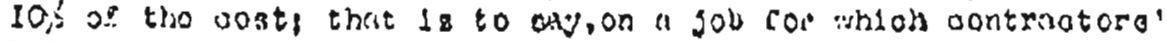

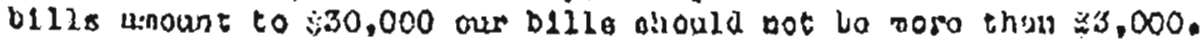

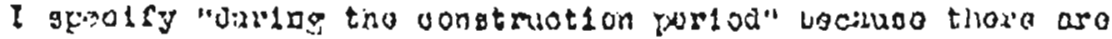
caperul blacos wiolo we liavo raralned la a sort of alrorvlocry

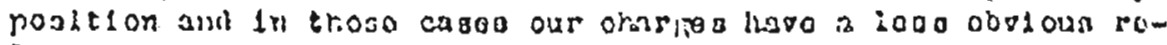
lntlou to outlinyn tiat may lo rndo nubooquod to sho lnitlal lovelonimint.

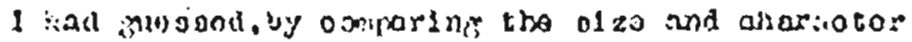

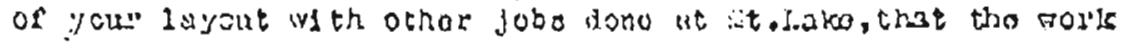

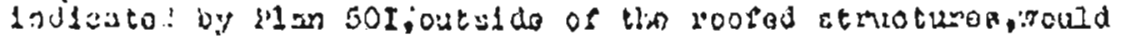

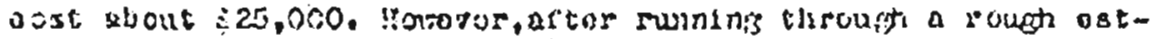

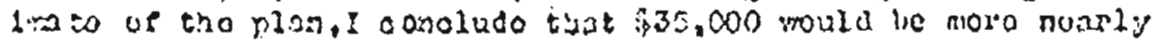

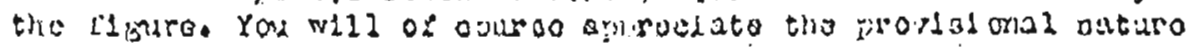
of tho plan and tho fact that this is a pony apyraxi d to ostipito. I ar onclosing a oopy of It oo that you may ono hor tho oosto

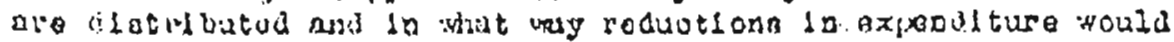
at"eret enu oharowtor of the lajoute

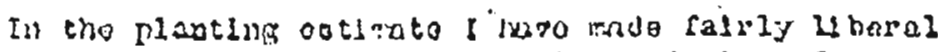

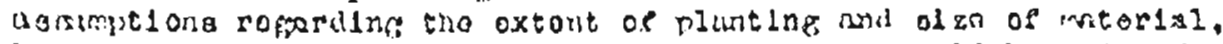

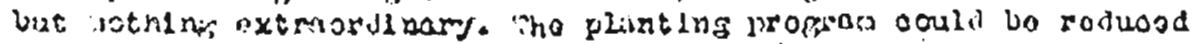


soricohat is to oxtont and as to olzo or matorial, or it could bo Incroasod. Your piogerenco must bo tho puldo thoro, thoogh It la salr to posnt out that wo waro a 31 zablo aroo to tioat,

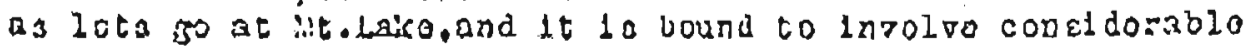

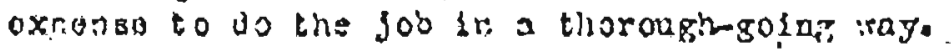

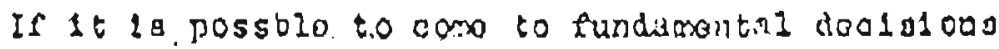
soon 30 tirit no could do somo planting thia fall I can soo adracitasoa in doing so.tall and olutor plantsn; la docldodzy thy boot and most eoonomical zar almost ororythine oxceit palng und if na asano you latend to bulld for cocai ancy in the 30ason 1930-3I you wald bo able to como to a ralrly wollostablished nlavo.

3lacoroly jous,

(\$1gned)

Copy to Broarl1ne

Cal1f. 


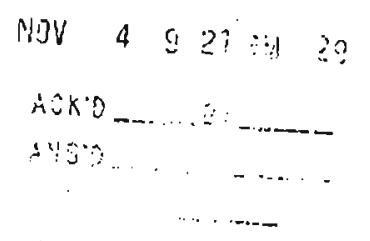

Box 636, Laze Hal4*,32a,, Uot.30,1920.

iv. 0.A.Buok,

Bethlehem, Pa.

Doar Lr. Buok,

soting upon your lottox of oot.7th we have woriced out general plantlob sonome (\$502, orelosod herewith) gor tho loror part as yous lot,and on a weparato aheot (1) b03) have indloated the party or that schome vinlon sosto worth will lo to uedertake this a rall.

The latter pian oontomplated creating ith rolutire

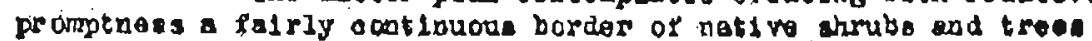
around the outhorly and lower woterly adges of the proports. To

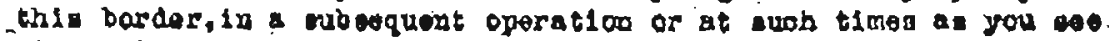
P1t, would bo suded palm and variaus otbor troos and chrubs and

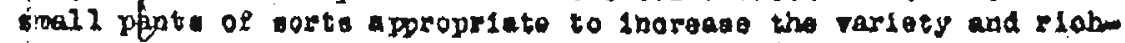
gen of form and coloe in the plantatlan. This prosechuro is baced on the saot thit border mdo up aolols of naroerg stook aro slow to toke on aporoolablo holpht and bell and aro pelativoly exponal Hy plantioy a srassonofx of oolloctod ontorlal at thl timo of yor

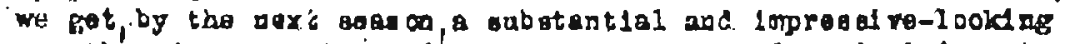

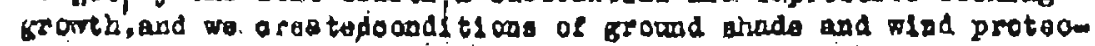

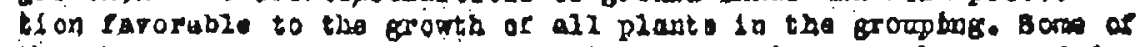
the. things in tho plantlags of native aterial aro to be regarded

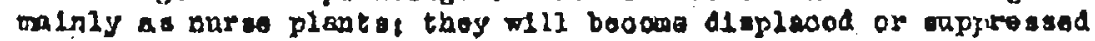

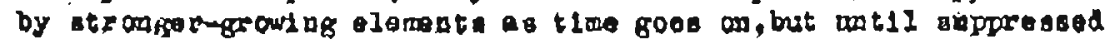
they omotrlbute thels mare to the amolloration of oultural cand1-

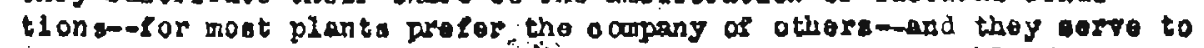

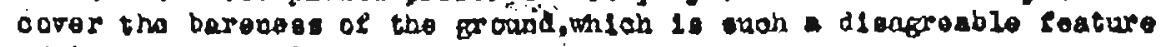
of 1 mature mosolagon

On plom 603 you $\times 121$ notloe that tile mess plaptsags

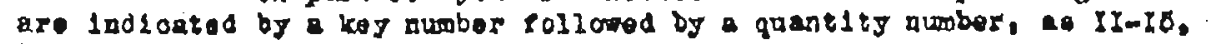

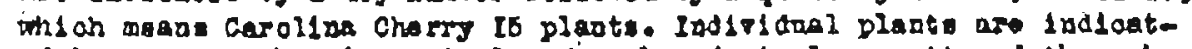

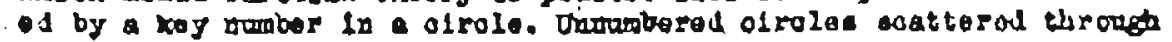
the bede deatgnate 20oationg for trees to bo planted later to gederal aodordanoe ofth plad 602, and poos will bo left ror them in tho flrat planting.

I oonglder it dealrable to undertaxo ths proliminary 
playting ths. Pald bechues I have sound the plantlage of oolleated material do betior under Pall pladtag than at ang othor senson.

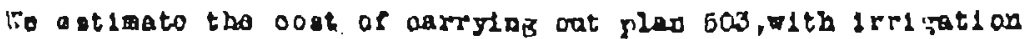
plpos as Indlosted,to be as rollowes

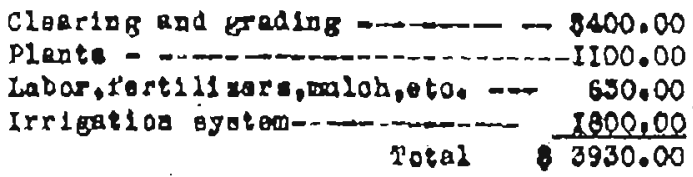

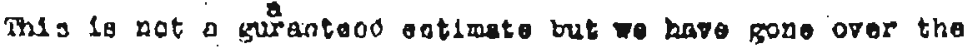
plone with the lit. Lake Corporat1 on plant 10p dopartment and bollore

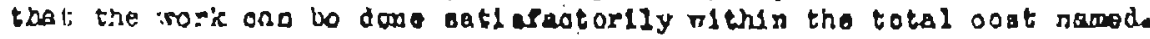

I havo not inoluded any Gabs plunting in tha ostlate bo-

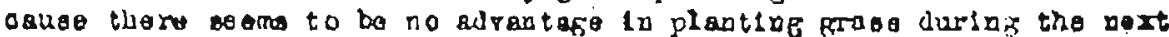
two or threo monthi.

Beforring to your ouggesti on that ooptald areas be covared

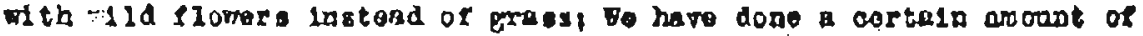
exper lountlag aloag that ll be bat have novor ovolvod anythlog rory sets a frotory or interesting. 'Phe nativo flora nppora to bo poorly edented to when usos, and the ohersator of malntonance noeded to pre-

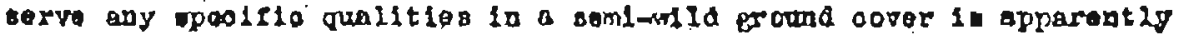
boyoud tho compahension of the alase of labor wo havo aval lable. $1 \%$

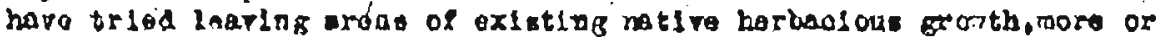

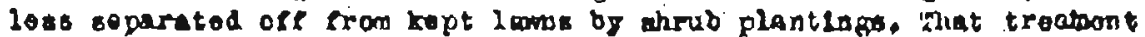
cannot be ald to be thoroughly oetsufectary olther there to a topdopos to rubetltut. law nooner or inter, the eloor elowarlog planto

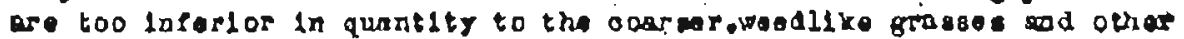
platofor too undopedablo in poourronoe, or do not bloom in the rinter. -o that tho effoob 10 too apt to bo abobynose. I houla bo glad to

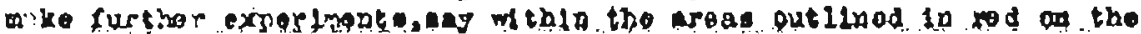
print of plan 502, but I oxould expeat that the inttalamat of a worth-

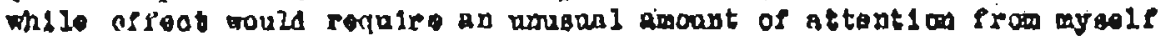
and ry asdating-in othor worde I akould oxpoot that suah a treatront would bo oonsiderably moro oostly than a laim trontment. $\therefore$;

Inasmah as we propse to defor the lawn planolng t111 lato winter

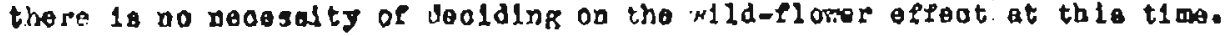
all wo nesd to know so onhothar ap not goa sare to have us go ahead on the rork as ostloatod abowe.

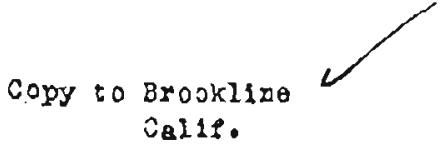

Iocara rerg traly.

(51000Q) T.L.Ph1111po 
ULMSTEL RROTMFH

Rest ve?

MAY I2 904 QH 30

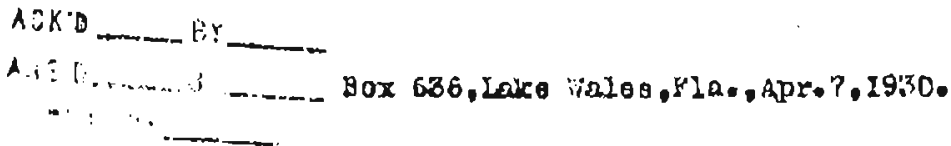

Lis. C. S. Stuak.

gethlohem, Jos.

war ix. Brok,

I have gour lateur of Apr.28 in regare to the

one-ija fountala of gantiggo.

It is bard to form an oplas on of the af feot of the

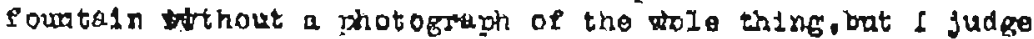
fram what ye.3errago says thes it mitht be out of soale for yone plave. The pool thlone might wo us, though the plen as 14 stands sufregts no obrious poelt1ar ror 1 t, but getting suoh heary stonog trennsported here and gettlag them up prould rrobabis involvo i pro hegh oost for a klnd of effeot that oould be obtained at : :uon lecs exrionge in scowe other may.

I havo had the aciltional jlunting of the lower part of tho lit staked out but hape not yot authorl zod the vork to

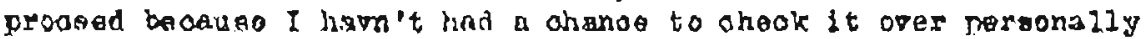
on in. promod.

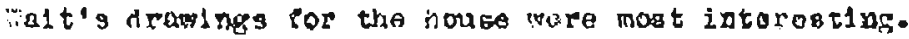
jongerstulat 1 ong.

I suly reosivad your lote or of kpr.IIth arsil will tako :are of tha tinajonos when they arritre.

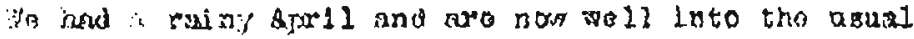

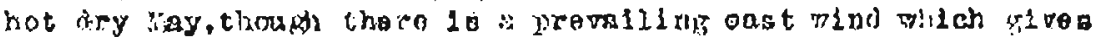

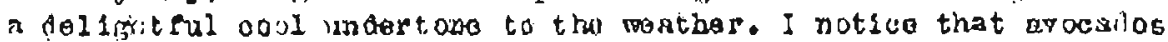

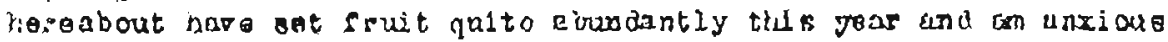
to trg out the intiolo ilat on your rianos.

\section{Qincesoly rous:}

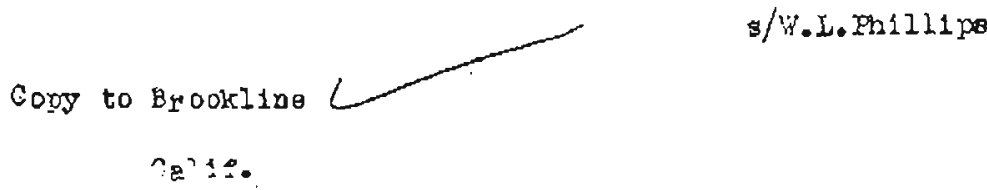


ist.ien. Stzok,

3othloher, Pa.

Dorr in = juak,

I bave jour lettor tho I2th with the copy of

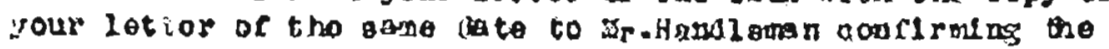
accoptano of flve larso canel11ag. There 18 always a plane for those flas plaste asd though I hare not anlocted looatlano far

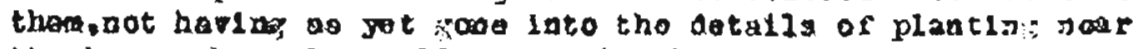

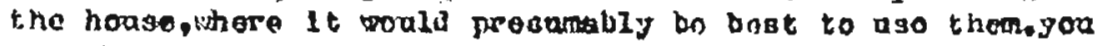

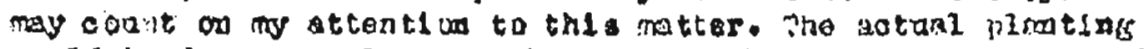
roald bo dono roey late in the joir , not before soopmber oertalnIy*.

'Mo pland for plantlne tho 2 war dxat of the lot

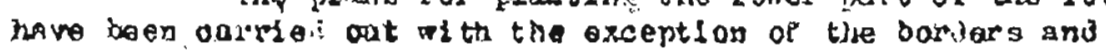

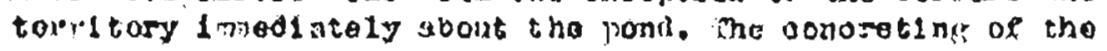

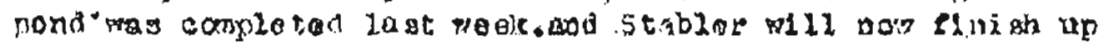

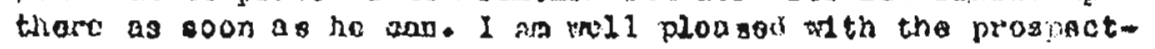

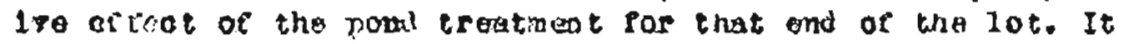
acens to ve just what was peerled to make no interenting lasde

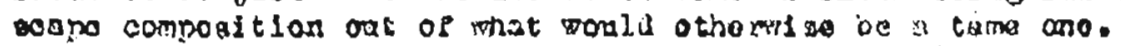

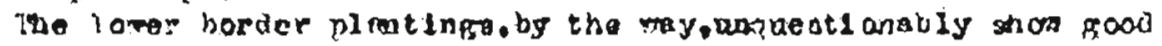

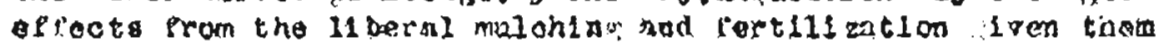

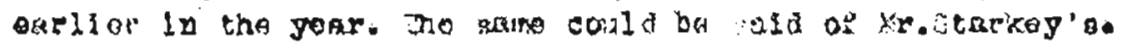

Prompresa $n$ gradtat around the houw has oeed delaym

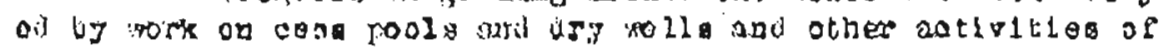
tho houso cobtrelor. yat that is notning to be oonoarnos tabat.

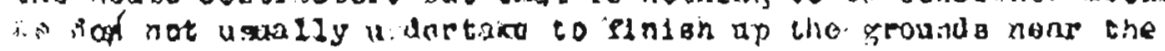

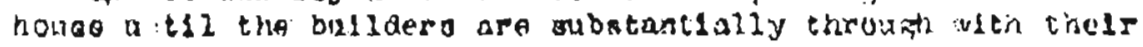

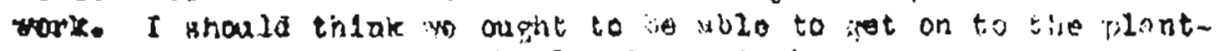
inf of the arper pirt of the lot in joptemhar.

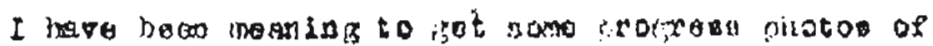

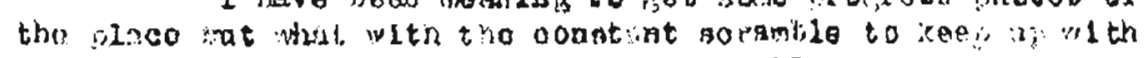

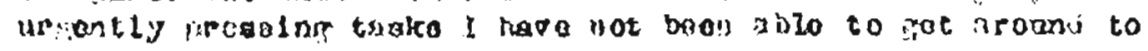

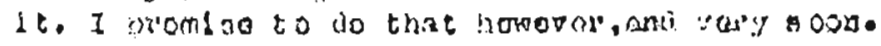




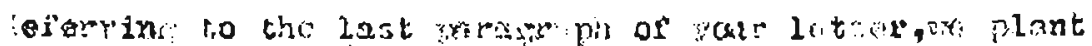

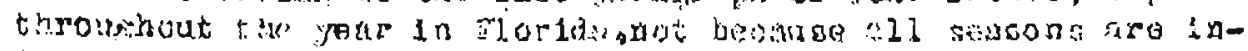

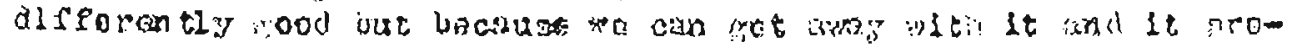

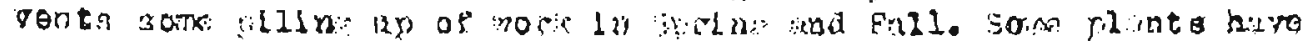

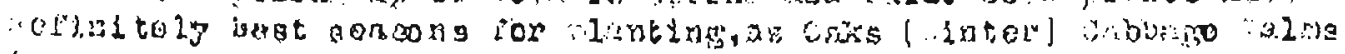

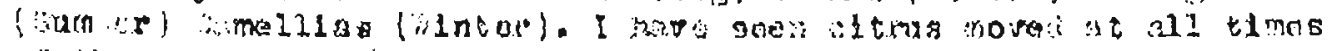

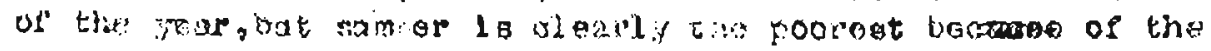

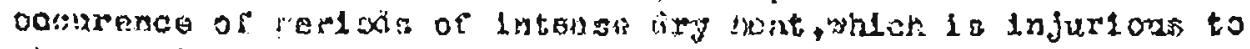

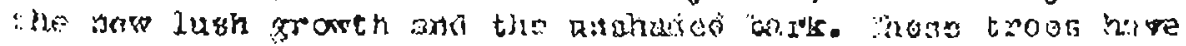

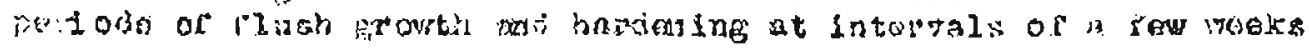

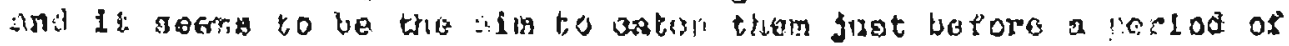

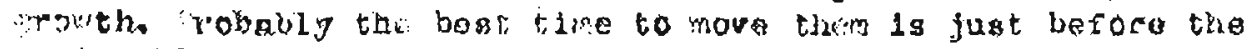

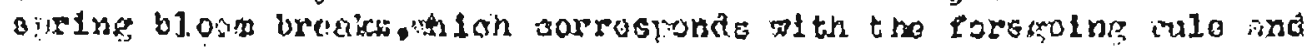

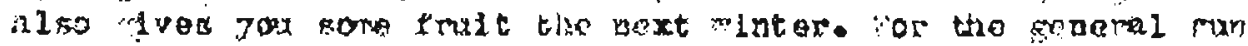

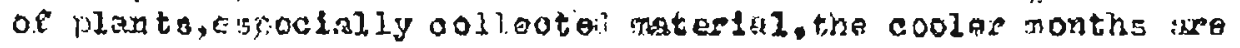

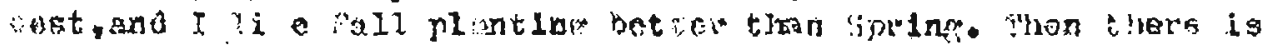

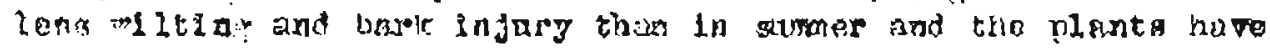

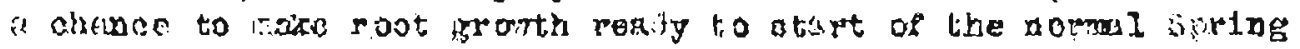

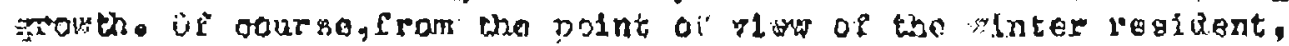

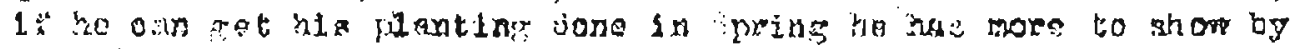

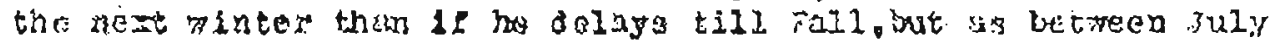

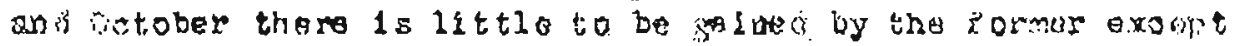
the the rove la gotten out of the reys.

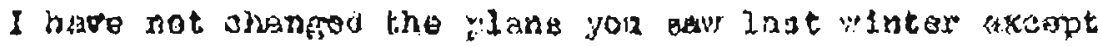

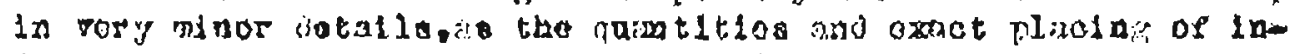

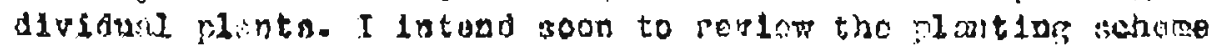

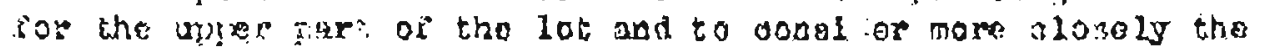

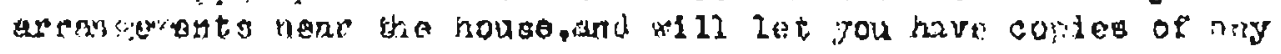
now ningo.

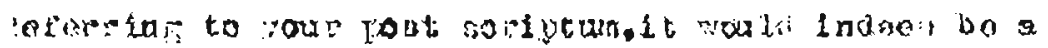

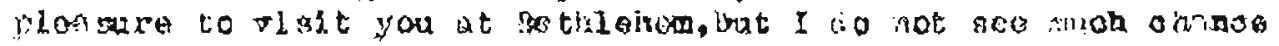

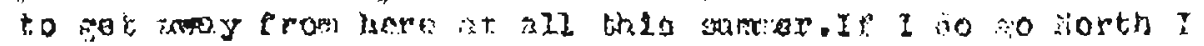

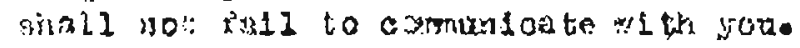

itth Kindent coseras.

incos. 28 gones.

$$
\text { 8) } \because \text {. Dh11I1po }
$$

oppys to Brooking

Cal1 f. 


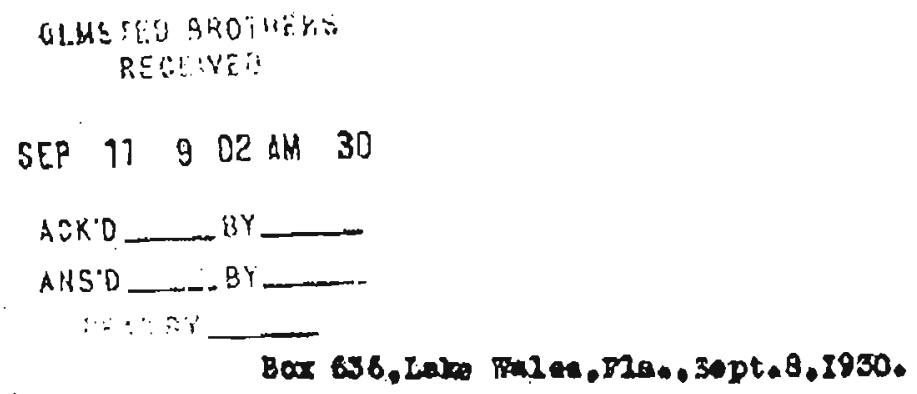

\$r.0. A. Bater.

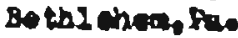

Dow Lr. Bank

rour lotter of tho gal was daly roool red. I sa gad

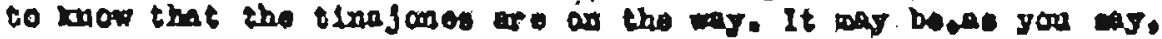

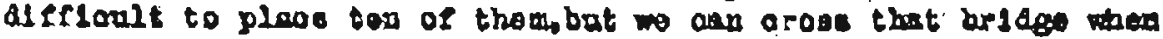
Wo one to $1 t$.

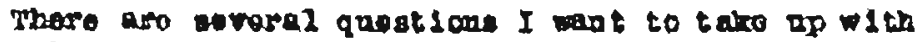

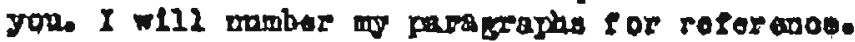

I. I bupt bood stodging hapd of late on tho troatemet of

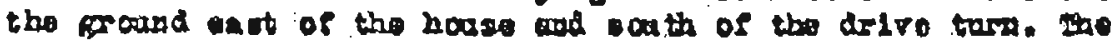

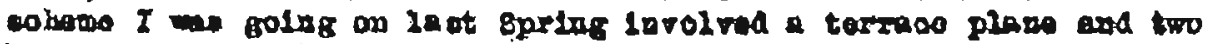

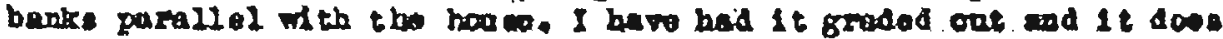

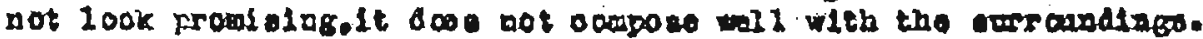
One toels the noed or a lareor Flat aren at tho hoose loor lovel. wdo onough to belog botb the oonter hall and the 11Flog $500 m$ porah

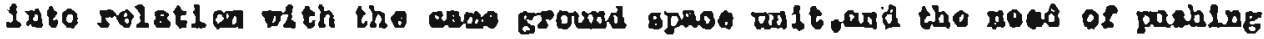

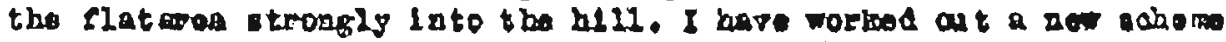

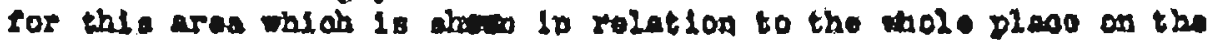

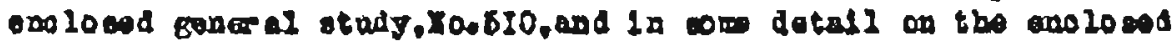

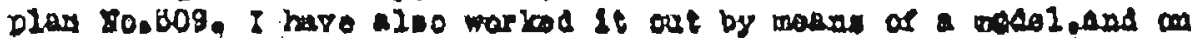
tho wodal it sertelaly l colus rerg good I rogrot that the photos

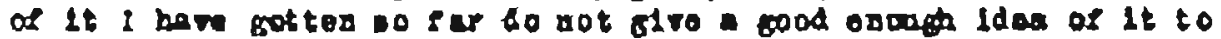

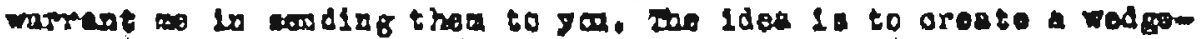

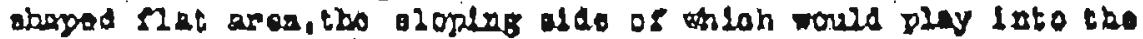

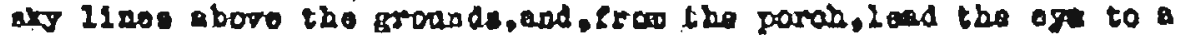

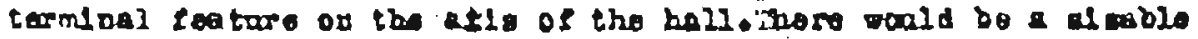

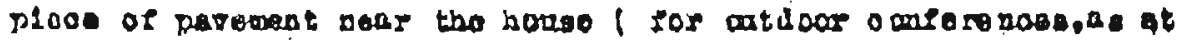

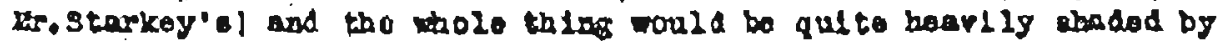

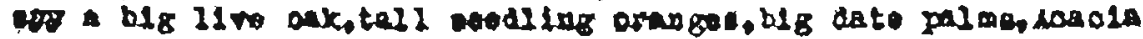

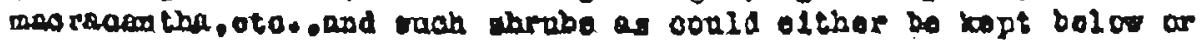

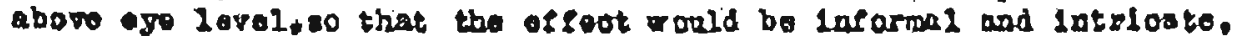

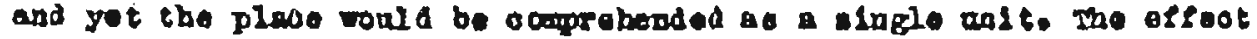
of thrusting lato the h1llefde would bo gooentanted by a grotto at

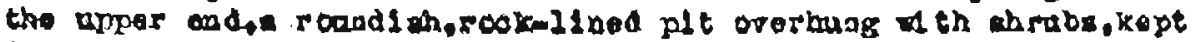

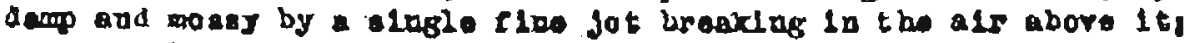
tharo could be a pool, and a "eprlag" ohlah ocald be operated od $0000 \mathrm{sic0s}$. 
2. I am arominet at a lose to presont thlo sobiona to you

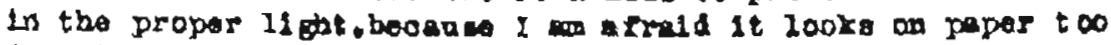

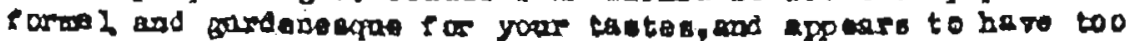

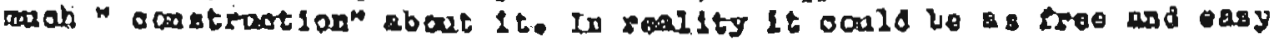

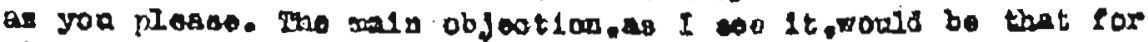
aboat throe goura it would look protty blank and bare. Thet tomorary

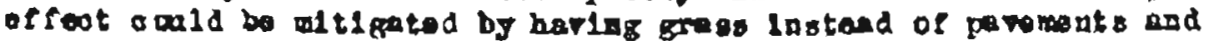
gravel walks at tho start ood ouly patting thom in aftor salfis

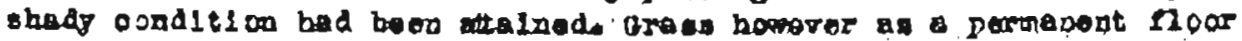
would be quite laosalstent ath that klad of dealgo.

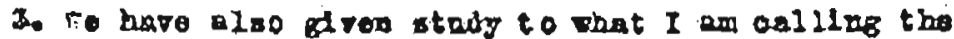

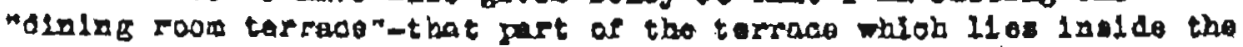

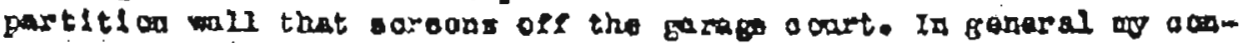

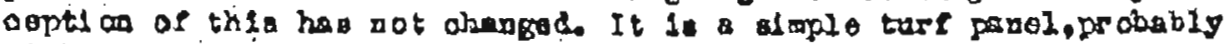

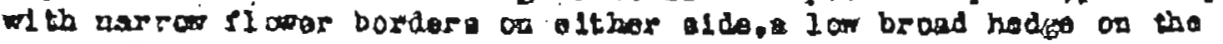
southerly olde, and an intorestlng terainal at the outer and. the

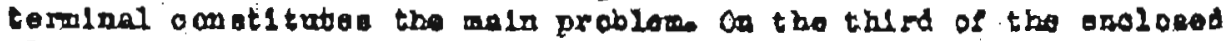

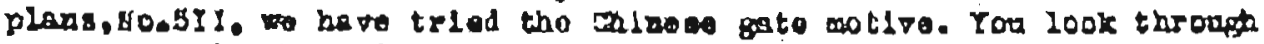

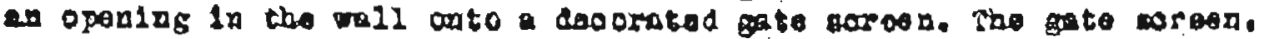

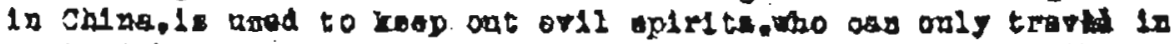

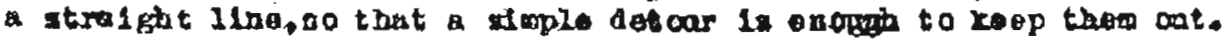

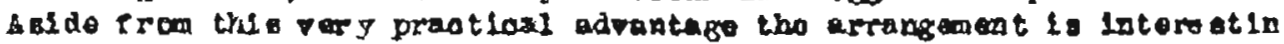

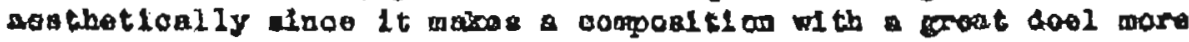
roLler ase play of 11 ght and ahade than woald be poas ble with a simple panel on the wall. The lecoration of the fato sareor ovald be

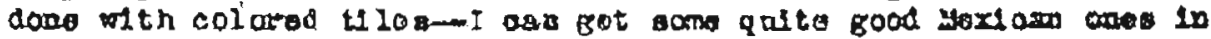

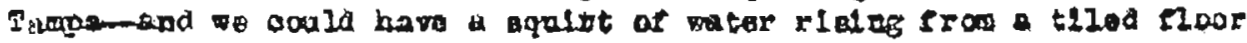

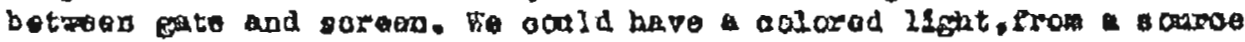
beind the zall,direoted on tbe jotiand asotber of different oolor

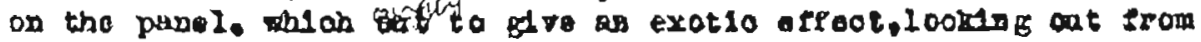
the alnleg, rocon in the orendaB.

4. Anothar thlug I have thoupht of for che torminal fortare

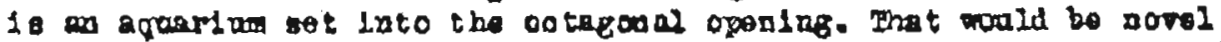
and docorstivo by dayld tot, bat ospoolally o after dark, for wa da

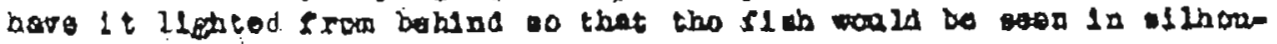

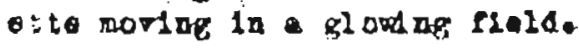

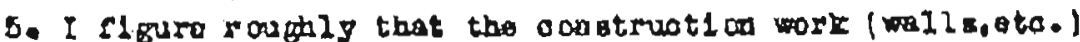

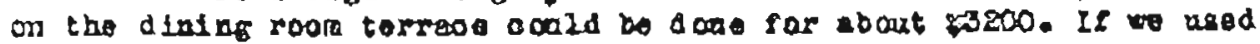

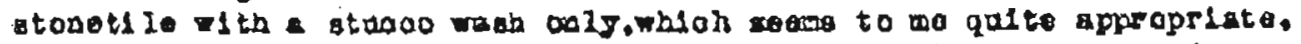

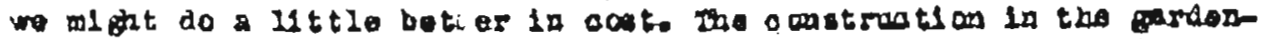

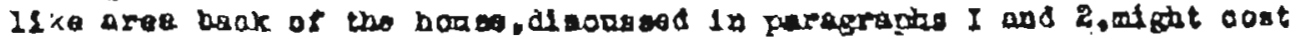
aroand $\$ 6000$. Thl bring an to the questl on of how wo atand on oat1mates in ganoral. Os Oct.I.1939 I gave you a total ostlonto ancanting. to \$32.785.00-I an exolosing a oops of this to savo you tho troublo

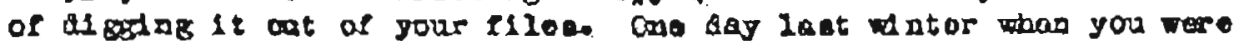

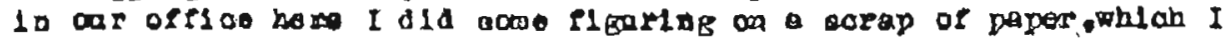

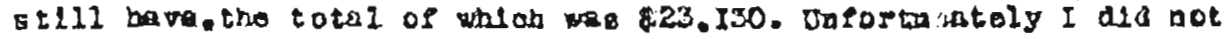
noto it the 1 tems wore, but 1 t la protty clear that I as a not in-

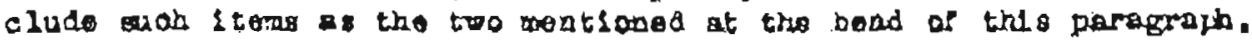

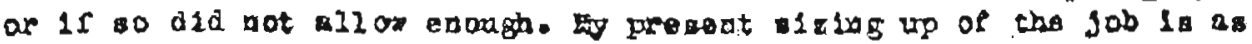
10110018 


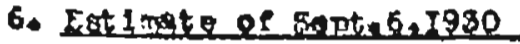

Gralng, rough

Orading, Plin

Isrteat 100

Driro

$-I 640$ ag Jda, \$I.26

Pand

Dinlne room terracom

Last gerdor

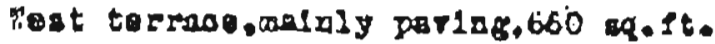

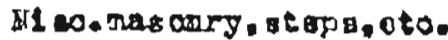

$\$ 2000.00$

500.00

8000.00

2050.00

$I 800 \cdot 00$

$\$ 800,00$

6000.00

35.00

500.00

\section{Total E19380.00}

The total of the plant Ing ostimtes $512,163.00,00$ 2ain eati-

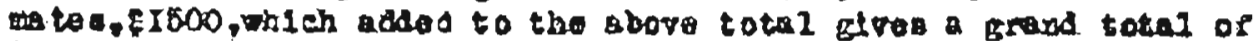

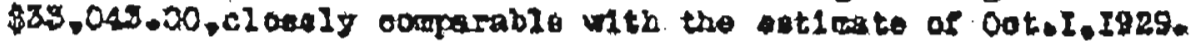

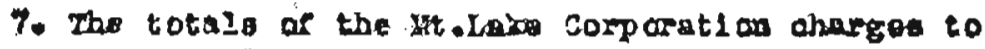
July I5, 5930 wore as eallows:

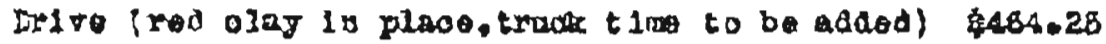

Grading 841.56

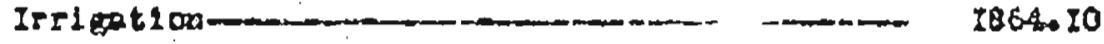

Pond.

1688.57

Plont1ng 4362,90

Totel \$8916.46

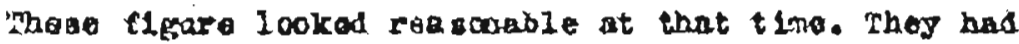

BII the alay on tho driven lergo part of tho rough grading wa doar,

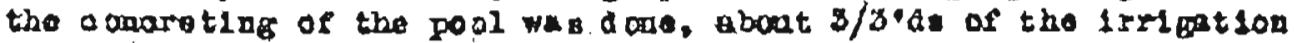
was in, and the planting of the lowe part of the roond was largaly

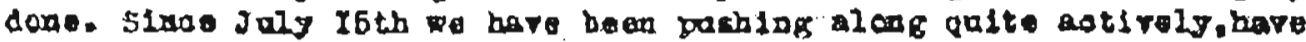

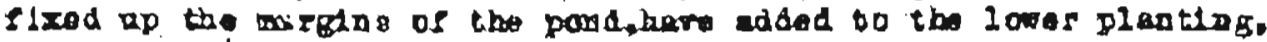

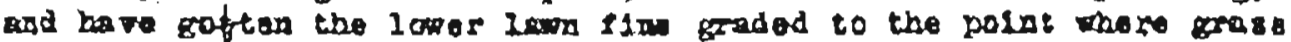

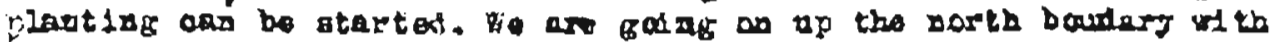
tho bordes julantinge a oonsidareble anount therefore ba beat apant

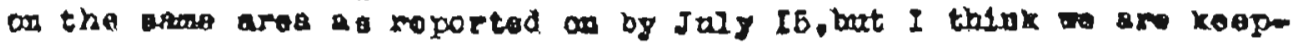

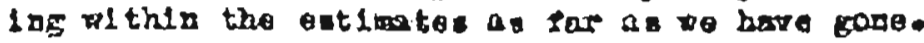


8i If the totel of tho ostinatei as given la paragreph 6 Is more than you want to rpord wo call probabig have to soek a Leà oostly solution for the area just of of the house and south

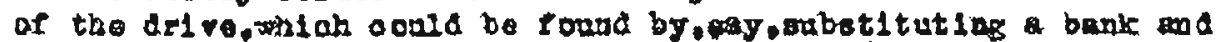

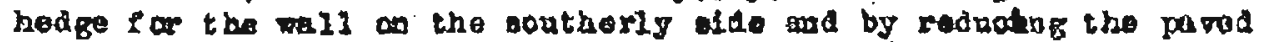

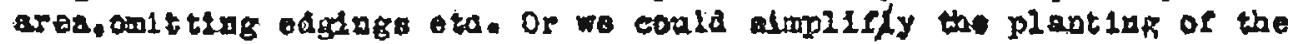

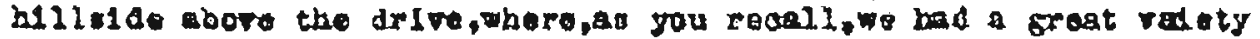

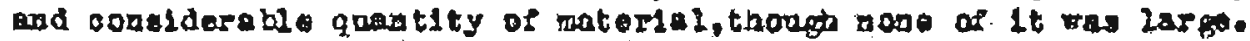

9. Rotice that on the 20it hand aldo of the lower lawp

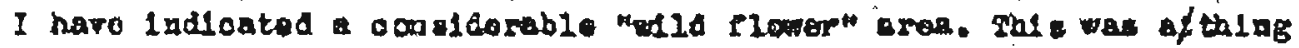
whloh you orfedially proposed, and I mode no adrerse roport on $1 \mathrm{t}$. Sinos than wo have found two or three plant whloh aro falriy antio-

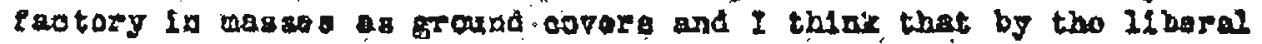
uos of thom ro coula do the triax. I an sure that tho goseral opor.

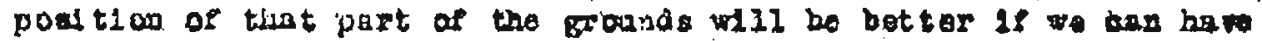

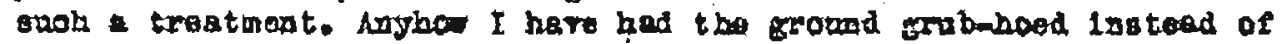

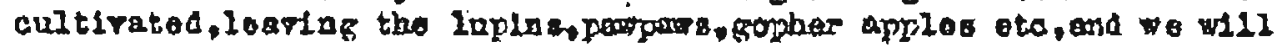
try It out.

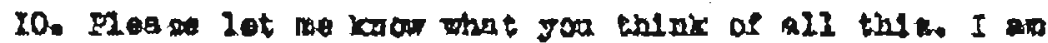

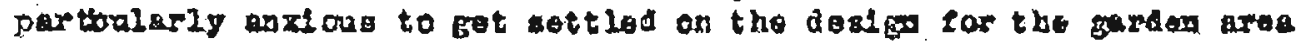

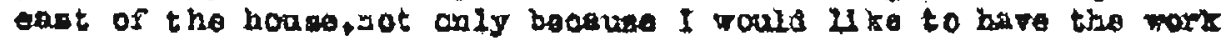

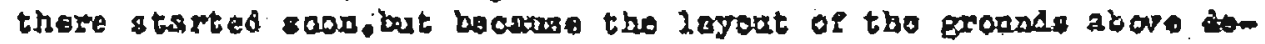

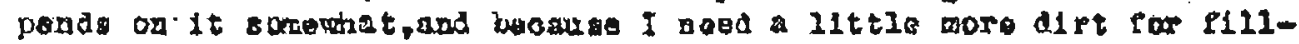

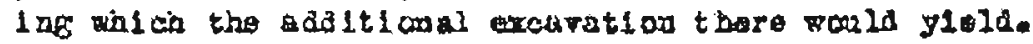

II. In the orat that jou approve of the destaps, ab-

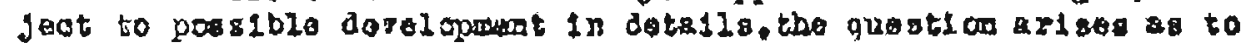

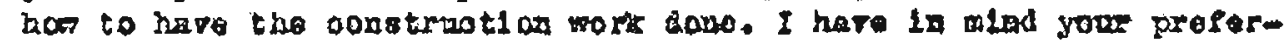

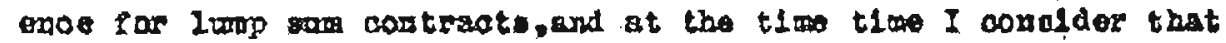

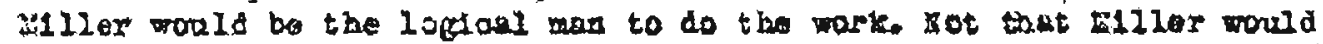

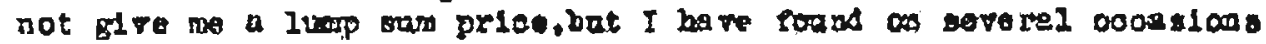

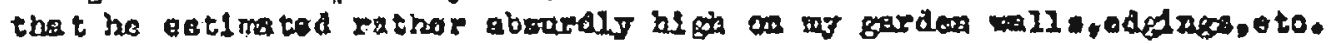

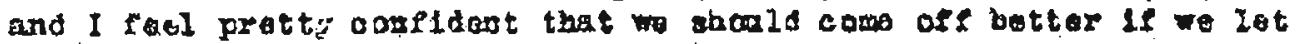

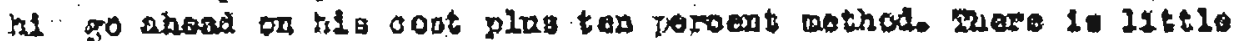

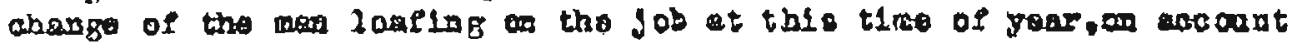

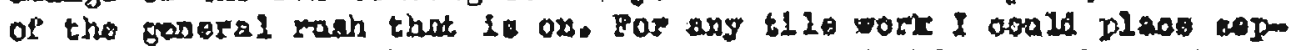

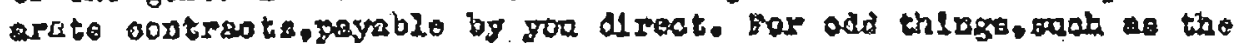

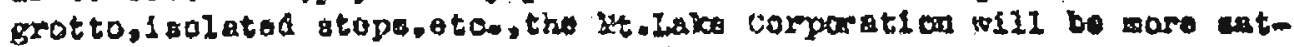
1 atautory.

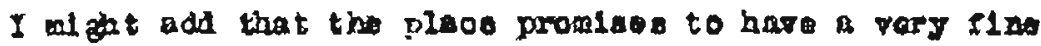

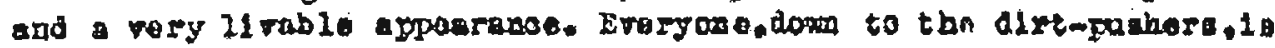
anthuslastic about it.

$$
\text { Toare pery traly. }
$$

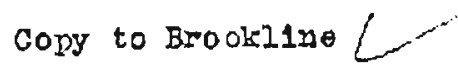

g/ $\because .1 . P_{\mathrm{h}} 1111 \mathrm{pg}$

Calif. 


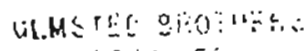

$$
\begin{aligned}
& \text { بs: : : } \\
& \text { SEP } 15 \text { 9 19 14: } 30
\end{aligned}
$$

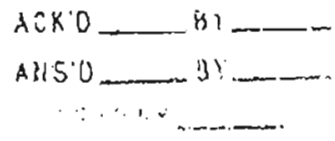

$$
\begin{aligned}
& \text { Lake wa } 208,8 j a, \text {, Sept.9.1930. }
\end{aligned}
$$

in.C.A.Buak, Be thlohom, Pe.

Dear sto.Buok. In my letter guterday I meant to yal so tho quastl on a to mobher or pot thero la any likalihood of jour anting a tom lo colnt. If tharo is auch a likelinood I thibk wo had betior regerve a paos car it somowhere, and the boet plaso,1t seome to ge, woald be in the northoast corner of the lot as shoms on the enologad eketah. It would bo out of tho. there-thet ia to say it rould not gpoll

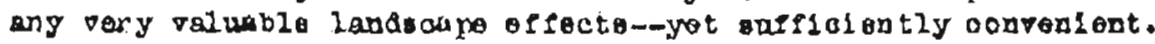
und if oould be cotton in without outtingeng plnos.

ibla quetion affeot our plantlog rark, wo I shelI bo glad to have your oplnion as aon as oonveniemt.

Mare were one or two polnt about the atimate a whloh I should have explas aod more hilg. I om plapalog to use en aephalt10 magadom treatmont on the arf curfuce. Tis have not had experlonoe hore euerialent to enalide uo

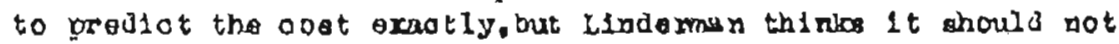

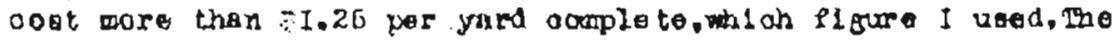
curblag.118tod in my eatloute of Oet.I. I929, would not be nooosary.

You w/2l perhape wondor why I allamad oo much for grading. 25000 . When I asid that on July Is tho rouph gradiog wa larpoly done. and get they has oharged only $\$ 541.00$. That 18 be-

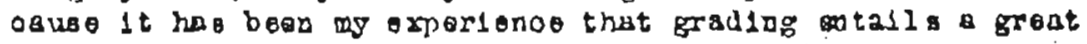
deal of fuselng around after the appoximatoly oorsot maint of

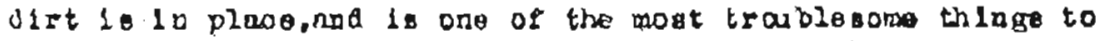
got properly done horo. I tberefore made en ampla allomance for 1t.

The Irrigation work vill probably run quito a bit wader 3000 . bot I thousht it sater to rotaln that Flesare.

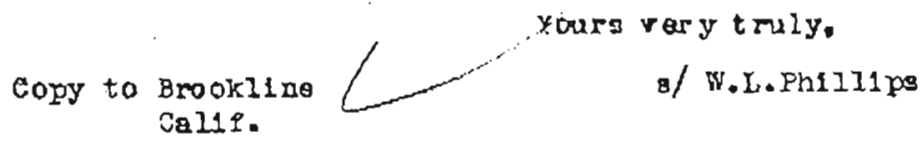




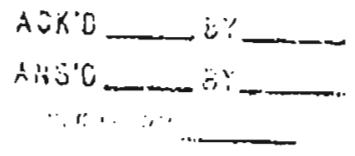

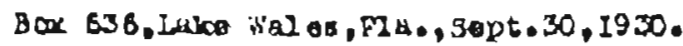

Bre. O. A. Buair.

Bathlohem, Pra.

Door sur. Buek.

Your adreree docision on the oorerod walin and

arbor threw wo somorhat ant of goar an my gardon plano. I bas

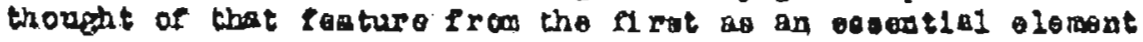
iv the anoeption of the house plan and layout and I did not Irmodetely owe how to do wh thout 1 t.

Bowoveraftar ocos ldorable atudy I have oome to tho conolusion that a cood looking open arrangement can be modo. That canolunson has rosultod in a roriolon of the gardos plan as woll

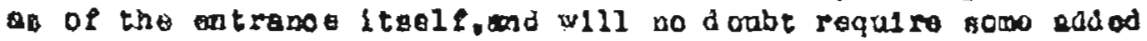

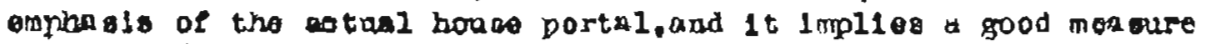
of that delay in time sor tho growth of grean soreens lnotead of

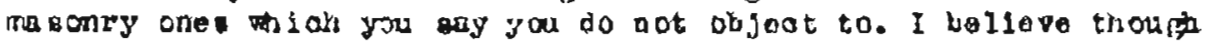

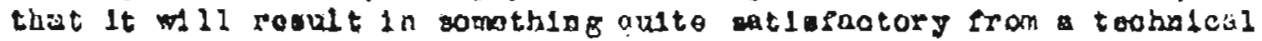
Fiempolat, and more in line with your tagtas.

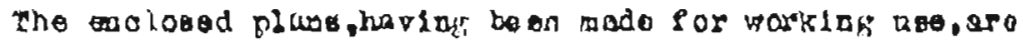
not too good for explonstary purposon, but takon in oornoction with

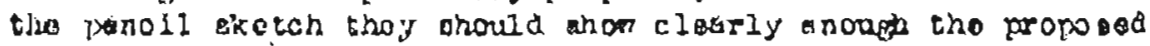

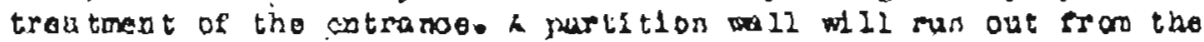
house at about the holght of \& 10 n yaraset wall nxtendiog around

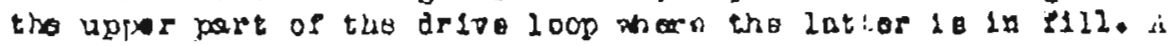
fllegt of atope clanked by poets with rlaor pote on top wlll lead

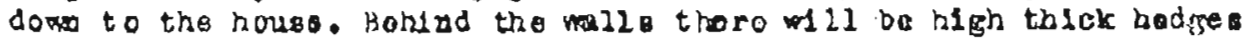

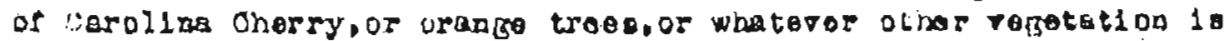

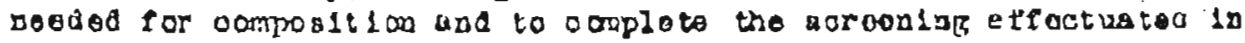
part only by the rallo. Tho walla tromselvas will aroutally bo

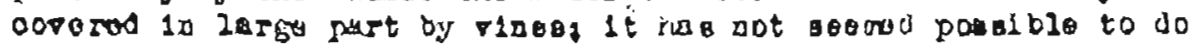

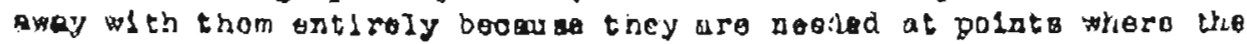

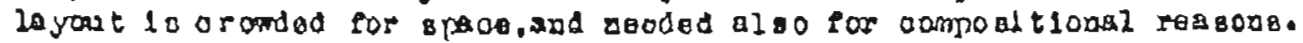

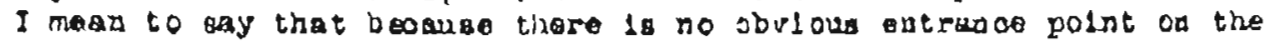
house it is nooouary to orosta one oatside of lt: and to do that with almple forme wo shordd at leagt aso arterial of tho sane aptearanos the hous 128 . 


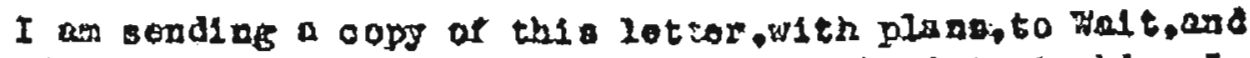

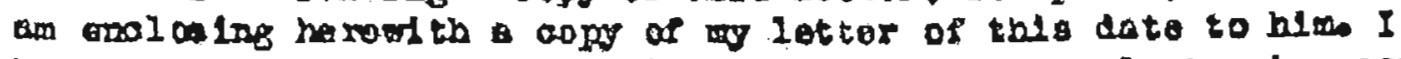

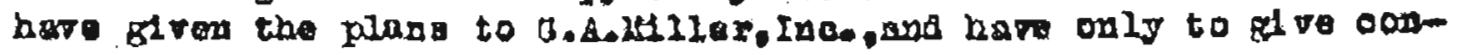
Irzatory ordarg to bave the work ataredo

\section{sinoerely gours.}

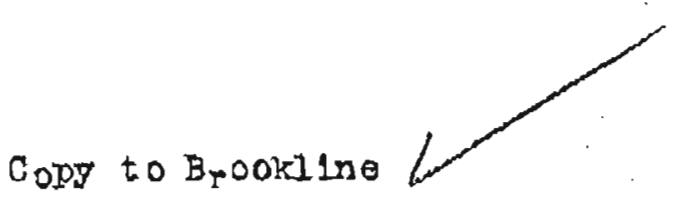

a) W.I.Pbll11pg

Parsozs, wait and loodedll 


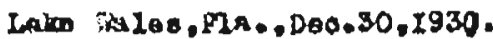

Hr. C. A, Buak.

Bethlohom, Pa.

Dens Le Bual.

Lirstablar has geot too coplog of your lot tor a to

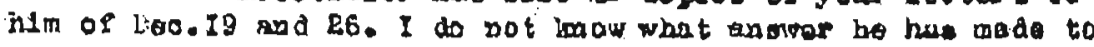
these lettera but a asuro he worizd liko to have wo ooment on tho iroes gor ment $1 \mathrm{cos}$.

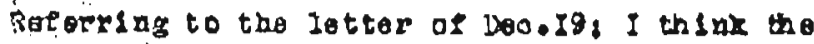

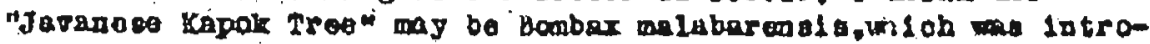

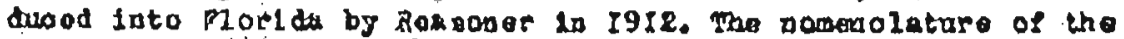

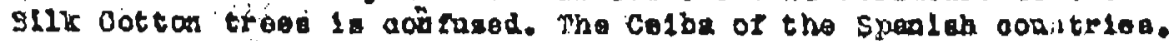
raol llar to you no doubt, ha bewa doelgated as Bonbar oslba and

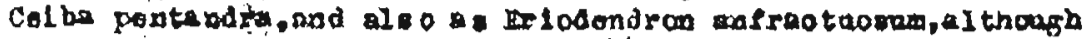

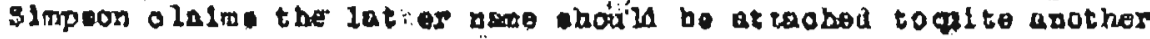

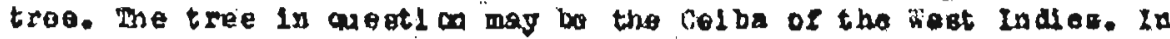

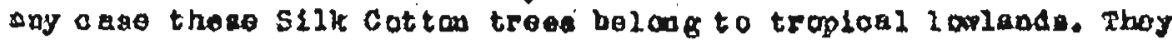

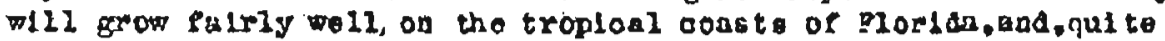
oonoefrably,10 farorded apots on the Plaeliat ionlabala. I an quito care they would begar umout to ery.thlag here.

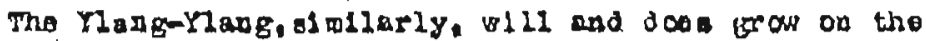
tropleal oasets of the stato. I pould not wate time on it hare.

rous lettar of the 26th mentione soods reaolrod by you

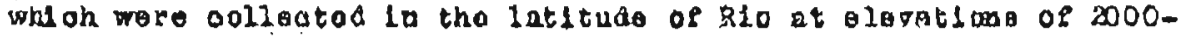

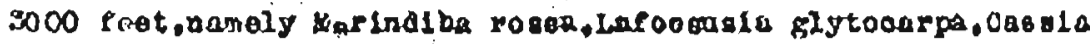

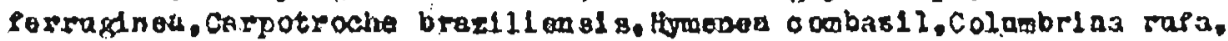

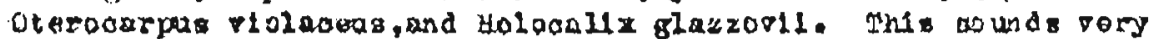
Intoroating. I havo theorg chat vearly all of the tropioal apecieg

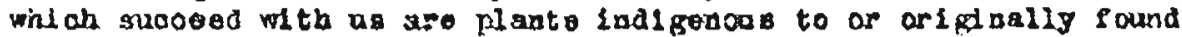
In troploal hlphlands, woh, for Inatanoo. Sapota). the Guatemaing atd Hexlost swooadoar and Rhodonyetur tomon to was. In the hlgilande,plants though arbjooted to a st.iotlg tropjoul roeimen of audight would omobanter mot- tomporaturea wob nore

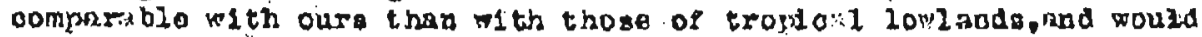

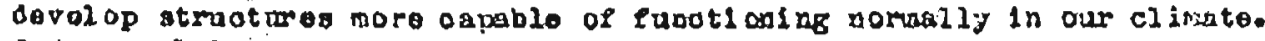
I do aot vellove tho plat latrodaders ia slosida orer pola ebcagh attents on to wioh a theory-1t' they di a I ne ver hausó of It. Int

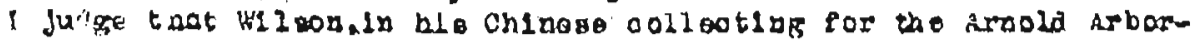

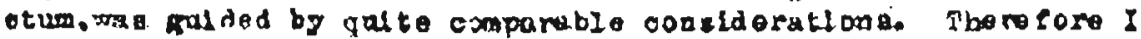


look forwed with maboh laterost to the propagatl an of the seoda

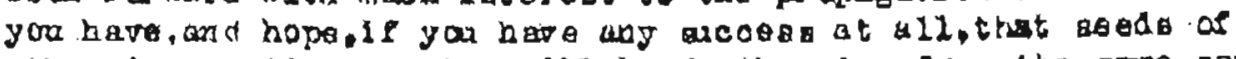

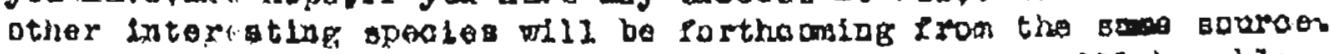

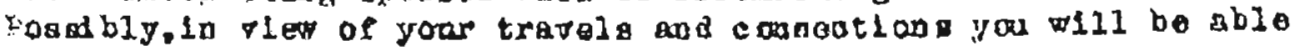
to got colleatione from other hish tropial regions.

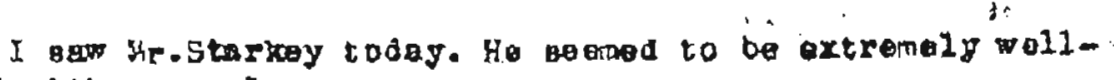

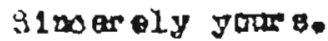

n $8 /$ W.I.Fulizips

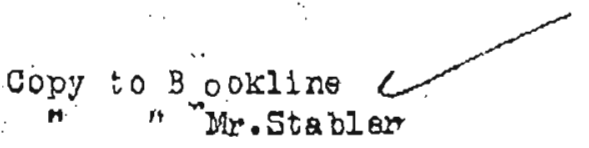




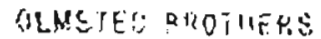

RE: : : : :

WAR $30 \quad 9 \quad 04$ AN 31

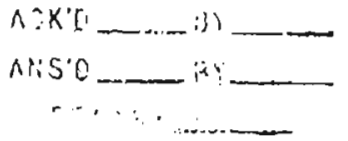

Lin $26, I 98 I$.

20. C. L. Bopot.

o/o Betblabem Stoel Compary.

Beth Labaen, En.

Den teragic.

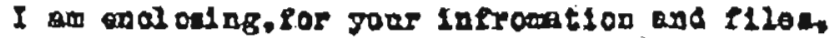

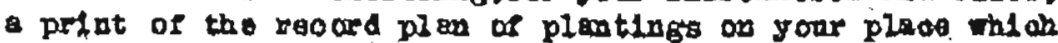
wo mde up reoently. This 18 ouppasod to bo oorreat ase oomplete.

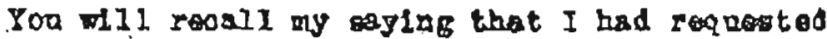

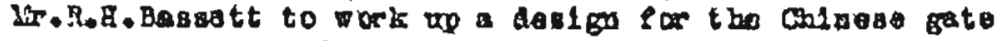

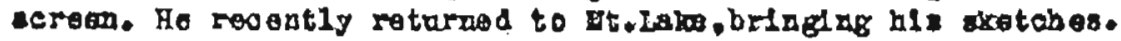
Thase seers to me to repreaent the riad of thisg needed. I baro esired hlo to writo and explaln the ldes to you d brat.

In talking with in. Bas aett I d achased tho poseiblilty

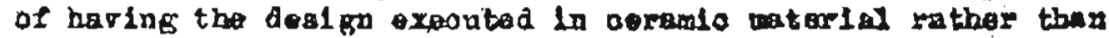
In 001 ored plastor as oomoelved. That would afford a mob wore brillant decoratl on and roald anque et lonably be 1deat ,bat difelonIt and aostiy to get dane in the julted stbtes. It co happora that Kr. Baseatt and I are both plamalag to go to Spalo tblB

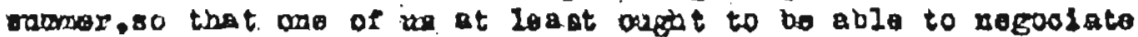

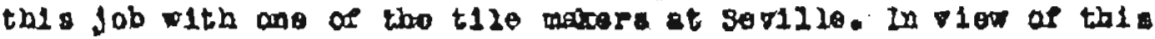

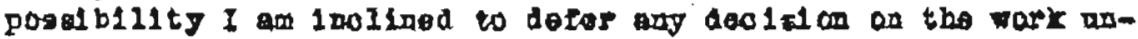
t11 wo hall hare had an opportunity to cos at ocala be obtalned

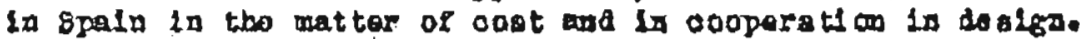

SLAore $2 y$ gares.

$$
\text { s) T.L. Th1121 po }
$$

oopy to xis. Bassett 
Up.C.A.Buak,

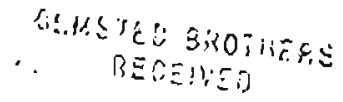
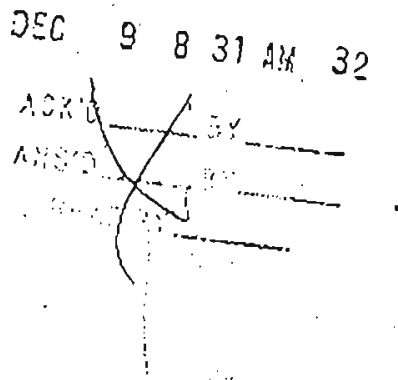

412 Alutrallan Aromen,

Palm Boach, Fla, Doo, 6, 1932 .

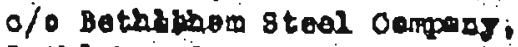

Dothlobom, pa.

Dear me Brok,

I returned to plorlda areand the midal of or gomber

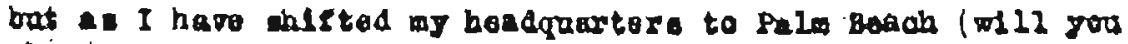

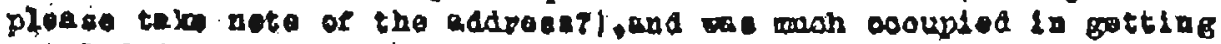

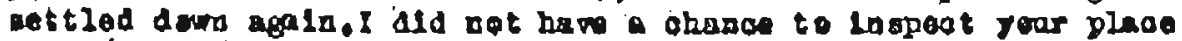

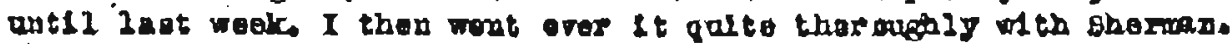

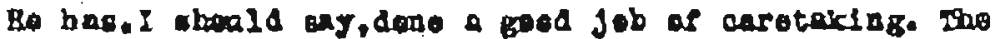

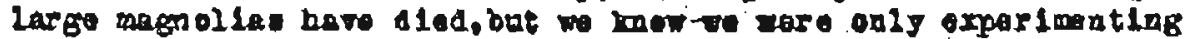

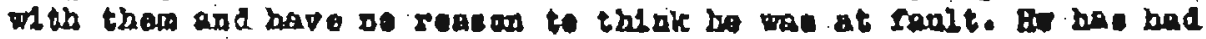

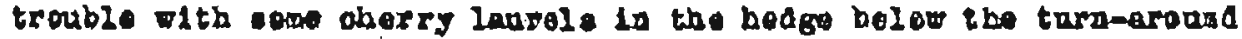

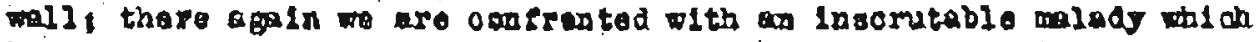

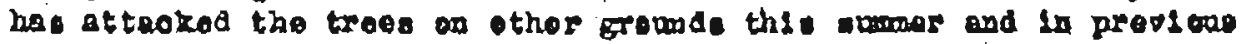

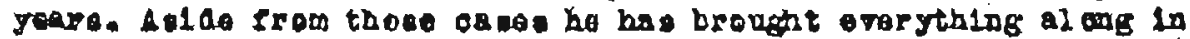
aOrnal or uperior oordits un.

Thothar or not to oxpordand furthor wh largo mapallas deperde on your preforence. I do net thlok thom oacoitial from the

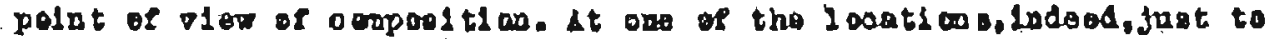

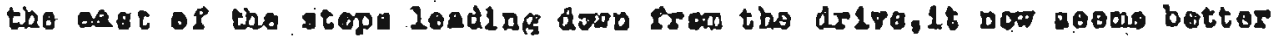

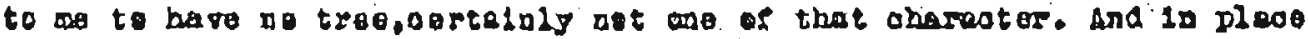

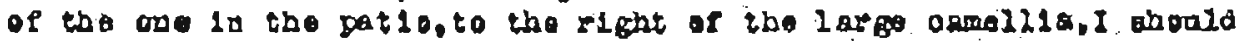

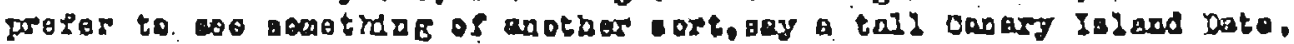

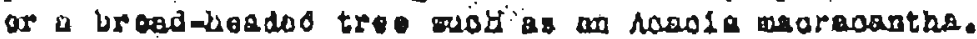

One roo ormedetl on can be mode to appig to the place gen-

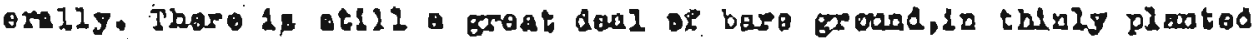

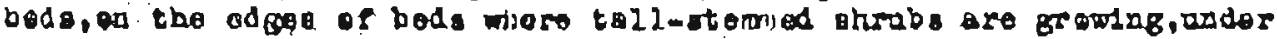

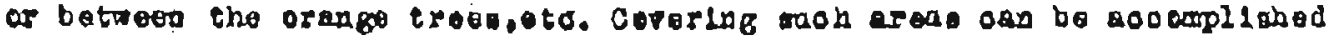

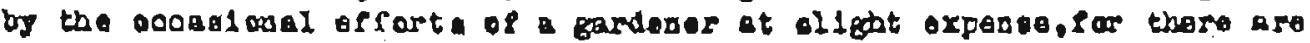

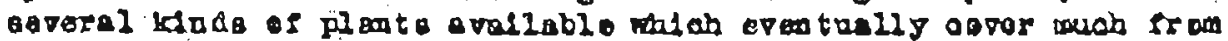

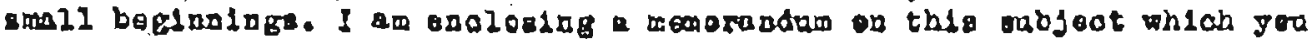

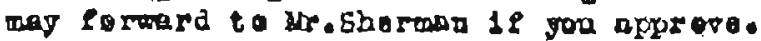




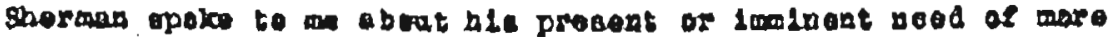

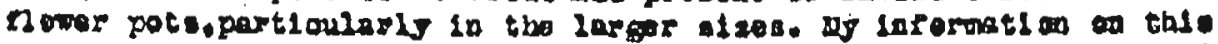

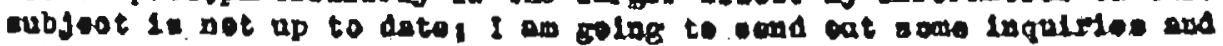

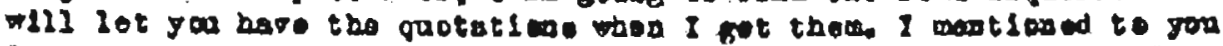

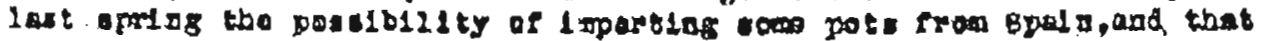

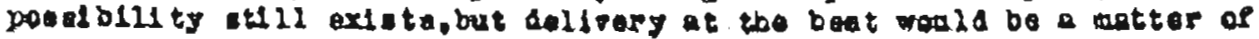
monthe.

Fith eindoet rogards.

Elucorely jours,

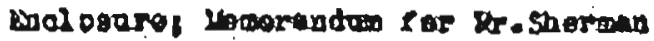

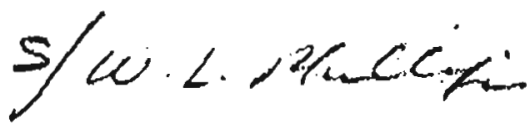

Copg to Brook1200 
D.0.6.1938,

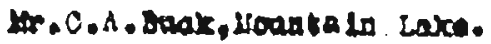

$\cdot$

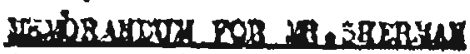

By T.L.Th1111PE,000.6.2932.

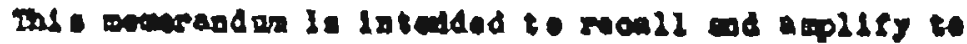

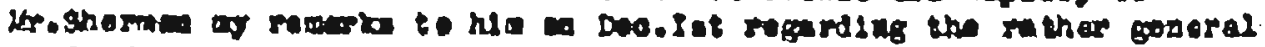

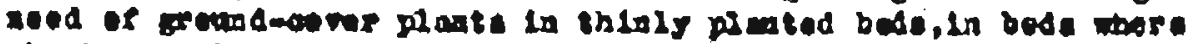

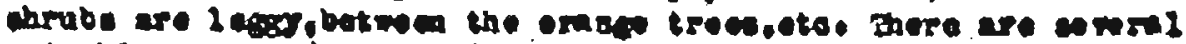

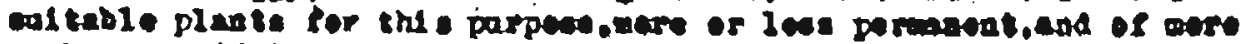

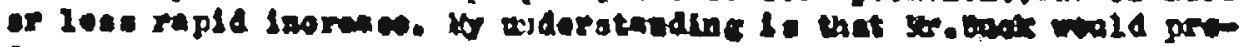

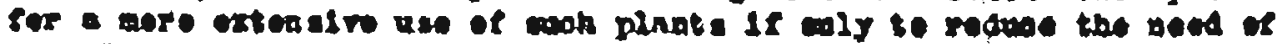

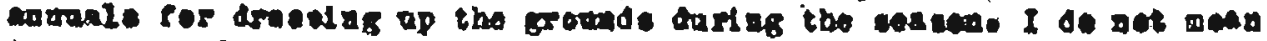

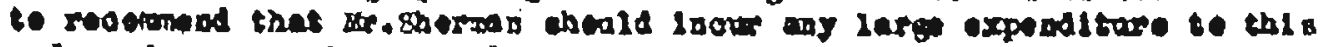

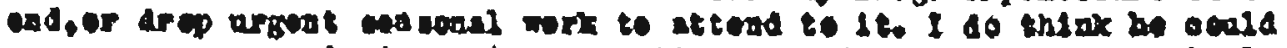

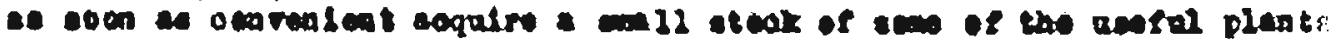

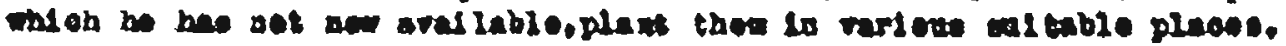

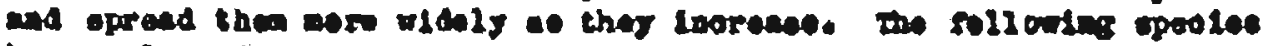
hare ralus of wo port or mothers

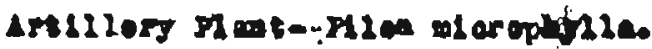

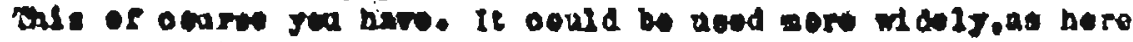

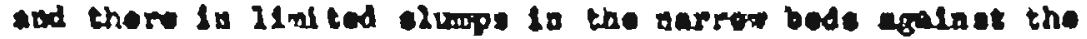
nous malise

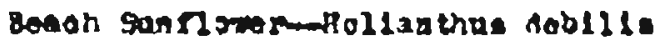

Thl zoa

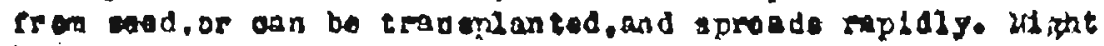

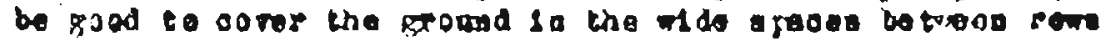
of orango ireas in tho apres papdon.

Croopleg Daler-biodolia trilobata

You bare It abondastiy alrady. Ito naseos are alanst too

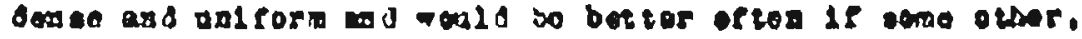

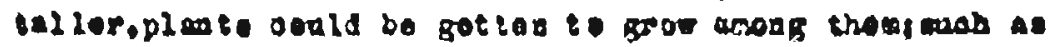
perdetalis, Bryoghyl law, sancerd orta.

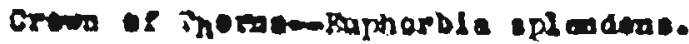

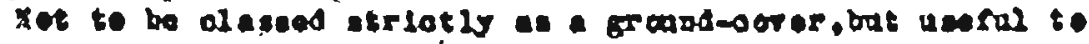

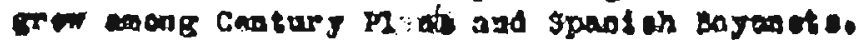


Dohendre

A rers peostrate. Plat-groulng plent. Oen bo gotten frin Ragener.

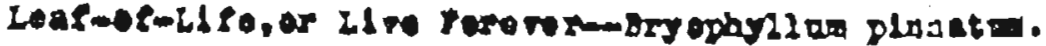

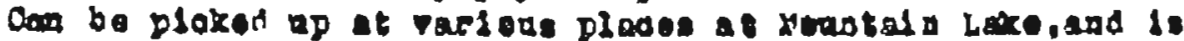

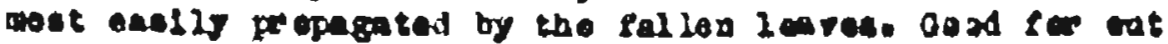

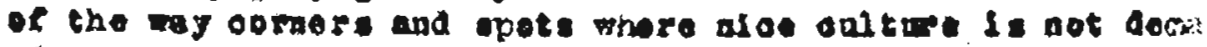
ed.

Japanesa Orese or loasm-zojala Japestoa.

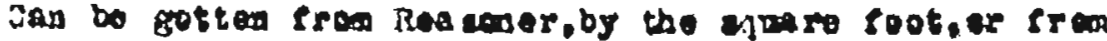

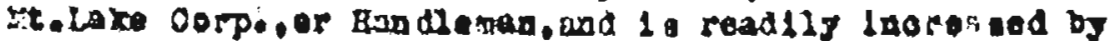

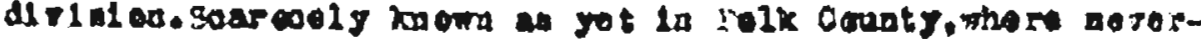

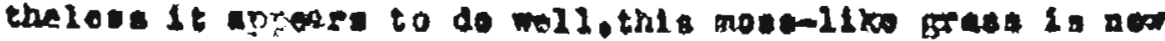

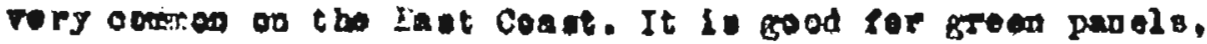

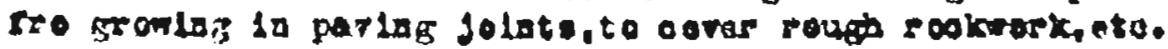

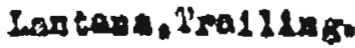

The oolor of this pleat in broad manue is mogrbs to ranj

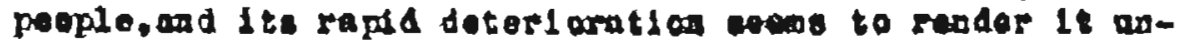

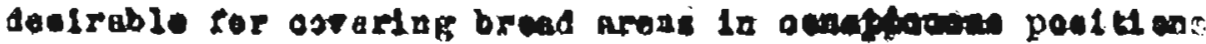
Is can howorer bo rotaloed in enall patches. I advised ar.

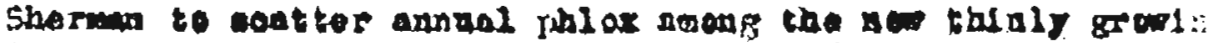

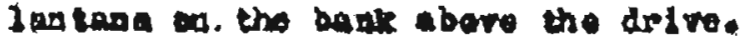

Popererata mo

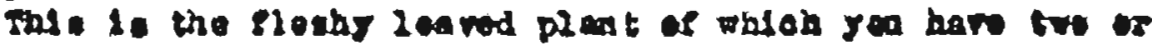

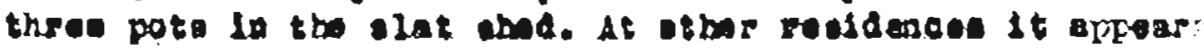

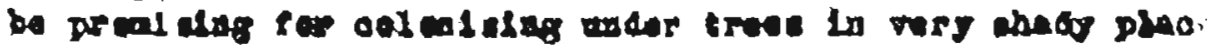

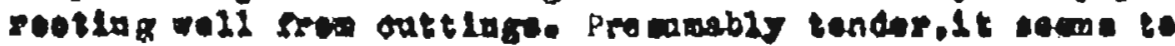

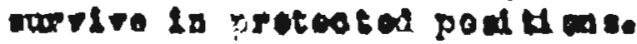

Pardodardertigoa pouch

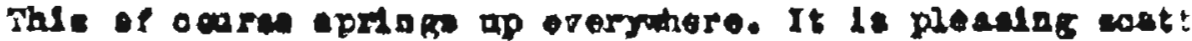
here ad there anag the shrabs,bat as boobut of its tono

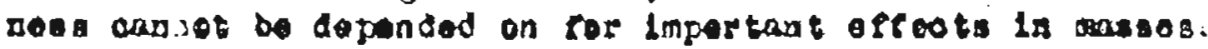

Sensertore

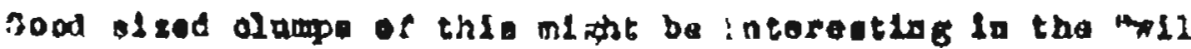

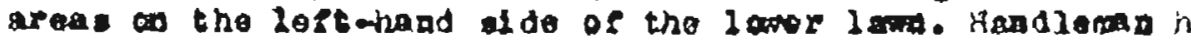

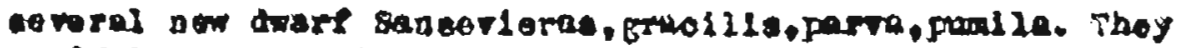

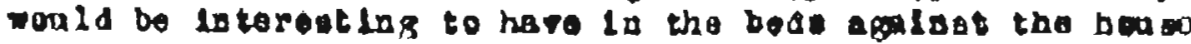

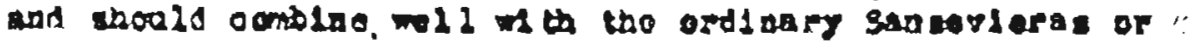

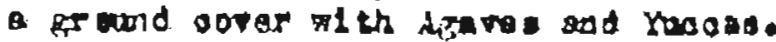

Suakebenta-Ora epegeo Japoason

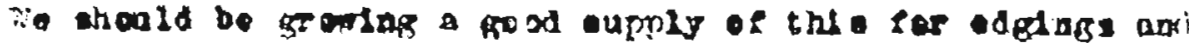
pangl to. 


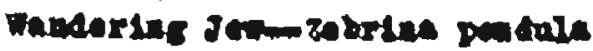

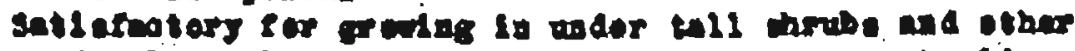

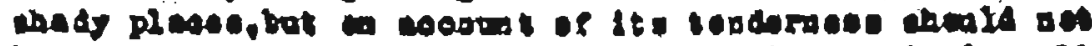

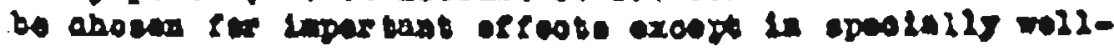
proteosed pleces.

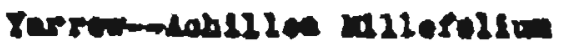

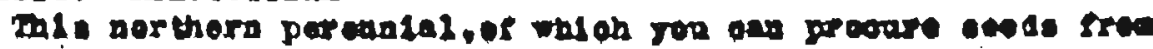

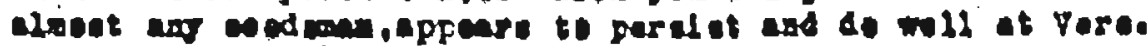
I sheald 21 xa to we is tried of yeartals Inte.

oopy to $3 r 00 k 11$ ine 


\section{APPENDIX B}

Plant List for Phillips' Planting Plan \# 523

\begin{tabular}{|c|c|c|c|}
\hline \# & LATIN NAME & COMMON NAME & QTY \\
\hline 1 & Callitris verrucosa & Cypress pine & 150 \\
\hline 2 & Laurocerasus caroliniana & Carolina cherry & 142 \\
\hline 3 & Grevillea robusta & Silk oak & 26 \\
\hline 4 & Eucalyptus rostrata & Creek gum & 36 \\
\hline 5 & Eucalyptus robusta & Brown gum & 2 \\
\hline 6 & Bauhinia purpurea & Mountain ebony & 22 \\
\hline 7 & Cinnamomum camphora & Camphor tree & 21 \\
\hline 8 & Quercus virginiana & Live oak & 21 \\
\hline 9 & Quercus geminata & Twin-cup oak & 6 \\
\hline 10 & Callistemon lanceolatus & Lemon bottlebrush & 32 \\
\hline 11 & Eriobotrya japonica & Loquat & 21 \\
\hline 12 & Citrus sinensis & Valencia orange & 17 \\
\hline 13 & Citrus sinensis & Pineapple orange & 14 \\
\hline 14 & Citrus grandis & Walters grapefruit & 6 \\
\hline 15 & Citrus grandis & Marsh seedless grapefruit & 1 \\
\hline 16 & Citrus nobilis $x$ grandis & Tangelo & 1 \\
\hline 17 & Citrus nobilis deliciosa & Dancy tangerine & 11 \\
\hline 18 & Citrus sinensis & Seedling orange & 16 \\
\hline 19 & Cocos plumosa & Plumy coconut palm & 25 \\
\hline 20 & Callitris glauca & Cypress pine & 5 \\
\hline 21 & Persea americana $B$ & Fuerte avocado & 3 \\
\hline 22 & Persea americana $A$ & Lula avocado & 3 \\
\hline 23 & Persea americana $A$ & Collinson avocado & 2 \\
\hline 24 & Persea americana $B$ & Winslonson avocado & 6 \\
\hline 25 & Persea americana $B$ & Nimlon avocado & 2 \\
\hline 26 & Buddleia officinalis & Pale butterflybush & 77 \\
\hline 27 & Buddleia asiatica & White butterflybush & 1 \\
\hline 28 & Schinus terebinthifollius & Brazilian pepper & 112 \\
\hline 29 & Duranta plumieri & Golden dewdrop & 76 \\
\hline 30 & Jasminum pubescens & Furry jasmine & 57 \\
\hline 31 & Tecomaria capensis & Cape honeysuckle & 109 \\
\hline 32 & malvaviscus conzatti & Turkscap & 17 \\
\hline 33 & Plumbago capensis & Cape plumbago & 558 \\
\hline 34 & Jasminum humile & Yellow jasmine & 15 \\
\hline 35 & Gelsemium sempervirens & Carolina yessamine & 294 \\
\hline 36 & Daedalacanthus nervosus & Blue sage & 138 \\
\hline 37 & Olea europea & European olive & 7 \\
\hline 38 & Punica granatum nanum & Dwarf pomegranate & 10 \\
\hline 39 & Acacia longifolia & Sidney wattle & 11 \\
\hline 40 & Catha edulis & Arabian khat & 5 \\
\hline
\end{tabular}




\begin{tabular}{|c|c|c|c|}
\hline \# & LATIN NAME & COMMON NAME & QTY \\
\hline 41 & Gerbera jamesoni & Transvaal daisy & 39 \\
\hline 42 & Melaleuca leucadendron & Cajeput tree & 28 \\
\hline 43 & Phoenix reclinata & Date palm, senegal & 16 \\
\hline 44 & Citrus mitis & Calamondin & 4 \\
\hline 45 & Fortunella japonica & Kumquat & 3 \\
\hline 46 & Citrus limonia & Villa franca lemon & 2 \\
\hline 47 & Citrus aurantifolia & Tahiti lime & 3 \\
\hline 48 & Citrus aurantifolia $x$ japonica & Euster limequat & 1 \\
\hline 49 & Jasminum floridum & Yellow jasmine & 19 \\
\hline 50 & Thryallis braziliensis & Thryallis & 4 \\
\hline 51 & Russellia junicea & Coralblow & 111 \\
\hline 52 & Ficus altissima & Lofty fig & 2 \\
\hline 53 & Hibiscus euterpe & Single salmon hibiscus & 14 \\
\hline 54 & Hibiscus rosa-sinensis & Single scarlet hibiscus & 37 \\
\hline 55 & Ficus nitida & Indian laurel & 5 \\
\hline 56 & Parkinsonia aculeata & Jerusalem thorn & 2 \\
\hline 57 & Litchii chinensis & Litchii nut & 2 \\
\hline 58 & Cocos australis & Pindo palm & 11 \\
\hline 59 & Lawsonia inermis & Camphire of solomon & 6 \\
\hline 60 & Acacia dealbata & Silver wattle & 8 \\
\hline 61 & Mangifera indica & Haden mango & 3 \\
\hline 62 & Nerium oleander & Pink \& white & 55 \\
\hline 63 & Lantana delicatissima & Creeping lantana & 310 \\
\hline 64 & Michelia fuscata & Banana shrub & 21 \\
\hline 65 & Acacia macracantha & Giant acacia & 25 \\
\hline 66 & Jasminum primulinum & Primrose jasmine & 266 \\
\hline 67 & Carica papaya & Pawpaw & 12 \\
\hline 68 & Acacia podalyriaefolia & Pearl acacia & 30 \\
\hline 69 & Citrus limonia & Ponderosa lemon & 1 \\
\hline 70 & Ficus macrophylla & Moreton bay fig & 1 \\
\hline 71 & Citrus nobilis & King orange & 1 \\
\hline 72 & Citrus nobilis unshiu & Dwarf satsuma orange & 1 \\
\hline 73 & Citrus nobilis deliciosa & Mandarin orange & 1 \\
\hline 74 & Wedelia trilobata & Creeping daisy & 375 \\
\hline 75 & Ligustrum iwata & Variegated privet & 72 \\
\hline 76 & Ligustrum lucidum & Glossy privet & 51 \\
\hline 77 & Severinia buxifolia & Chinese box orange & 80 \\
\hline 78 & Viburnum suspensum & Viburnum, sandankwa & 54 \\
\hline 79 & Ilex vomitoria & Yaupon holly & 32 \\
\hline 80 & Viburnum odoratissimum & Viburnum, sweet & 8 \\
\hline 81 & Camellia japonica & Double pink & 14 \\
\hline 82 & Camellia japonica & Semidouble rose & 1 \\
\hline 83 & Camellia japonica & Double white & 1 \\
\hline 84 & Yucca aloifolia & Spanish dagger & 141 \\
\hline
\end{tabular}




\begin{tabular}{|c|c|c|c|}
\hline \# & LATIN NAME & COMMON NAME & QTY \\
\hline 85 & Agave dech.pens & Century plant & 1 \\
\hline 86 & Agave neglecta & Blue century plant & 35 \\
\hline 87 & Furcrea lindeni & Stripped century plant & 4 \\
\hline 88 & Pandanus utilis & Screw pine & 2 \\
\hline 89 & Photinia serrulata & Photinia & 2 \\
\hline 90 & Rhapidophyllum hystrix & Needle palm & 50 \\
\hline 91 & Cestrum nocturnum & Night-blooming jessamine & 4 \\
\hline 92 & Cupressus arizonica oblonga & Weeping cypress & 1 \\
\hline 93 & Cupressus sempervirens stricta & Royal italian cypress & 1 \\
\hline 94 & Podocarpos macrophylla & Yew podocarpus & 3 \\
\hline 95 & Bouganvillea crimson lake & Red bouganvillea & 5 \\
\hline 96 & Agave americana variegata & Stripped century plant & 19 \\
\hline 97 & Agave miradorensis & Dwarf century plant & 6 \\
\hline 98 & Jasminum grandiflorum & Catalonian jasmine & 5 \\
\hline 99 & Alsophila australis & Australian treefern & 2 \\
\hline 100 & Cycas revoluta & Sago & 2 \\
\hline 101 & Illicium vernum & Anise shrub & 4 \\
\hline 102 & Ilex cassine & Danoon (holly) & 23 \\
\hline 103 & Eugenia uniflora & Surinam cherry & 363 \\
\hline 104 & Pittosporum tobira & Pittosporum & 57 \\
\hline 105 & Ficus repens & Creeping fig & 26 \\
\hline 106 & Rosa laevigata & Cherokee rose & 9 \\
\hline 107 & Tetrapanax papyriferum & Ricepaper plant & 8 \\
\hline 108 & Nerium oleander atropurpureum & Plenum red oleander & 3 \\
\hline 109 & Myrica cerifera & Wax myrtle & 696 \\
\hline 110 & Bignonia venusta & Flame vine & 19 \\
\hline 111 & Thunbergia grandiflora & Bengal clockvine & 6 \\
\hline 112 & Trachelosperum jasminoides & Confed. jasmine & 4 \\
\hline 113 & Ficus pandurata & Fiddleleaf fig & 2 \\
\hline 114 & Verbena erinoides & Moss vervain & 200 \\
\hline 115 & Serissa foetida & Serissa & 46 \\
\hline 116 & Dendrocalamus latiflorus & Giant bamboo & 1 \\
\hline 117 & Rhodomyrtus tormentosa & Downy myrtle & 34 \\
\hline 118 & Chayota edulis & Chayote & 1 \\
\hline 119 & Acacia floribunda & Golden wattle & 6 \\
\hline 120 & Chalcas exotica & Orange jasmine & 6 \\
\hline 121 & Hibiscus rosa-sinensis & Peachblow hibiscus & 10 \\
\hline 122 & Nerium oleander $d r$ golfin & Serese oleander & 11 \\
\hline 123 & Verbena beaty of oxford & Serese verbena & 50 \\
\hline 124 & Vaccinium myrcinites & Dwarf blueberry & 1355 \\
\hline 125 & Ilex glabra & Gallberry & 2190 \\
\hline 126 & Sabal palmetto & Cabbage palm & 89 \\
\hline 127 & Phoenix sylvestris & Indian date palm & 4 \\
\hline 128 & Eugenia myrtifolia & Austr. brush cherry & 5 \\
\hline
\end{tabular}




\begin{tabular}{|c|c|c|c|}
\hline \# & LATIN NAME & COMMON NAME & QTY \\
\hline 129 & Magnolia grandiflora & Southern magnolia & 8 \\
\hline 130 & Rosa odorata - h.t. & Hybrid tea rose & 12 \\
\hline 131 & Cudrania javanioa & Thorn of java & 6 \\
\hline 132 & Pyracantha angustifolia & Narrowleaf firethorn & 1 \\
\hline 133 & Pyracantha grenulata & Nepal firethorn & 10 \\
\hline 134 & Cotoneaster pannosa & Silver cotoneaster & 22 \\
\hline 135 & Bacharis halimifolia & Saltbush & 94 \\
\hline 136 & Azalea indica mixed & Indian azalea & 218 \\
\hline 137 & Psidium cattleyanum & Clattleia guava & 46 \\
\hline 138 & Strobilanthes anisophylis & Zigzag conehead & 34 \\
\hline 139 & Persea americana & Seedling avocado & 1 \\
\hline 140 & Jacaranda mimodaefolia & Jacaranda & 5 \\
\hline 141 & Sanseviera zeylonica & Bowstring hemp & 50 \\
\hline 142 & Phoenix rupicola & Cliff date palm & 1 \\
\hline 143 & Juniperus virginiana & Red cedar & 15 \\
\hline 144 & Zanthoxylum fagare & Wild lime & 20 \\
\hline 145 & Poinsettia pulcherrima & Red poinsettia & 15 \\
\hline 146 & Poinsettia pulcherrima & Pink poinsettia & 5 \\
\hline 147 & Itea virginica & Washington plume & 110 \\
\hline 148 & Cortalaria usaromiensis & Crotalaria & 100 \\
\hline 149 & Yucca filamentosa & Beargrass & 40 \\
\hline 150 & Azalea indica formosa & Lavender azalea & 25 \\
\hline 151 & Pittosporum undulatum & Orange pittosporum & 19 \\
\hline 152 & Bouganvillea glabra sanderiana & Purpple bouganvillea & 2 \\
\hline 153 & Pittosporum viridiflorum & Cape pittosporum & 7 \\
\hline 154 & Callistemon rigidus & Bottlebrush & 10 \\
\hline 155 & Azalea indica alba & White azalea & 68 \\
\hline 156 & Datura arborea & Floripondio & 4 \\
\hline 157 & Pittosporum rhombifolium & Tree pittosporum & 3 \\
\hline 158 & Acacia farnesiana & Sweet acacia & 5 \\
\hline 159 & Agave sisalana & Sisal & 8 \\
\hline 160 & washingtonia robusta & Mex. washington palm & 5 \\
\hline 161 & Phoenix canariensis & Canary island date palm & 2 \\
\hline 162 & Vallaris heynei & Burma vallaris & 1 \\
\hline 163 & Acrocomia total & Spine palm & 1 \\
\hline 164 & Bauhinia purpurea alba & White mt. ebony & 7 \\
\hline 165 & Tristania conferta & Brisbane box & 3 \\
\hline 166 & Callistemon phoeniceus & Rose bottlebrush & 1 \\
\hline 167 & Bambusa thouarsi & Giant bamboo & 9 \\
\hline 168 & Bambusa argentea & Silver bamboo & 11 \\
\hline 169 & Lonicera sempervirens & Coral honeysuckle & 31 \\
\hline 170 & Cyperus alternifolius & Umbrella sedge & 5 \\
\hline 171 & Cyperus papyrus & Papyrus & 3 \\
\hline 172 & Sarrasena minor & Hooded pitcher plant & 20 \\
\hline
\end{tabular}




\begin{tabular}{lllr}
$\#$ & LATIN NAME & COMMON NAME & QTY \\
\hline 173 & Sanseviera laurentii & Stripped bowstring hemp & 3 \\
174 & Iris hexagona & Native iris & 25 \\
175 & Cordonia lasianthus & Loblolly bay & 35 \\
176 & Rapanea guayanesis & Myrsine & 19 \\
177 & Magnolia glauca & Sweetbay & 10 \\
178 & Amaryllis hybrida & Meade hybrid amarillis & 42 \\
179 & Zamia integrifolia & Coontie & 12 \\
180 & Acrostichum vulgare & Leatherfern & 6 \\
181 & Panicum palmifolium & Palm grass & 50 \\
182 & Vinca rosea & Periwinkle & 50 \\
183 & Hibiscus rosa-sinensis & Single pink hibiscus & 4 \\
184 & Feijoa sellowiana & Pineapple guava & 16 \\
185 & Allamanda nerifolia & Oleander allamanda & 36 \\
186 & Callistemon salignus & Green bottlebrush & 3 \\
187 & Cycas circinalis & Queen sago & 1 \\
188 & Ficus rubiginosa & Rusty fig & 1
\end{tabular}




\section{APPENDIX C}

Plant List by Susan Gammons 2001

\begin{tabular}{lll} 
& COMMON NAME & LATIN BINOMIAL NAME \\
\hline 1 & African iris & Dietes iridioides (syn. D vegeta) \\
2 & Algerian ivy & Hedera canariensis \\
3 & Argyranthemum & Argyranthemum frutescens 'Butterfly' \\
4 & Asparagus fern & Asparagus densiflorus 'Sprengeri' \\
5 & Australian brush_cherry* & Eugenia. myrtifolia 'Globulus' \\
6 & Azalea & Rhododendron sp. 'Formosa' \\
7 & Azalea & Rhododendron sp. 'George Franc' \\
8 & Azalea & Rhododendron sp. 'Miyo_No_Sakae' \\
9 & Azalea & Rhododendron sp. 'Salmon. Solomon' \\
10 & Baby rubber plant & Peperomia obtusifolia \\
11 & Banana shrub & Michelia fuscata \\
12 & Beauty berry & Callicarpa americana \\
13 & Bird of paradise & Strelitzia reginae \\
14 & Bird's nest fern & Asplenium nidus \\
15 & Blackberry lily & Belamcanda chinensis \\
16 & Blood_flower & Asclepias curassavica \\
17 & Blue sage & Eranthemum pulchellum \\
18 & Blue salvia & Salvia guaranitica \\
19 & Boxwood & Buxus microphylla \\
20 & Bush daisy & Gamolepis crysanthemoides \\
21 & Butterflybush & Buddlei officinalis \\
22 & Butterfly ginger & Hedychium coronarium \\
23 & Cabbage palm & Sabal palmetto \\
24 & Calamandarin & Citrus reticulata hybrid \\
25 & Calla lily & Zantedeschia aethiopica \\
26 & Camellia & Camellia japonica \\
27 & Camellia & Camellia sasanqua \\
28 & Camphor tree & Cinnamomum camphora \\
29 & Cape honeysuckle & Tecomaria capensis \\
30 & Cape marigold & Osteospernum sp. \\
31 & Caribbean agave & Agave augustifolia 'Marginata' \\
32 & Century plant & Agave americana \\
33 & Cherry laurel & Prunus caroliniana \\
34 & Chinese box orange & Severinia buxifolia \\
35 & Chinese fan palm. & Livistona chinensis \\
36 & Chinese witchhazel & Loropetalum chinense \\
37 & Coontie & Zamia pumila \\
38 & Coral berry & Ardisia crenata \\
39 & Creeping daisy & Wedelia trilobata \\
40 & Creeping fig & \\
& & Ficws reps \\
&
\end{tabular}




\begin{tabular}{|c|c|c|}
\hline 41 & Crape myrtle & Lagerstroemia indica \\
\hline 42 & Crossandra & Crossandra infundibuliformis \\
\hline 43 & Croton & Codiaeum variegatum var, pidum \\
\hline 44 & Cypress pine & Callitris verrucosa \\
\hline 45 & Cypress pine & Callitris glaucophylla \\
\hline 46 & Cypress pine & Callitris columellaris \\
\hline 47 & Date palm, canary island & Phoenix Canariensis \\
\hline 48 & Date palm, pygmy & Phoenix roebelenii \\
\hline 49 & Date palm, senegal & Phoenix reclinata \\
\hline 50 & Dracaena* & Dracaena marginata \\
\hline 51 & Dwarf palmetto & Sabal minor \\
\hline 52 & Eastern red cedar & Juniperus virginiana \\
\hline 53 & Egyptian papyrus & Cyperus papyrus \\
\hline 54 & Erect sword fern & Nephrolepis cordifolia \\
\hline 55 & Eucalyptis tree & Eucalyptis sp. \\
\hline 56 & Eurya hedge & Eurya emarginata \\
\hline 57 & False blue ginger & Dichorisandra tbyrsiflora \\
\hline 58 & Firecracker plant & Russelia equisetiformis \\
\hline 59 & Firebush & Hamelia patens \\
\hline 60 & Flame vine & Pyrostegia venusta \\
\hline 61 & Florida anise tree & Illicium floridanum \\
\hline 62 & Florida jujube & Zizyphus celata \\
\hline 63 & Flowering dogwood & Cornus florida \\
\hline 64 & Giant bird of paradise & Strelizia nicolai \\
\hline 65 & Golden candles & Pachystachys lutea \\
\hline 66 & Golden dewdrop & Duranta repens \\
\hline 67 & Grapefruit & Citrus x Paradisi 'Ruby Red' \\
\hline 68 & Grugru palm & Acrocomia Total \\
\hline 69 & Hardy bamboo palm* & Chamaedorea miemspadix \\
\hline 70 & Hayscented fern & Dennstaedtia punctilobula \\
\hline 71 & Heavenly bamboo & Nandina domestica \\
\hline 72 & Inca lily & Alstroemeria pulchella \\
\hline 73 & Japanese mock orange & Pittosporum tobira \\
\hline 74 & Japanese plum yew & Cephalotaxus harryingtonia \\
\hline 75 & Jasmine, carolina yellow & Gelsemium sempervirens \\
\hline 76 & Fern & Blechnum sp. \\
\hline 77 & Jasmine, downy & Jasminum multiflorum \\
\hline 78 & Jasmine, primrose & Jasminum mesnyi \\
\hline 79 & Laurel oak & Quercus laurifolia \\
\hline 80 & Leatherleaf fern & Rumohra adiantiformis \\
\hline 81 & Lemon tree & Citrus limon \\
\hline 82 & Lily of the nile & Agapanthus africanus \\
\hline 83 & Pink allamanda & Mandevillea splendens \\
\hline 84 & Live oak & Quercus virginiana \\
\hline
\end{tabular}




\begin{tabular}{|c|c|c|}
\hline 85 & Living vase & Aechmea 'Little Harry' \\
\hline 86 & Long-leaf pine & Pinus palustris \\
\hline 87 & Loquat & Eriobotrya japonica \\
\hline 88 & Macaw palm & Acrocomia aculeata \\
\hline 89 & Majesty palm* & Ravenea rivularis \\
\hline 90 & Mandarin's hat & Holmskioldia sanguinea \\
\hline 91 & Mexican flame vine & Senecio confusus \\
\hline 92 & Mickey mouse plant & Ochna multiflora \\
\hline 93 & Mondo grass & Ophiopogon japonicus \\
\hline 94 & Nagami kumquat & Fortunella margarita \\
\hline 95 & Needle palm & Rhapidophyllum hystrix \\
\hline 96 & Orange tree & Citrus sinensis \\
\hline 97 & Papaya & Carica papaya \\
\hline 98 & Paulownia & Paulownia fortune $i$ \\
\hline 99 & Peace lily & Spathyphyllum 'Mauna Loa' \\
\hline 100 & Pentas & Pentas lanceolata \\
\hline 101 & Pindo palm & Butia capitata \\
\hline 102 & Plumbago & Plumbago auriculata \\
\hline 103 & Ponytail* & Beaucarnea recurvata \\
\hline 104 & Privet, japanese & Ligustrum japonica \\
\hline 105 & Pumelo & Cifrus grandis 'Hirado Bantan' \\
\hline 106 & Queen palm & Syagrus romanzoffiana \\
\hline 107 & River birch & Betula nigra 'Heritage' \\
\hline 108 & Sago, king & Cycas revoluta \\
\hline 109 & Sago & Cycas hybrid \\
\hline 110 & Sago, queen & Cycas circinalis \\
\hline 111 & Saw palmetto & Serenoa repens \\
\hline 112 & Sentry palm* & Howea forsteriana \\
\hline 113 & Simpson's stopper & Myrcianthes fragans \\
\hline 114 & Snake plant, variegated* & Sansevieria trifadciata 'Laurentii' \\
\hline 115 & Sour orange & Citrus aurantium \\
\hline 116 & Louisiana iris & Iris 'Louisiana Hybrids' \\
\hline 117 & Southern magnolia & Magnolia grandiflora \\
\hline 118 & Southern magnolia & Magnolia grandiflora 'Hasse' \\
\hline 119 & Southern wax myrtle & Myrica cerifera \\
\hline 120 & Spanish moss & Tillandsia usneoides \\
\hline 121 & Split-leaf philodendron* & Philodendron bipinnatifidum \\
\hline 122 & St. christopher lily & Crinum jagus \\
\hline 123 & Strawberry guava & Psidium littorale (syn.P. cattleinum) \\
\hline 124 & Surinam cherry & Eugenia uniflora \\
\hline 125 & Tangelo & Citrus reticulata hybrid 'Orlando' \\
\hline 126 & Tangerine & Citrus reticulata 'Sunburst Carizzo' \\
\hline 127 & Tea olive & Osmanthus fragans \\
\hline 128 & Tea olive, florida & Osmanthus americana \\
\hline
\end{tabular}


129 Umbrella sedge

130 Variegated pineapple*

131 Spanish bayonet

132 Variegated spanish bayonet

133 Viburnum, sandankwa

134 Viburnum, sweet

135 Wandering jew

136 Wax mallow, pink form

137 Widespread maidenhair fern

138 Wild coffee

139 Yaupon holly

140 Yaupon holly, columnar

141 Yaupon holly, weeping

142 Yellow brazilian plume

143 Yellow flax

144 Yellow salvia

145 Yew podocarpus

146 White azalea

147 Red azalea

148 Pink azalea

149 Crinum

150 Orchid tree

151 Orange tree

152 Yesterday, today, \& tomorrow

153 American holly

154 Silver dollar tree

155 Pearl acacia

156 Cape jasmine
Cyperus alternifolius

Ananas bracteatus 'Tricolor'

Yucca aloifofia

Yucca aloifolia 'Marginata'

Viburnum suspensum

Viburnum odoratissimum

Tradescantia zebrina

Malvaviscus arboreus var. mexicanus

Thelypteris kunthii

Psychotria nervosa

Ilex vomitoria

Ilex vomitoria 'Will Fleming'

Ilex vomitoria 'Pendula'

Justicia aurea

Reinwardtia indica

Salvia madrensis

Podocarpus macrophyllus

Rhododendron sp.

Rhododendron $s p$.

Rhododendron sp.

Crinum sp.

Bauhinia variegata

Citrus sinensis 'Parson Brown'

Brunfelsia pauciflora

Ilex opaca

Eucalyptis cinerea

Acacia podarylifolia

Tabernaemontana divaricata 


\section{APPENDIX D}

List of plans and drawings of Olsmted Job \# 6023 - C. A. Bbuck/Pinewood Estate/El Retiro, Mountain Lake, Florida, located at Frederick L. Olmsted National Historic Site, Brookline, Massachussetts

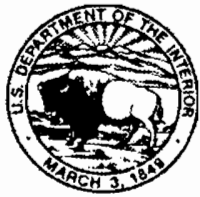

IN REALY REFER TO.

\section{United States Department of the Interior}

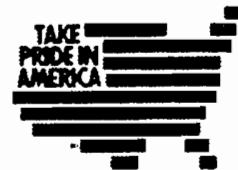

Frederick Law Olmsted National Historic Site

99 Warren Street

Brookline, Massachusetts 02445

December 6, 2000

H 18

Olmsted Job \#6023 C.A. Buck/Pinewood Estate/El Retiro Mountain Lake, Florida

Elizabeth Baron

$11100 \mathrm{SW} 67^{\mathrm{th}}$ Avenue

Miami, FL, 33156

Dear Ms. Baron:

In response to your telephone call of July 18 , the archives staff searched the historic office records of the Olmsted firm for information relating to Olmsted Job \#6023 C.A. Buck Mountain Lake, Florida. Listed below are documents included in the Olmsted Archives for Olmsted Job \#6023.

\section{Olmsted Job \#6023 C.A. Buck/Pinewood Estate Mountain Lake, Florida} 22 plans and drawings, 1929-1931

1 file folders of Post-1949 correspondence, 1929-1970

I photograph album including approximately 34 historic prints, 1930-1932

As we discussed on the telephone, the bulk of the Olmsted firm's correspondence predating 1950 was donated by the Olmsted firm to the Manuscripts Division of the Library of Congress in Washington, D.C. Enclosed is a brief description of the Olmsted Papers and Olmsted Associates Records at LC. You may wish to see if any related papers exist at LC. The telephone number is (202) 707-5387.

The correspondence between the Olmsted firm and the client is often critical in clarifying the design intent and the extent of work which was carried out by the firm. Based on past experience, many researchers have found the correspondence invaluable in terms of explaining the nature of the firm's work.

Enclosed is an Olmsted Archives Access Policy for you to review. Researchers need to submit requests for appointments in writing. If you need further assistance 
please feel free to contact the archives staff at (617) $566-1689 \times 231$ or $\times 241$. Best wishes with your research.

Sincerely,

T. Michele Clark

Archivist

Enclosures: Olmsted Archives Access Policy

Olmsted Archives and Site Brochures

LC Guide to Olmsted Papers

Plans inventory for job \#6023 (6 sheets) 
nowar

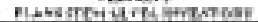

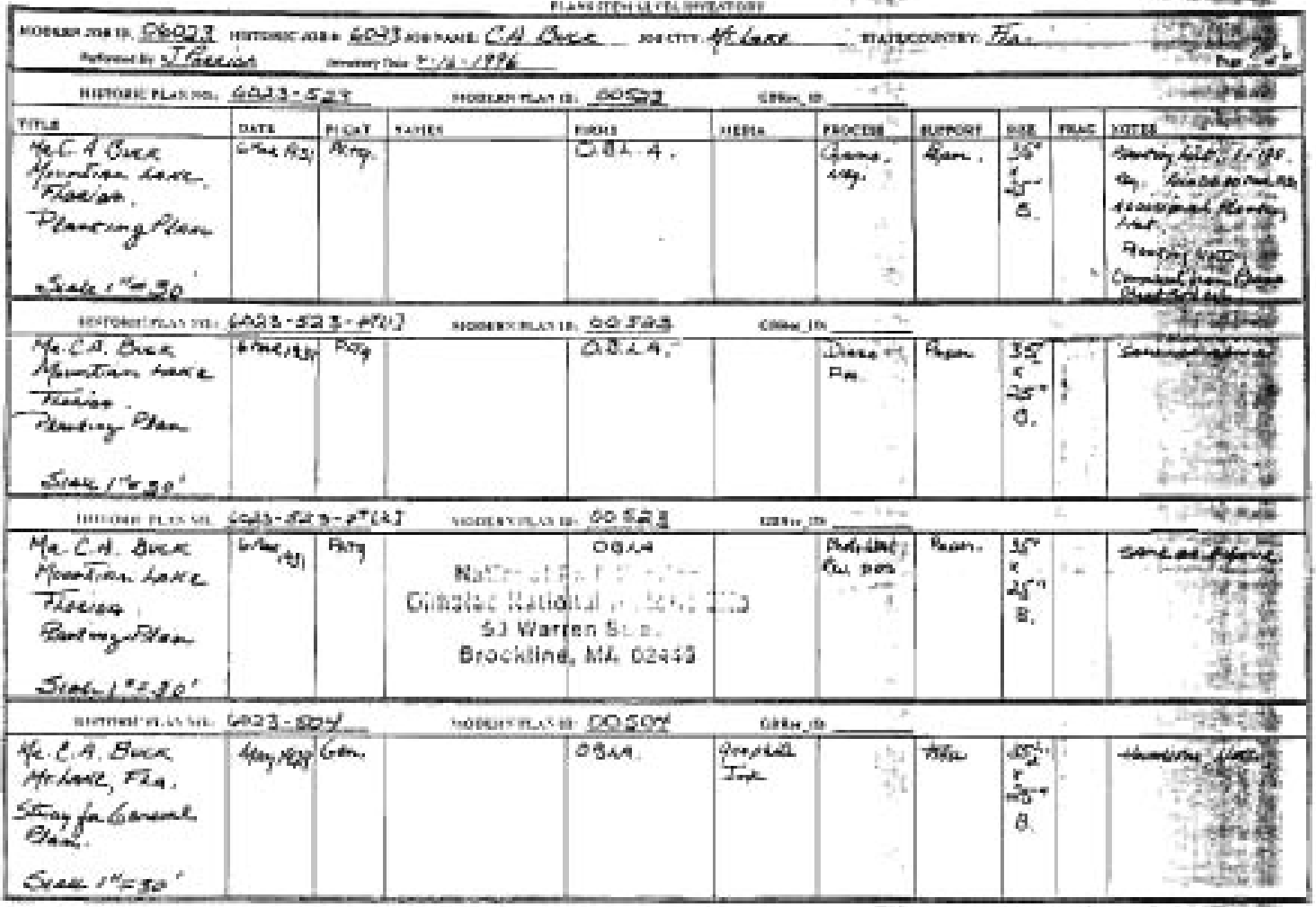

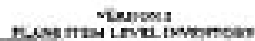

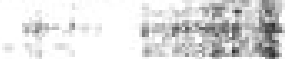

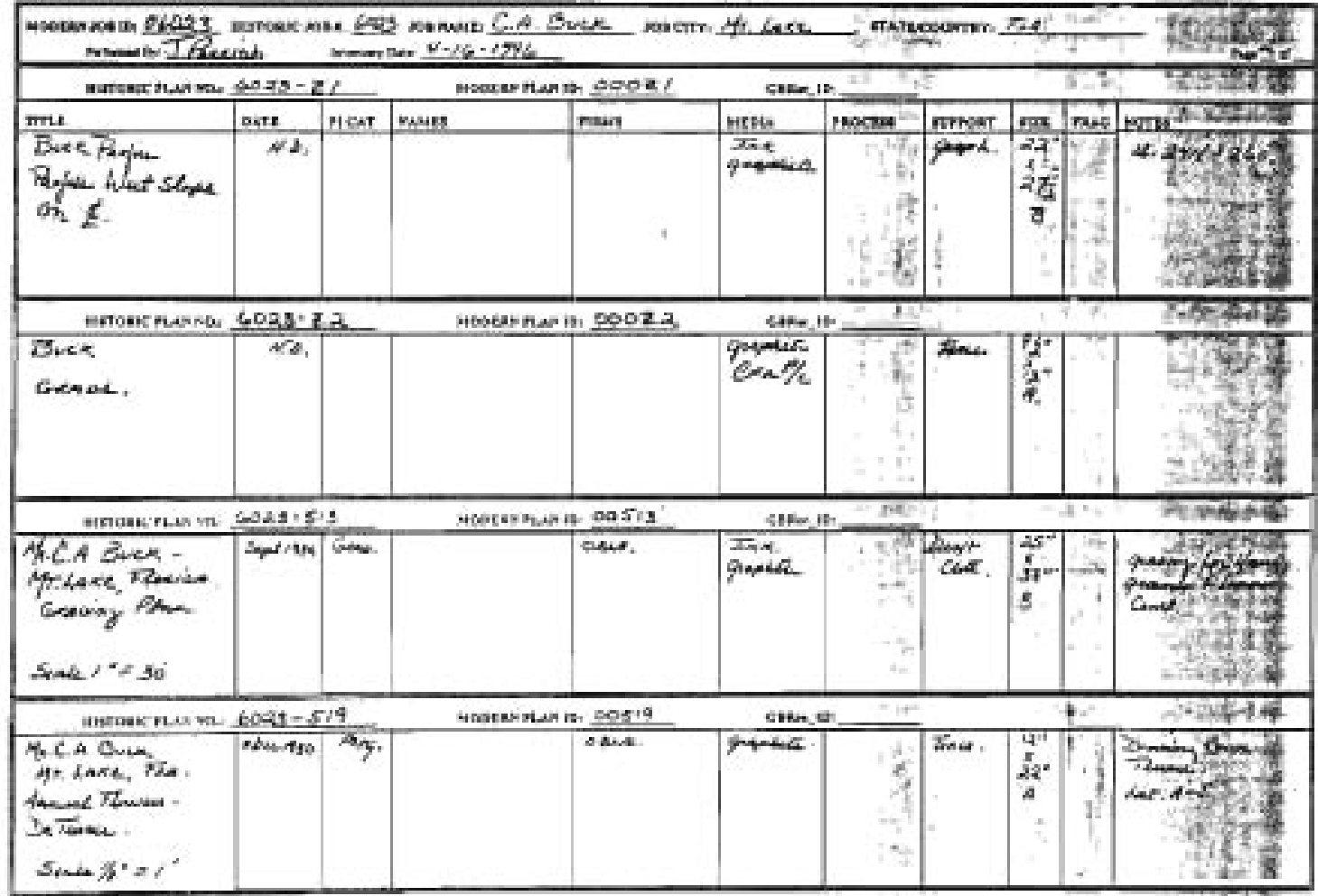


vashov:

MoNgitruLEVL inzorroar

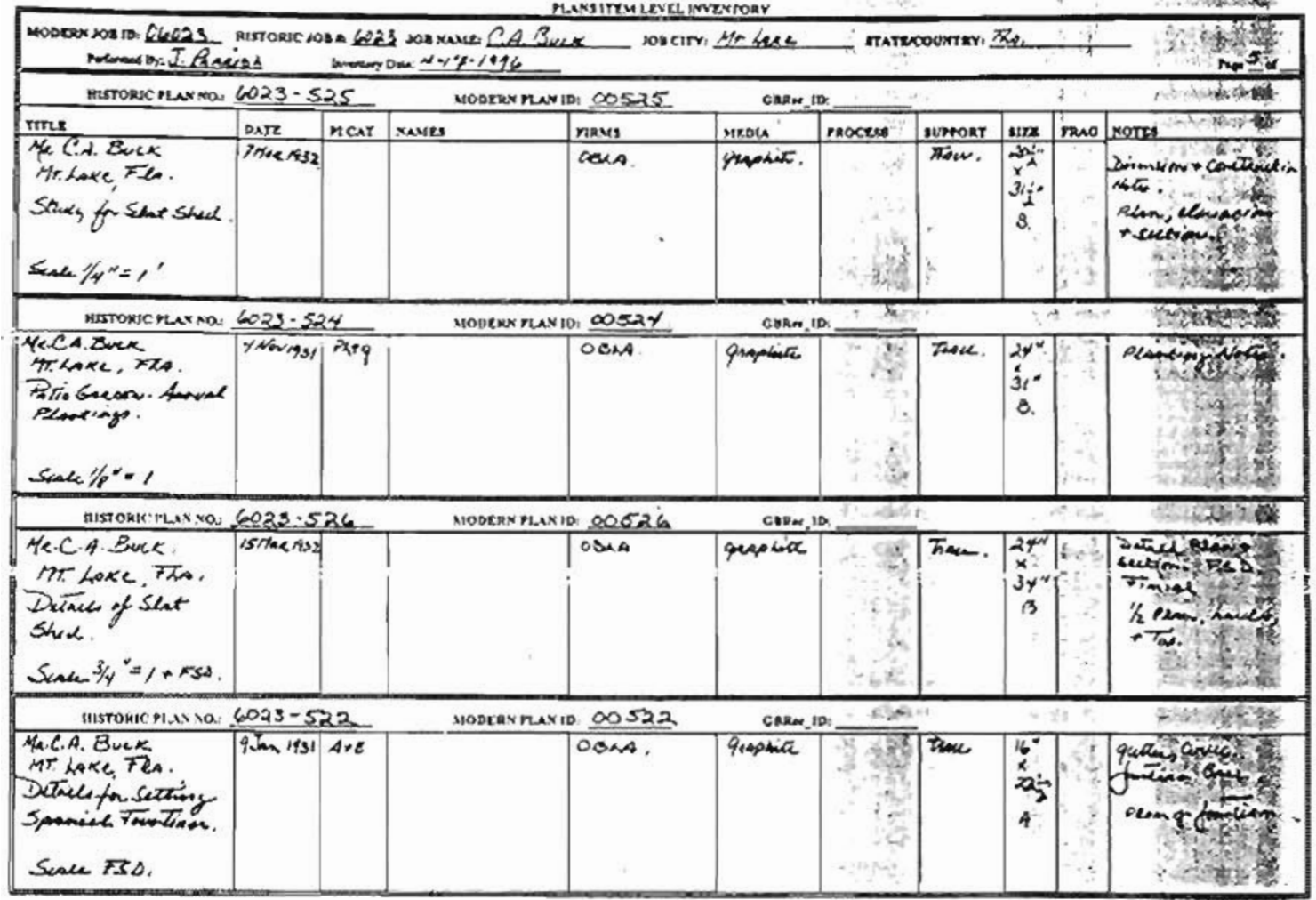

vesiber 2

\begin{tabular}{|c|c|c|c|c|c|c|c|c|c|c|}
\hline Modenerrosia: 06023 & $\begin{array}{l}\text { nistonc bo: } \\
\text { eish }\end{array}$ & a. $\log 2$ & $\begin{array}{l}3 \text { soo kum: } \\
\text { Doer } y-z=1\end{array}$ & ck & of: baxe & marex & covintarn & 24 & $\frac{3 x: 2}{x+2}$ & 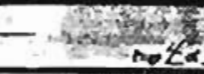 \\
\hline mistosenarna. & $6023-5$ & 15 & soo & 10,00515 & $\cos 20 x_{-}$ & a. & & 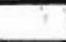 & i & 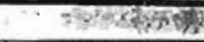 \\
\hline $\min x$ & DATE & nCAT & vaMizs & nous & MEDL & reacess 4 & currokt & stie & iruo & 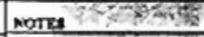 \\
\hline 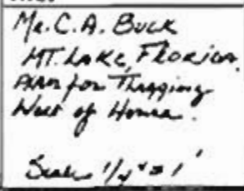 & Spet 1930 & trE & & OSA. & guoposiz & \begin{tabular}{|r|} 
\\
$7 y$ \\
3 \\
$z$ \\
$z$
\end{tabular} & दisece. & $\mid \begin{array}{l}2 y^{\prime \prime} \\
x \\
73 y+4 \\
2 .\end{array}$ & $\begin{array}{l}i \\
-8 \\
-2\end{array}$ & 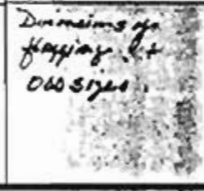 \\
\hline nistonic marno: & $6023-5$ & 511 & $M O D$ & 0.00511 & cures & $\mathrm{Dn}_{4}$ & & & & 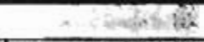 \\
\hline 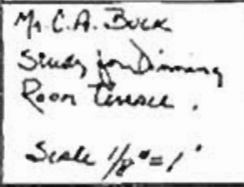 & Wsent: & 6200. & Promun. & $\cos A$ & gineluata. & $\frac{3}{3}+\frac{1}{3}$ & hioue & $\begin{array}{c}16^{\prime \prime} \\
x^{\prime \prime} \\
7 r_{2}^{\prime} \\
A\end{array}$ & 3 & 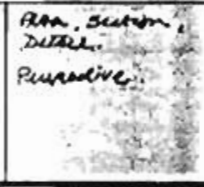 \\
\hline uxroak nusvo: & $60023 \cdot 5$ & 514 & 2100 & 10.005i4 & cukes & $0.7+2$ & & & & \\
\hline 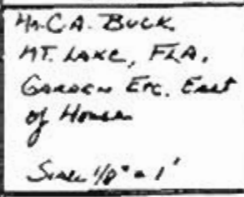 & 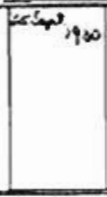 & Ane & & osin. & graperace. & $\begin{array}{r}+28 \\
+28 \\
4 \\
4 \\
4\end{array}$ & There & $\begin{array}{l}2 k^{\prime} \\
1 \\
35 \\
0 .\end{array}$ & 7 & 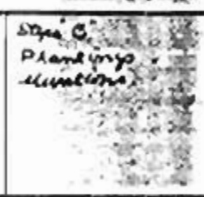 \\
\hline urstomk n,WNO: & $6023-z$ & & MOD & - 0023 & Gaver: & a. & & & & 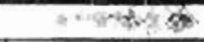 \\
\hline $\begin{array}{l}\text { Buce. } \\
\text { Hower Psoms } \\
\text { Siak } 1 / p^{\prime \prime}=1\end{array}$ & NO. & & & $\begin{array}{ll}2+2 \\
\end{array}$ & 9unptick & $\begin{array}{r}35 \\
4 \\
4 \\
3 \\
3 \\
3\end{array}$ & Take. & $\begin{array}{l}15 \\
35= \\
35\end{array}$ & 3 & 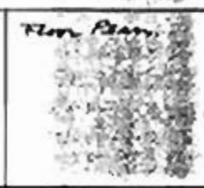 \\
\hline
\end{tabular}


visuon?

ture mrou Levec averrogr

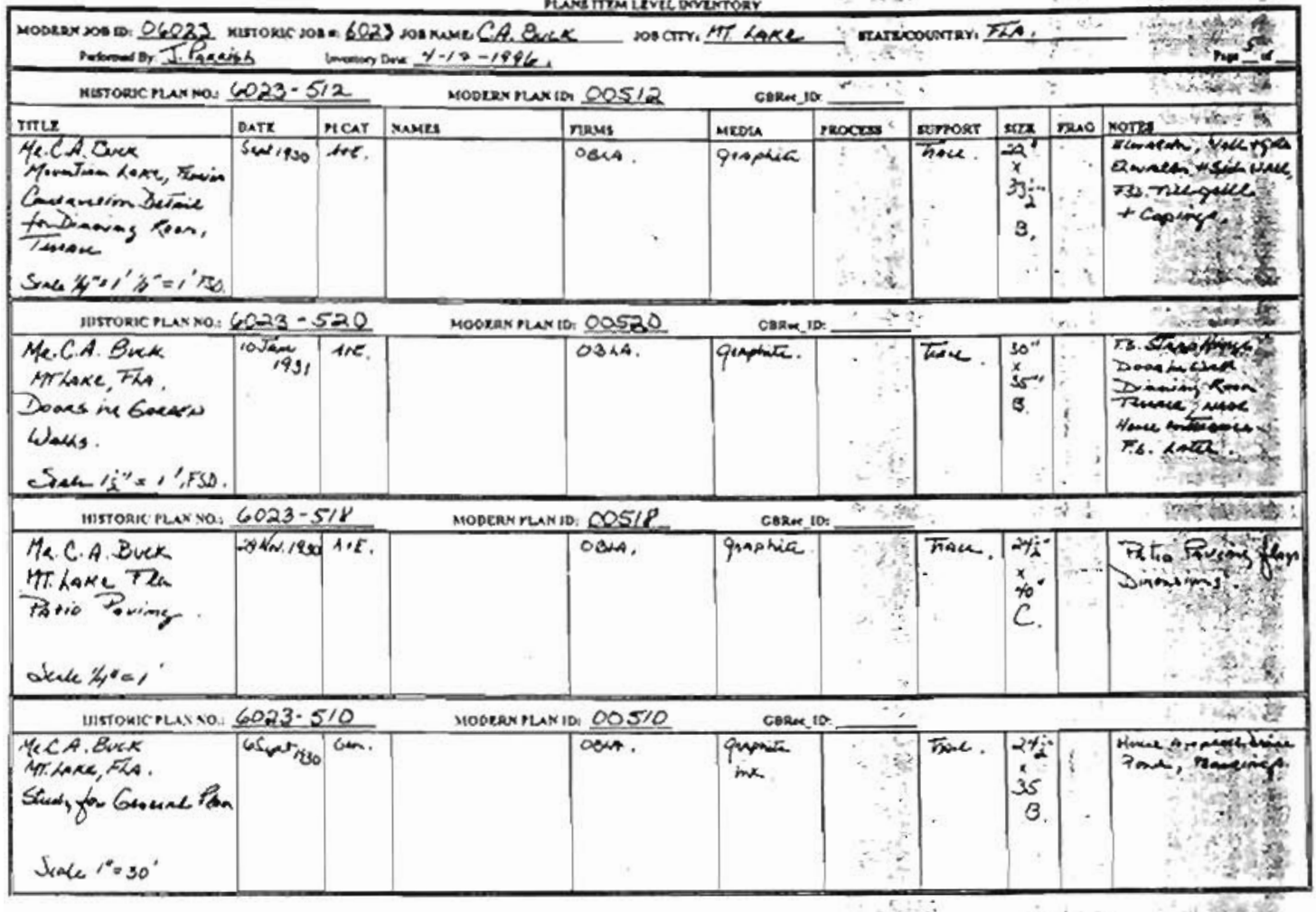

Vex:ON?

NUMA TTEU LEVTL DEVETORY

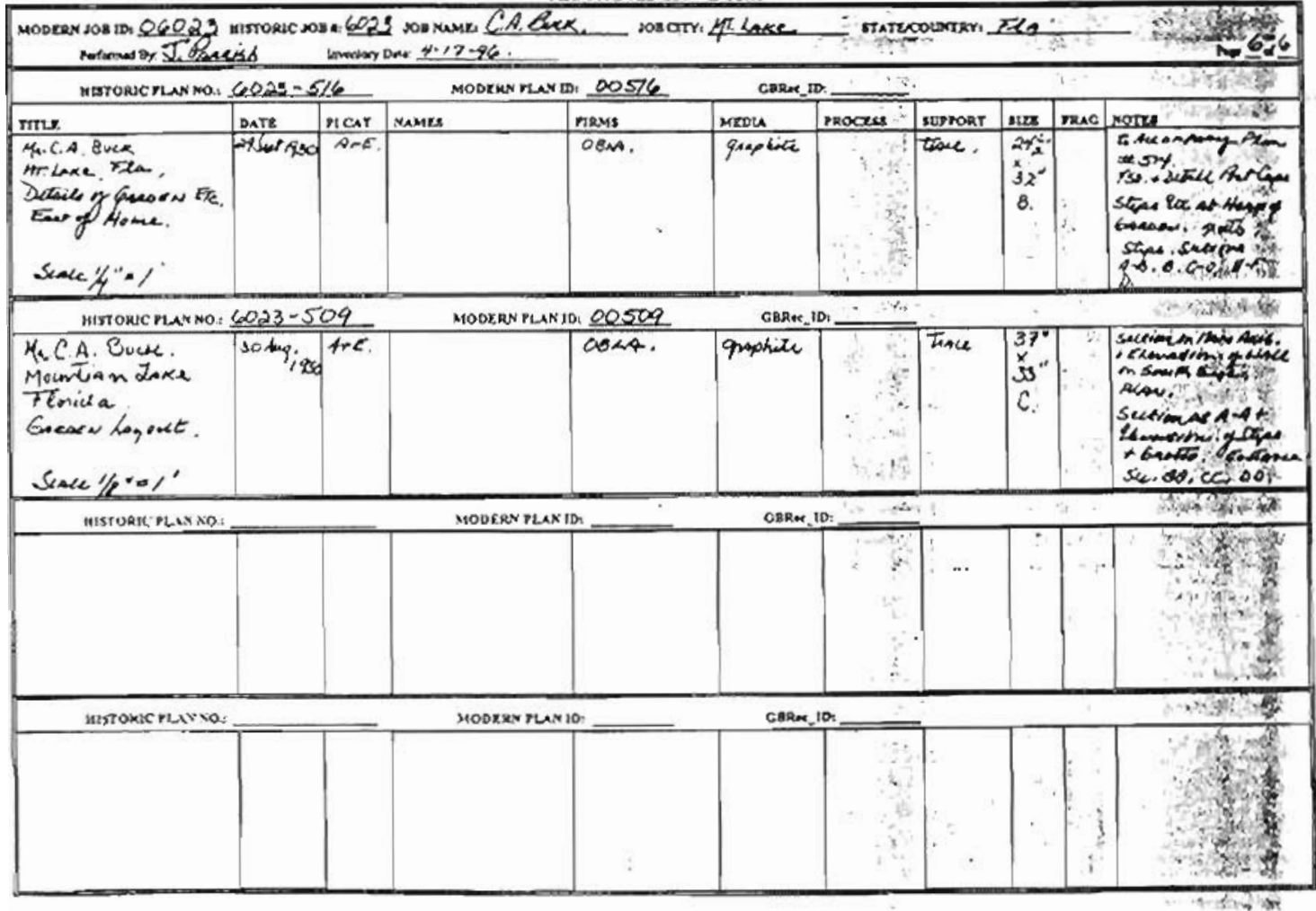




\section{APPENDIX E}

Documents for Pinewood House and Garden, located at the Historical Association of Southern Florida, Miami Florida

Phillips, William Lyman, 1885-1966

Papers, 1886-1992

17.25 linear feet.

Gift of Juliette Phillips Coyle, through Faith Jackson, 1994

\begin{tabular}{|l|l|l|}
\hline Medium & Accesion Number & Location \\
\hline Papers & $1994-335$ & M42C-G \\
\hline Photographs and Negatives & $1994-753-1$ thru 365 & Photos: M42C; 5x7 Negs.: M87C \\
\hline Notebooks & $1994-790-1$ thru 3 & M42B \\
\hline Drawings and Certificate & $1994-791-1$ thru 3 & $\begin{array}{l}\text { M76H Oversized Ephemera-Box } \\
2\end{array}$ \\
\hline Plans & $1994-788-1$ thru 128 & $\begin{array}{l}\text { R4X, Y, Z, AA, BB [Blueprints } \\
\text { in separate folder] }\end{array}$ \\
\hline Maps & $1994-796-1$ thru 27 & R4AA; R4X [Blueprint] \\
\hline
\end{tabular}

\section{Biographical Note}

Landscape architect William Lyman Phillips is the best know for his work in Florida during the 1920s to 1950s. his projects included bok Tower (Lake Wales), Crandon Park (Key Biscayne), Fairchild Tropical Garden (Coral Gables), Matheson Hammock (Miami), and Mountain Lake Sanctuary (Lake Wales).

Phillips received his master's degree in landscape architecture from Harvard. Ha studied under Frederick Law Olmsted, and worked under him on the design of the Biltmore estate grounds, Asheville, N.C.

In 1915, he designed the towns of Balboa and Pedro Miguel in the Panama Canal Zone. After World War I he assisted in the design of American military cemeteries in France. He worked at Mountian lake Sanctuary and Bok Tower in the 1920s. in 1933 he moved to Miami, and designed parks and supervised their construction for the Civilian Conservation Corps-Greynolds Park, Bakers Haulover, Matheson Hammock, etc. from 1938 until his retirement in 1954, he worked at Fairchild Tropical Garden, first as part of a CCC project, than as the garden's landscape architect.

Phillips died October 18, 11966, in North Miami.

For more biographical information, refer to:

Phillips, W.L. The Fairchild Tropical Garden: a Memoir. 1959.

Zuckerman, Bertram. The Dream Lives On: A History of the Fairchild Troopical Garden, 19338-1988. Miami: Banyan books, 1988. 


\section{Scope and Content}

The bulk of the collection contains papers that pertain to W. L. Phillips' career, from his work at Harvard University in the early 1900s to his involvement in numerous landscaping projects through the late 1950 s, with substantial portions of this data relating to the Mountain Lake Sanctuary and the Royal Palm State Park. Among the records are letters, invoices, notes, clippings, sketches, reports, planting lists, specifications, photographic prints, negatives, pamphlets, and ephemera. Documents related to professional organizations and awards are also included. A set of alphabetized index cards bean notes concerning landscape architecture, astronomy, investment information, property data, and other topics. In addition, notebooks of Harvard class notes, classified plant lists, and field notes and sketches augment the collection. Supplementing the papers regarding professional projects are original plans and blueprints, as well as several maps. Where indicated in the files, photocopies of some plans substitute for the originals which are located at the University of Miami.

Also maintained in the collection are papers documenting Phillips' personal life spanning the early 1900 s to the mid-1960s. Correspondence with family members and friends, school records and notebooks, an address book, birth and death records, passports, identification cards, certificates, travel brochures, clippings, and other ephemera comprise this material. Financial and property records include bank statements, correspondence, mortgage papers, investment documents, and tax information. In addition, the personal data contains a 1992 historic designation report for Phillips' North Miami residence. Two pencil drawings found among the papers depict the figure of an unknown youth and a signed portrait of William Lyman Phillips.

The collection is arranged into eleven series: residential projects (private); residential projects (commercial); commercial projects; professional correspondence; professional papers; clippings; personal correspondence; personal papers; financial and property records; photographic prints; and plans and maps, Within each series, files possess an alphabetical order by subject followed by a chronological arrangement where dates are indicated.

Phillips' landscape drawings (blueprint) are at the University of Miami library, Special Collections Department, and may be used by appointment.

Special Collections

Otto G. Richter Library

University of Miami

P. O. Box 248214

Coral Gables, Florida 33124

(305) 284-3247 
Phillips papers and related materials, particularly relating to Fairchild Tropical Garden, are housed at the garden's research facility, and may be used by appointment.
Archives
Fairchild tropical Garden
11935 Old Cutler Road
Miami, Florida 33156
(305) 665-2844 